UNIVERSIDADE DE SÃO PAULO

FACULDADE DE ECONOMIA, ADMINISTRAÇÃO E CONTABILIDADE DE RIBEIRÃO PRETO

DEPARTAMENTO DE CONTABILIDADE

\title{
O IMPACTO DOS ESTILOS DE APRENDIZAGEM NO ENSINO DE CONTABILIDADE NA FEA-RP/USP
}

DENISE MENDES DA SILVA

Orientador: Prof. Dr. José Dutra de Oliveira Neto

Ribeirão Preto 
Reitora da Universidade de São Paulo:

Profa. Dra. Suely Vilela

Diretor da Faculdade de Economia, Administração e Contabilidade de Ribeirão Preto:

Prof. Dr. Rudinei Toneto Júnior

Chefe do Departamento de Contabilidade:

Profa. Dra. Maisa de Souza Ribeiro 


\section{O IMPACTO DOS ESTILOS DE APRENDIZAGEM NO ENSINO DE CONTABILIDADE NA FEA-RP/USP}

Dissertação apresentada ao Departamento de Contabilidade da Faculdade de Economia, Administração e Contabilidade de Ribeirão Preto da Universidade de São Paulo, como parte dos requisitos para obtenção do título de Mestre em Controladoria e Contabilidade.

Área de Concentração: Controladoria e Contabilidade Orientador: Prof. Dr. José Dutra de Oliveira Neto 


\section{FICHA CATALOGRÁFICA}

Silva, Denise Mendes da.

O impacto dos Estilos de Aprendizagem no ensino de Contabilidade na FEA-RP/USP.

Ribeirão Preto, 2006.

169 p. : il. ; $30 \mathrm{~cm}$

Dissertação de Mestrado apresentada à Faculdade de Economia, Administração e Contabilidade de Ribeirão Preto/USP Área de concentração: Controladoria e Contabilidade.

Orientador: Oliveira Neto, José Dutra de.

1. Contabilidade - Estudo e Ensino. 2. Ensino Superior. 3. Estilo Cognitivo 


\section{FOLHA DE APROVAÇÃO}

Denise Mendes da Silva

O impacto dos Estilos de Aprendizagem no ensino de Contabilidade na FEA-RP/USP.

Dissertação apresentada ao Departamento de Contabilidade da Faculdade de Economia, Administração e Contabilidade de Ribeirão Preto da Universidade de São Paulo, como parte dos requisitos para obtenção do título de Mestre em Controladoria e Contabilidade.

Área de Concentração: Controladoria e Contabilidade

Aprovada em:

Banca Examinadora

Prof. Dr. José Dutra de Oliveira Neto

Instituição: FEA-RP/USP

Assinatura:

Prof. Dr.

Instituição:

Assinatura:

Prof. Dr.

Instituição: Assinatura: 


\section{DEDICATÓRIA}

Ao meu pai, Vicente, minha eterna gratidão, por nunca ter poupado esforços para me ajudar em todos os momentos da vida. 


\section{AGRADECIMENTOS}

À Faculdade de Economia, Administração e Contabilidade de Ribeirão Preto (FEA-RP/USP), pela oportunidade de realização do curso de Mestrado e dessa pesquisa.

Ao Prof. Dr. José Dutra de Oliveira Neto, meu orientador, pela dedicação e paciência.

A todos os professores do curso de Mestrado em Controladoria e Contabilidade da FEA-RP, pelas experiências e conhecimentos transmitidos e, em especial, ao Prof. Dr. Silvio Hiroshi Nakao, pela consideração demonstrada em um momento particularmente difícil da minha vida.

Ao Prof. Dr. Evandro Marcos Saidel Ribeiro, pela disponibilidade em ajudar e toda a atenção.

Ao Prof. Dr. Renato Vairo Belhot e ao Prof. Dr. Reginaldo Santana Figueiredo, membros da banca examinadora, pelas considerações feitas a respeito do trabalho e por autorizar o uso do questionário eletrônico para mapeamento dos estilos de aprendizagem.

Aos colegas da primeira turma de Mestrado em Controladoria e Contabilidade da FEA-RP, pelo apoio, carinho e auxílio.

A todos os alunos e professores do curso de graduação em Contabilidade da FEA-RP, que contribuíram para a realização desse trabalho, respondendo aos questionários.

À Valéria Degani Furlani, da seção de graduação, e aos funcionários da seção de informática da FEA-RP, pelas informações fornecidas.

À Profa. Dra. Edna Maria Campanhol pela amizade e apoio constante.

Aos meus familiares, colegas e amigos. 
"A vida está cheia de desafios que, se aproveitados de forma criativa, transformam-se em oportunidades." 


\section{RESUMO}

SILVA, D. M. da. O impacto dos Estilos de Aprendizagem no ensino de Contabilidade na FEA-RP/USP. 2006. 169 p. Dissertação (Mestrado). Faculdade de Economia, Administração e Contabilidade de Ribeirão Preto, Universidade de São Paulo, Ribeirão Preto, 2006.

Esse estudo tem como objetivo principal avaliar o impacto dos estilos de aprendizagem dos alunos, professores e disciplinas no desempenho acadêmico dos alunos do curso de graduação em Contabilidade da Faculdade de Economia, Administração e Contabilidade de Ribeirão Preto - Universidade de São Paulo (FEA-RP/USP). Para identificação dos estilos de aprendizagem foi utilizado o Índice de Estilos de Aprendizagem de Felder-Soloman (ILS), questionário on-line, acessível na página eletrônica da Escola de Engenharia de São Carlos Universidade de São Paulo (EESC/USP). Participaram da pesquisa, 194 alunos do curso de graduação em Contabilidade da FEA-RP, o que corresponde a $82 \%$ dos alunos ativos do curso, e 29 professores que, além do ILS, responderam um outro questionário, elaborado pelos pesquisadores, com base no Modelo de Felder-Silverman, para identificação dos estilos de 40 disciplinas do curso. $\mathrm{O}$ desempenho acadêmico dos alunos foi mensurado pelas médias finais das notas obtidas por eles, antes das reavaliações, critério este escolhido, em termos de precisão metodológica, como forma de tornar a pesquisa direcionada e objetiva. Os resultados mostraram que os estilos dominantes dos alunos são: ativo, sensorial, visual e seqüencial. A maioria dos professores tem estilos reflexivo, intuitivo, visual e seqüencial e a maioria das disciplinas é reflexiva, sensorial, verbal e seqüencial. Foi constatado o impacto dos diferentes estilos de aprendizagem desses elementos no desempenho acadêmico dos alunos, tanto individualmente, como combinados, revelando, para algumas dimensões, médias significativamente mais altas.

Palavras-chave: Ensino de Contabilidade. Ensino Superior. Estilo de Aprendizagem. 


\begin{abstract}
SILVA, D. M. da. The impact of Learning Styles in Accounting Education at FEARP/USP. 2006. 169 p. Dissertation (Mastership). School of Economics, Business and Accounting of Ribeirão Preto, University of São Paulo, Ribeirão Preto, 2006.

This study has as main objective to evaluate the impact of student, teacher and class learning styles in under graduate academic performance in the Accounting course of the School of Economics, Business and Accounting of Ribeirão Preto - University of São Paulo (FEARP/USP). For identification of learning styles it was used the Felder-Soloman's Index of Learning Styles (ILS), on-line questionnaire, accessible on the electronic page of the School of Engineering of São Carlos University of São Paulo (EESC/USP). It has participated of the research, 194 students of the FEA-RP Accounting course, which corresponds to $82 \%$ of the active students of the course, and 29 teachers who, beyond the ILS, had answered one another questionnaire, elaborated by researchers, on the basis of the Felder-Silverman's Model, for identification of the styles of course's 40 classes. The student's academic performance was measured for the final grades gotten by them, before the reevaluations, criterion chosen, in terms of methodological precision, as a form to have the research direct and objective. The results show that the student's dominant styles are: active, sensorial, visual and sequential. Most of teachers is reflective, intuitive, visual and sequential and most of classes is reflective, sensorial, verbal and sequential. The impact of the different learning styles of these elements in the student's academic performance, such as individually and combined, disclosing was evidenced, for some dimensions, significantly better grades.
\end{abstract}

Keywords: Accounting Education. Higher Education. Learning Styles. 


\section{LISTA DE QUADROS}

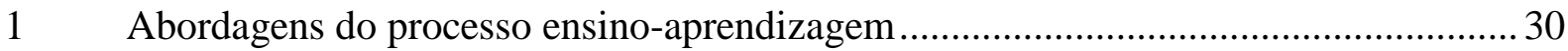

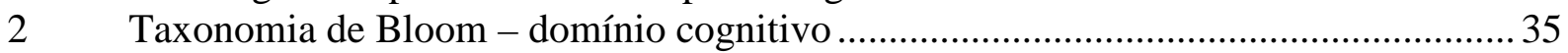

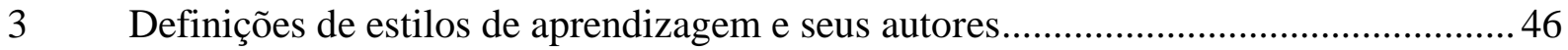

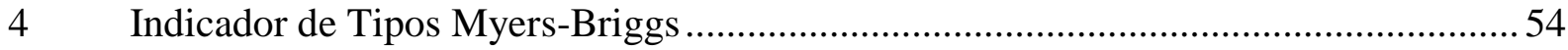

5 Dimensões dos estilos de aprendizagem e dos estilos de ensinar ...............................60

$6 \quad$ Classificação de acordo com o Índice de Estilos de Aprendizagem ............................62

7 Mestrados/Doutorados reconhecidos - grande área: Ciências Sociais Aplicadas ........ 87

8 Conteúdos obrigatórios propostos para os cursos de Ciências Contábeis ....................89

9 Conteúdos complementares propostos para os cursos de Ciências Contábeis ............. 90

10 Uma análise dos níveis de competências do professor ............................................... 93

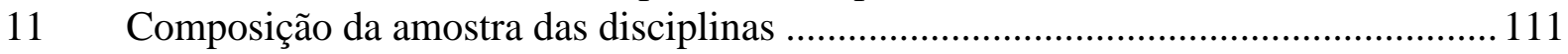

12 Estilos predominantes em cada elemento e combinações de maior média................... 134 


\section{LISTA DE GRÁFICOS}

1 Distribuição percentual dos estilos de aprendizagem dos alunos ............................. 118

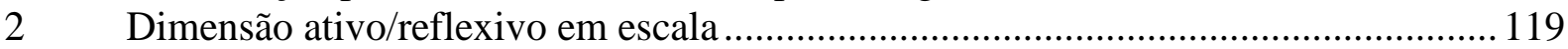

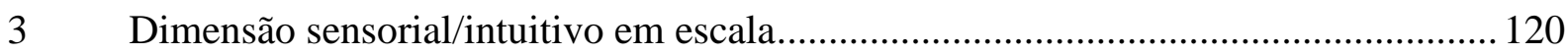

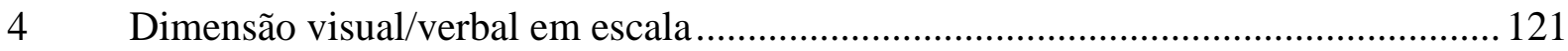

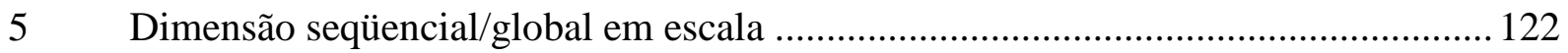

6 Distribuição percentual dos estilos de aprendizagem dos professores ....................... 124 


\section{LISTA DE TABELAS}

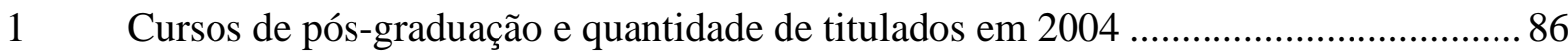

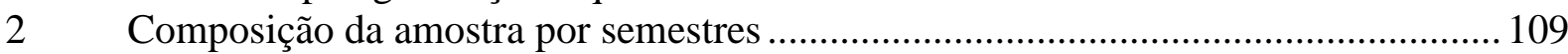

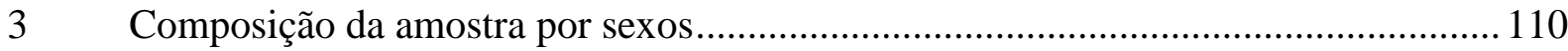

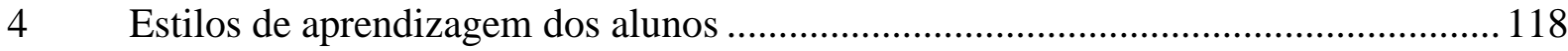

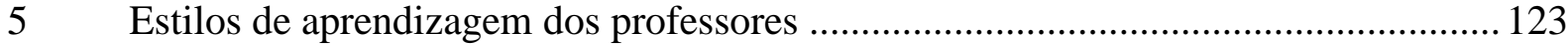

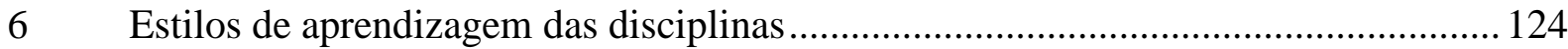

$7 \quad$ ANOVA multifatorial para dimensão ativo/reflexivo ............................................. 126

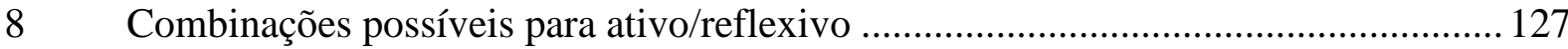

$9 \quad$ ANOVA multifatorial para dimensão sensorial/intuitivo ...................................... 128

10 Combinações possíveis para sensorial/intuitivo ........................................................ 129

11 ANOVA multifatorial para dimensão visual/verbal ............................................... 129

12 Interação entre disciplina e professor na dimensão visual/verbal ............................... 130

13 Combinações possíveis para visual/verbal ........................................................ 130

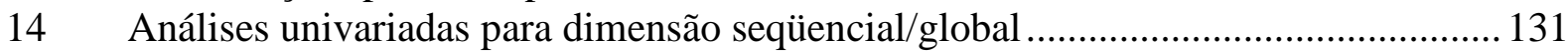

15 ANOVA multifatorial para dimensão seqüencial/global ...................................... 131

16 Combinações possíveis para seqüencial/global ..................................................... 132

17 Combinações de maiores e menores médias.............................................................. 133 


\section{SUMÁRIO}

1 INTRODUÇÃ

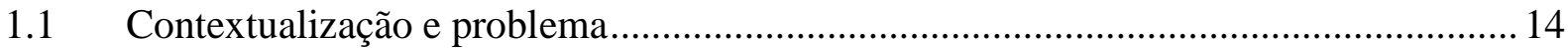

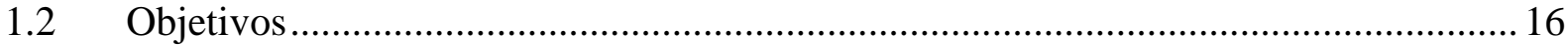

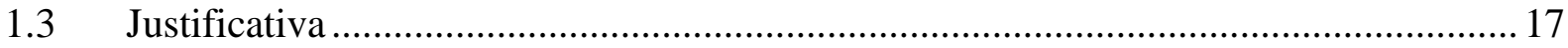

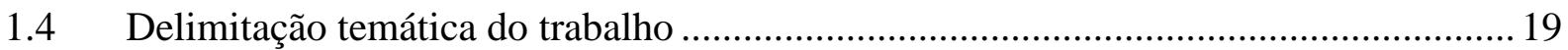

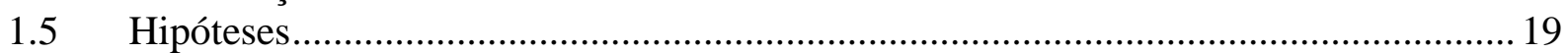

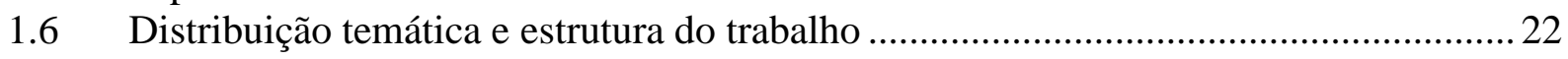

2 ENSINO, APRENDIZAGEM E ESTILOS DE APRENDIZAGEM ...................26

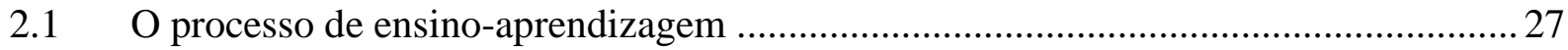

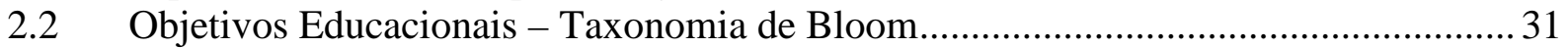

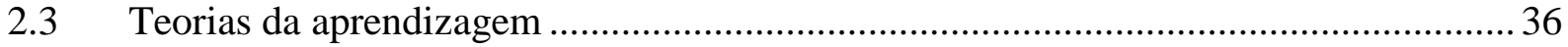

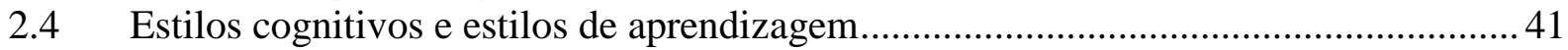

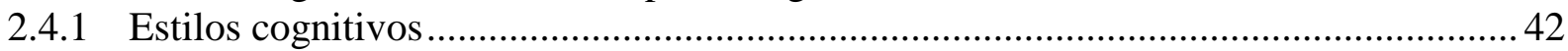

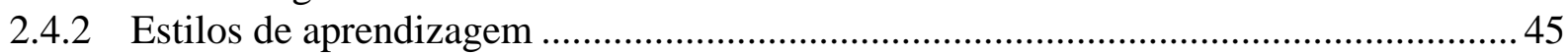

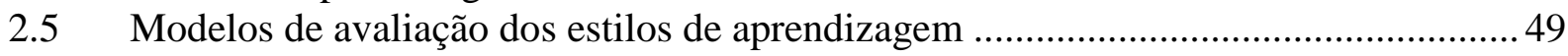

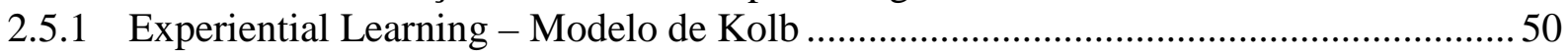

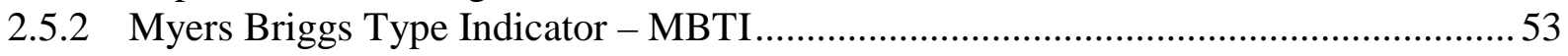

2.5.3 Modelo de Estilos de Aprendizagem de Felder-Silverman .........................................55

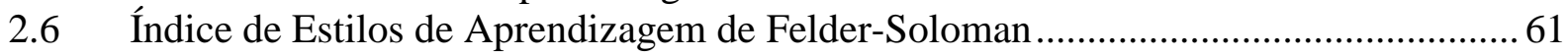

2.7 Estilos de aprendizagem e ensino de Contabilidade ....................................................66

$3 \quad$ ENSINO DE CONTABILIDADE .............................................................................. 72

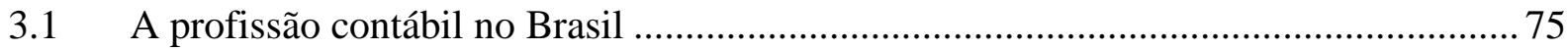

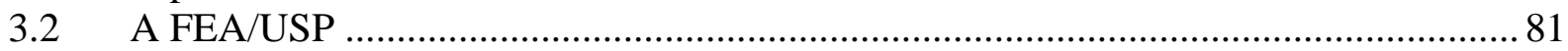

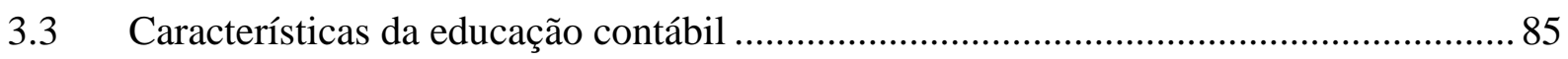

3.4 Competências e habilidades no ensino de Contabilidade ............................................ 91

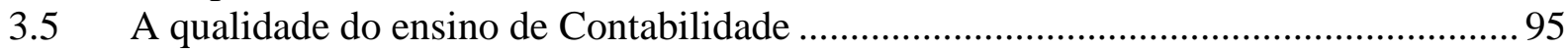

3.6 Metodologias didáticas aplicadas ao ensino de Contabilidade ................................... 98

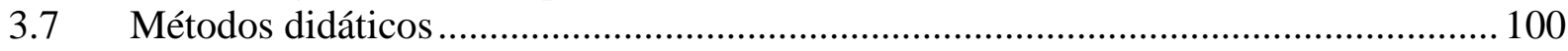

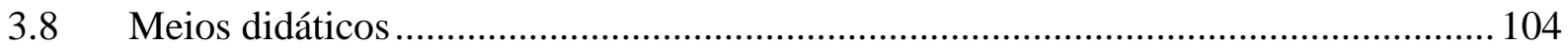

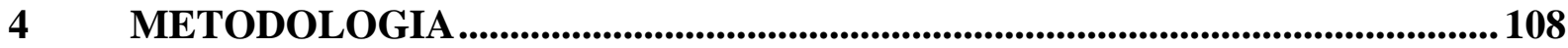

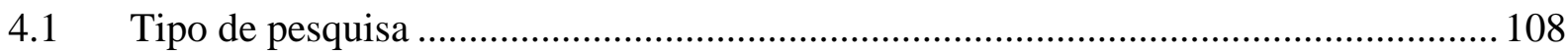

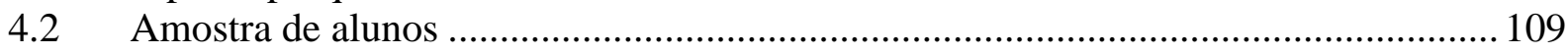

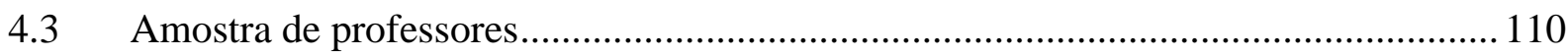

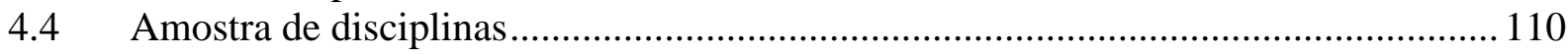

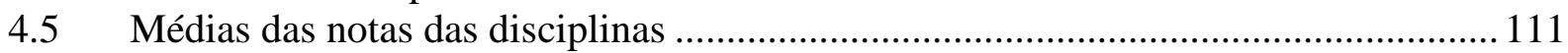

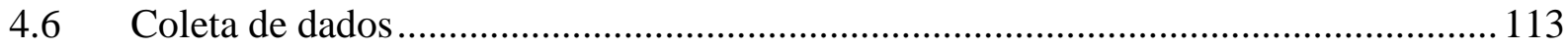

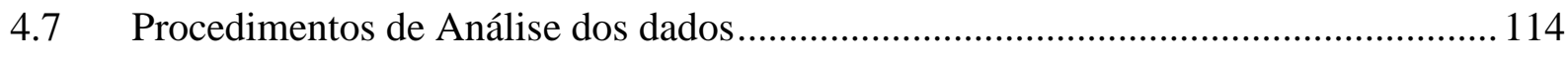

$5 \quad$ RESULTADOS E ANÁLISE DOS RESULTADOS ............................................. 117 


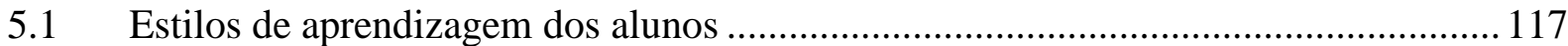

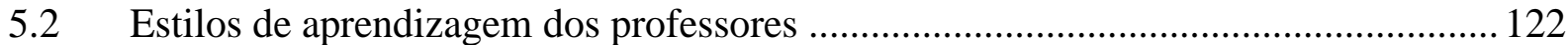

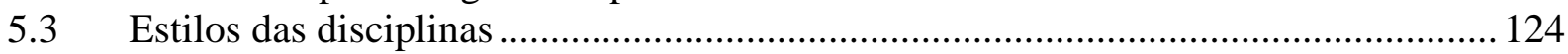

5.4 O impacto dos estilos de aprendizagem no desempenho acadêmico dos alunos........ 125

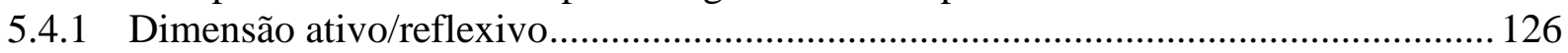

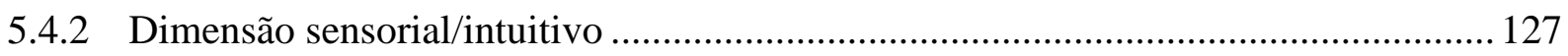

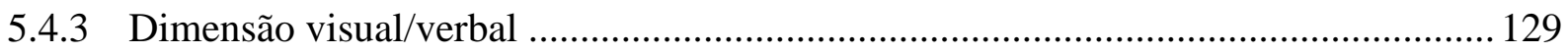

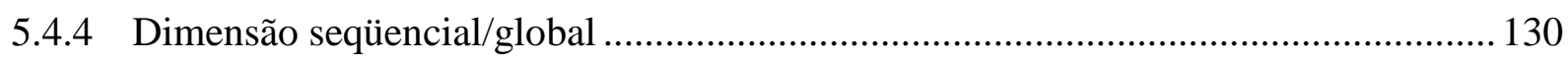

5.5 Análise geral dos resultados e estratégias de ensino e aprendizagem ........................ 132

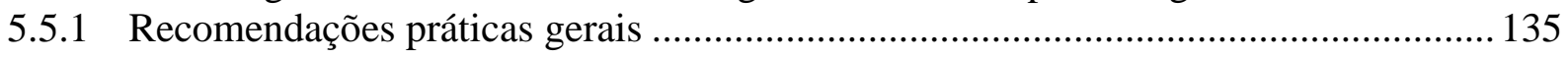

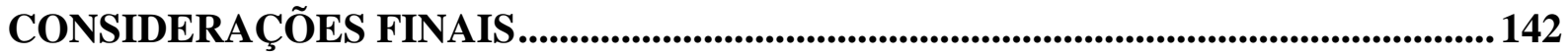

REFERÊNCIAS BIBLIOGRÁFICAS .......................................................................... 146

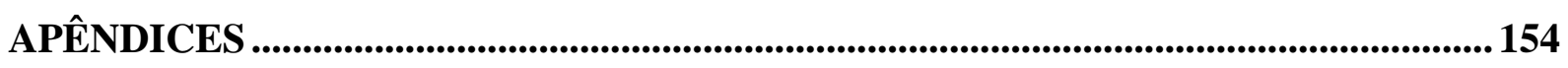

A - Disciplinas da grade curricular e seus objetivos .................................................. 155

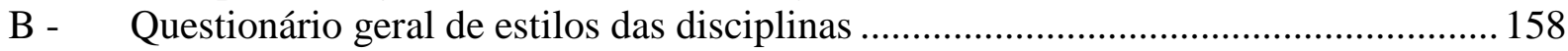

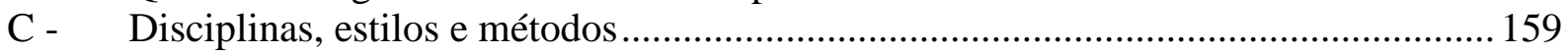

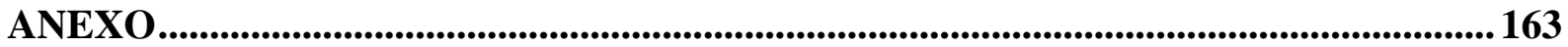

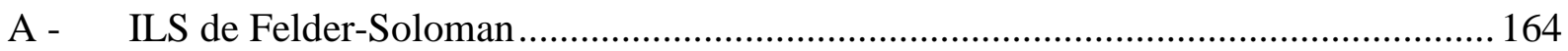




\section{INTRODUÇÃO}

Constantes mudanças vêm ocorrendo atualmente no processo do conhecimento, motivando novas formas de ensinar e aprender. A velocidade das informações e a evolução tecnológica fazem com que as necessidades pessoais e profissionais alterem-se substancialmente com o passar do tempo. Pode haver, muitas vezes, certo nível de tensão quando essas necessidades são atendidas inadequadamente ou permanecem insatisfeitas.

Os estudantes possuem pretensões pessoais e profissionais e, talvez, o que falte seja uma visão completa e profunda dos contextos e realidades à sua volta, uma postura ativa, não só de consciência profissional, mas também, uma reflexão de sua atitude no aprendizado.

Os professores, por sua vez, precisam reformular suas práticas, suas competências e, principalmente, seu saber, no sentido de atender, dentro da realidade em que estão inseridos, as necessidades dos envolvidos nas instituições de ensino e dar sua contribuição ao ambiente acadêmico.

O processo de ensino-aprendizagem é identificado como aquele em que há o envolvimento do aluno, instituição, assunto e professor. Sendo assim, tanto os professores e instituições de ensino, como os alunos, devem objetivar discutir e experimentar novas alternativas para aumento da eficácia e da eficiência desse processo.

Uma etapa inicial poderia ser a identificação das características e preferências particulares que as pessoas apresentam no processo de aprendizagem, ou seja, a identificação dos estilos de aprendizagem. Certamente, grande parte dos professores sabe que o ensino é mais eficaz quando são consideradas as diferenças individuais do que os alunos já conhecem, porém, eles precisam reconhecer a importância de saber como é que os alunos aprendem.

Na verdade, os profissionais do ensino não revelam muita familiaridade com o que se refere às diferenças individuais ou aos modos peculiares como cada indivíduo aprende, pois, 
não há, obrigatoriamente, na formação de educadores, uma área de estudo, matéria, disciplina ou mesmo atividade que promova a abordagem desse assunto. Isso se deve ao fato de o ensino ser focado no professor e não no aluno.

Conhecer os diferentes estilos de aprendizagem e, também, a forma de utilizá-los para alcançar os objetivos educacionais e de aprendizagem é relevante, tanto para os alunos, na medida em que possibilita o desenvolvimento de estratégias de aprendizagem, como para os professores, que podem aprimorar e diversificar seus métodos de ensino de acordo com as particularidades de suas turmas.

\subsection{Contextualização e problema}

Os estudos sobre estilos de aprendizagem foram desenvolvidos a partir de interesses nas diferenças individuais. Os estilos de pensar e aprender se propõem a explicar a forma como as pessoas percebem, processam e transformam a informação, ou seja, a maneira que elas interagem com as condições de aprendizagem.

Santos, Bariani e Cerqueira (2000), ressaltam que "há possibilidades de se tirar proveito educacional da avaliação dos estilos de pensar e aprender, tanto no sentido de se obter vantagens dos potenciais identificados, como no enfrentamento dos limites percebidos". Esses autores concluem, em seu trabalho, que a aprendizagem é algo construído, que as estratégias de aprender estão relacionadas ao estilo pessoal de cada um e que, para o professor ser capaz de auxiliar seus alunos, seria recomendável que nos cursos de formação de professores houvesse, no mínimo, uma introdução ao estudo da conceituação de estilos de aprendizagem, buscando prepará-los para conhecerem melhor seus alunos, bem como a si mesmos. 
Desse modo, o estilo de aprender é um conceito muito importante, também, para os professores, porque reflete em sua maneira de ensinar. Frequentemente um professor tende a ensinar como ele gostaria de aprender, ou seja, ensinar de acordo com seu próprio estilo de aprendizagem. Segundo Cerqueira (2000, p. 30) esse processo interno e inconsciente, na maioria dos professores, aflora e é analisado quando cada um deles tem a oportunidade de estudar e medir suas preferências de aprendizagem, que logo desembocam em preferências que modelariam o seu estilo de ensinar.

Essa situação pode ser aplicada a todos os anos de escolaridade, inclusive à etapa do ensino superior. Marion (2001, p. 127) diz que "o professor, independentemente da matéria a ser ensinada, deverá conhecer bem os alunos (seu público alvo) e, em função disto, variar os seus métodos de ensino". Conforme esse autor, dentro dos cursos de graduação em Ciências Contábeis constata-se grandes dificuldades na aplicação de métodos de ensino.

Desde a criação do curso superior de Contabilidade até hoje, nota-se um enorme crescimento. O curso de Ciências Contábeis recebe uma grande procura, estando, recentemente, entre os dez maiores cursos em número de matrículas e concluintes. Nesse contexto estão inseridas diversas instituições de ensino, dentre as quais se destaca a Faculdade de Economia, Administração e Contabilidade da Universidade de São Paulo, campus Ribeirão Preto (FEA-RP/USP), que completou, neste ano de 2006, 14 anos de existência, tendo adotado o modelo de ensino e aprendizagem de São Paulo, com suas tradições e competências.

Outro detalhe a ser analisado é o fato de que a existência de diversos estilos de aprendizagem e suas várias classificações e abordagens, o que poderá ser visto no desenvolvimento desse trabalho, levou pesquisadores de áreas como educação e psicologia a acumular tais estilos em categorias ou inventários. Surgiram, assim, os inventários dos estilos 
de aprendizagem ou learning styles inventories (LSI), instrumentos para avaliação desses estilos, tais como o de Kolb (1985), Myers-Briggs (1970), Felder-Soloman (1991) etc.

Considerando o exposto, o trabalho foi desenvolvido na FEA-RP/USP e se propõe a investigar como os diferentes estilos de aprendizagem estão distribuídos entre os alunos, professores e disciplinas do curso de graduação em Contabilidade, utilizando-se do Índice de Estilos de Aprendizagem de Felder-Soloman ( Felder Soloman's Index of Learning Styles ILS), traduzido para o português por Marcius F. Giorgetti e Nídia Pavan Kuri da Escola de Engenharia de São Carlos - Universidade de São Paulo - EESC/USP (ver anexo A). Também verifica a associação entre os estilos desses três elementos e o desempenho dos alunos nas disciplinas do curso, este mensurado pelas médias das notas obtidas nas avaliações.

Como conseqüência, a questão de pesquisa que se coloca é: Os estilos de aprendizagem dos alunos, professores e disciplinas impactam no desempenho acadêmico dos alunos do curso de graduação em Contabilidade da FEA-RP?

O estudo se apóia no fato de que o conhecimento dos estilos de aprendizagem ajuda na tomada de decisões de possíveis adequações do ensino ao estilo de aprender dos alunos, podendo ser utilizado para prever tipos de estratégias ou métodos de instrução mais efetivos a determinado aluno ou grupo de estudantes, além de permitir o desenvolvimento de estratégias de aprendizagem por parte dos alunos.

\subsection{Objetivos}

O objetivo principal desse estudo é avaliar o impacto dos estilos de aprendizagem dos alunos, professores e disciplinas no desempenho acadêmico dos alunos do curso de graduação em Contabilidade da FEA-RP. 
Para se alcançar o objetivo principal devem ser traçados objetivos específicos que correspondam aos aspectos particulares dos fenômenos que se pretende estudar. Logo, como objetivos específicos da pesquisa têm-se:

1. Identificar os estilos de aprendizagem dos pilares do ensino de Contabilidade - alunos, professores e disciplinas - de acordo com o Índice de Estilos de Aprendizagem de Felder-Soloman;

2. Coletar o desempenho dos alunos nas disciplinas;

3. Avaliar o impacto dos estilos de aprendizagem no desempenho acadêmico dos alunos. Sendo assim, o trabalho pretende contribuir para as discussões e experiências já realizadas sobre o tema e para futuras pesquisas.

\subsection{Justificativa}

No ambiente educacional pode-se notar que existem grupos de pessoas com características semelhantes cujos canais de percepção e processamento de informação não são os mesmos. Isso significa que os indivíduos têm diferentes estilos de aprendizagem, ou seja, preferências nas maneiras de perceber e processar informações.

Alguns aprendizes tendem a se concentrar mais em fatos, datas e algoritmos. Outros se sentem melhor com teorias e modelos matemáticos. Existem aqueles que preferem informações de forma visual, por meio de figuras, diagramas e esquemas e aqueles que preferem informações na forma verbal. Existem, ainda, alunos que preferem aprender participando ativamente e interativamente e outros que são mais introspectivos.

Desse modo, é comum surgir, entre os professores, questionamentos relacionados à qual seria a melhor forma de se trabalhar na construção dos conhecimentos e quais 
metodologias ou estratégias de ensino seriam mais eficazes para determinadas turmas de alunos.

De forma geral, as informações são transmitidas de várias maneiras e, muitas vezes, são perdidas por falta de se conhecer e explorar melhor esses estilos. Se os professores ensinam exclusivamente para um ou outro estilo, os estudantes com estilos diferentes se sentirão incomodados e poderão não obter desempenho satisfatório.

O fato de se conhecer o estilo de aprendizagem do aluno não reflete a sua adequação ou inadequação para uma determinada disciplina, curso ou profissão, mas ajuda a melhorar a aprendizagem na medida em que o professor propõe não só atividades que vão de encontro ao estilo preferencial de suas turmas, como também, a escolha de métodos instrutivos que desafiem outros estilos, a fim de estimular e fortalecer as dimensões menos desenvolvidas.

No processo de ensino-aprendizagem o professor é a pessoa capaz de determinar se seus alunos irão atingir os objetivos educacionais ou não. Conhecendo bem os seus alunos, o professor conseguirá identificar qual o método ou o conjunto de métodos que poderão ser aplicados no processo para proporcionar melhores desempenhos.

Por sua vez, quando os alunos têm conhecimento dos estilos dos professores e das disciplinas que irão cursar, podem se prevenir quanto a estratégias de aprendizagem que eventualmente terão que adotar para garantir um bom desempenho.

Sendo assim, a realização desse estudo se justifica por permitir analisar as possibilidades de adaptação dos métodos de ensino como forma de respeito à individualidade de quem aprende.

Sua importância reside na crença de que, uma vez mais bem entendidos os elementos fundamentais do processo de ensino-aprendizagem - aluno, professor e disciplina direcionamentos individuais e ou institucionais possam ser oferecidos no sentido de que o aluno tenha desempenho favorável mais acentuado, indicando melhor aproveitamento de 
recursos e formação mais adequada, além de favorecer o desenvolvimento de estratégias de ensino e aprendizagem.

\subsection{Delimitação temática do trabalho}

O fato de este trabalho lidar com um tema muito amplo reforça a necessidade de se delimitar com precisão a esfera de atuação da pesquisa, a fim de deixar claras as razões pelas quais cada tópico foi abordado no nível de profundidade e atualidade apresentado.

Nesse estudo, os focos centrais de investigação são os estilos de aprendizagem e o impacto que eles podem causar no desempenho acadêmico dos alunos, mais precisamente, no ensino de Contabilidade.

Para viabilizar a execução desse propósito, optou-se por utilizar como instrumento de pesquisa, o Índice de Estilos de Aprendizagem de Felder-Soloman e, como local de pesquisa, um curso de graduação em Contabilidade de uma universidade pública estadual, neste caso a FEA-RP/USP.

Como variável de mensuração do desempenho dos alunos foi utilizada a média final das notas obtidas por eles nas disciplinas, antes das reavaliações.

\subsection{Hipóteses}

O assunto abordado no trabalho é estilo de aprendizagem e ensino de Contabilidade. Devido à amplitude do mesmo, foi preciso fazer uma delimitação para conseguir tratá-lo de forma um pouco mais específica, resultando no tema da pesquisa.

Sendo assim, pode-se constatar que a pesquisa trabalha com as seguintes variáveis: 
- Dependente (y): desempenho acadêmico do aluno, que tem como indicador as médias finais das notas obtidas pelos alunos nas disciplinas do curso de graduação em Contabilidade da FEA-RP, antes das reavaliações;

- Independentes $(\mathbf{x})$ : estilos de aprendizagem dos alunos $\left(\mathrm{x}_{1}\right)$, professores $\left(\mathrm{x}_{2}\right)$ e disciplinas $\left(\mathrm{x}_{3}\right)$, cujos indicadores são os valores obtidos como resultado da aplicação do Índice de Estilos de Aprendizagem de Felder-Soloman para os alunos e professores, e para as disciplinas, questionário desenvolvido pelos pesquisadores com base no Modelo de Felder-Silverman (Apêndice B).

Considerando que os instrumentos utilizados para avaliação dos estilos de aprendizagem permitem o levantamento dos estilos dos alunos $\left(\mathrm{x}_{1}\right)$, dos professores $\left(\mathrm{x}_{2}\right)$ e das disciplinas $\left(\mathrm{x}_{3}\right)$, com a indicação dos prováveis pontos fortes e possíveis tendências ou hábitos que possam estar conduzindo a dificuldades na vida acadêmica e que o desempenho dos alunos (y) é representado pelas médias das notas obtidas nas avaliações, podem ser formuladas as seguintes hipóteses:

- H01: não existe diferença no desempenho acadêmico em relação aos estilos de aprendizagem dos alunos;

- H02: não existe diferença no desempenho acadêmico em relação aos estilos de aprendizagem dos professores;

- H03: não existe diferença no desempenho acadêmico em relação aos estilos das disciplinas.

Num segundo momento, ao trabalhar a dependência da variável desempenho acadêmico (y) com as variáveis estilos de aprendizagem dos alunos $\left(\mathrm{x}_{1}\right)$ e estilos de aprendizagem dos professores $\left(\mathrm{x}_{2}\right)$, por meio de seus indicadores, elabora-se a seguinte hipótese: 
- H04: não existe diferença no desempenho acadêmico em relação aos estilos de aprendizagem dos alunos e dos professores.

Outro propósito a ser alcançado com esse estudo é avaliar a associação e dependência entre o desempenho acadêmico dos alunos, seus estilos de aprendizagem e os estilos das disciplinas. Tal fim pode ser atingido com base na relação dos indicadores das variáveis: desempenho acadêmico (y), estilos dos alunos $\left(\mathrm{x}_{1}\right)$ e estilos das disciplinas $\left(\mathrm{x}_{3}\right)$, conforme demonstra a quinta hipótese:

- H05: não existe diferença no desempenho acadêmico em relação aos estilos de aprendizagem dos alunos e das disciplinas.

A sexta hipótese surge da necessidade de avaliar se o desempenho acadêmico dos alunos ( $\mathrm{y})$ pode ser afetado pelos estilos dos professores $\left(\mathrm{x}_{2}\right)$ e das disciplinas $\left(\mathrm{x}_{3}\right)$ ministradas por eles:

- H06: não existe diferença no desempenho acadêmico em relação aos estilos de aprendizagem dos professores e das disciplinas.

Finalmente é feito o relacionamento entre todas as variáveis, o que permite avaliar o impacto dos estilos de aprendizagem dos alunos $\left(\mathrm{x}_{1}\right)$, professores $\left(\mathrm{x}_{2}\right)$ e disciplinas $\left(\mathrm{x}_{3}\right)$ no desempenho acadêmico dos alunos (y) do curso de graduação em Contabilidade da FEA-RP:

- H07: não existe diferença no desempenho acadêmico em relação aos estilos de aprendizagem dos alunos, professores e disciplinas.

A partir do exposto, apresenta-se a arquitetura de hipóteses desse trabalho, conforme a figura 1: 


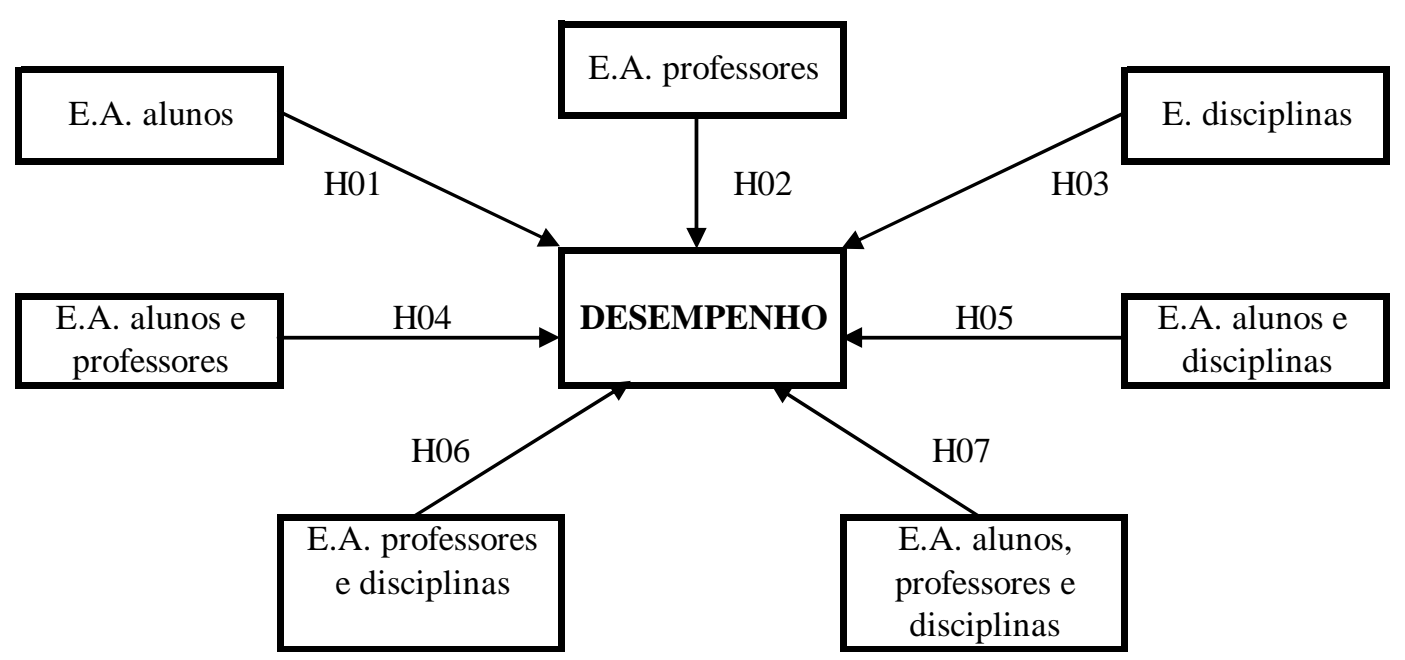

Figura 1 - Arquitetura de hipóteses.

Como se pode perceber, as hipóteses formuladas são possíveis respostas à questão da pesquisa e serão ou não confirmadas pelos resultados. Essa arquitetura de hipóteses nada mais é do que uma estrutura de referência que mostra as inter-relações entre as variáveis e as hipóteses. Facilita a obtenção de resultados e sua correspondente análise, ajudando a identificar quais resultados são importantes e justificados.

\subsection{Distribuição temática e estrutura do trabalho}

O trabalho foi estruturado em 5 Capítulos - incluindo este, introdutório. Os dois que se seguem apresentam a fundamentação teórica ligada ao tema da pesquisa e constituem o alicerce conceitual que sustenta todo o trabalho.

O Capítulo 2 ("Ensino, Aprendizagem e Estilos de Aprendizagem”) trata, primeiramente, do processo de ensino-aprendizagem e suas abordagens, sendo relacionadas as abordagens teóricas que mais influenciam os professores no Brasil. Em seguida, são discutidos os objetivos educacionais com base na taxonomia de Bloom, ou seja, quais são as mudanças desejadas ou que se espera que ocorram nos estudantes durante o processo educacional. 
Outro assunto explorado ainda no Capítulo 2 está relacionado às teorias da aprendizagem e suas classificações. A discussão sobre aprendizagem, apesar de não ser objetivo do estudo, foi necessária ao embasamento teórico do mesmo.

As definições de estilos cognitivos e estilos de aprendizagem também fazem parte deste capítulo, possibilitando a análise desses dois termos essenciais ao desenvolvimento do trabalho.

Na sequiência são descritos os modelos de avaliação dos estilos de aprendizagem de Kolb (1984) e Myers-Briggs (1970), que originaram instrumentos também aplicados a estudantes universitários e influenciaram o desenvolvimento do Modelo de Felder-Silverman (1988), o qual tem suas dimensões detalhadas por ser a base do instrumento aplicado neste estudo.

Por fim encontra-se a descrição do Índice de Estilos de Aprendizagem de FelderSoloman (1991), o que permite a compreensão de como o instrumento funciona na identificação dos estilos de aprendizagem, e uma breve análise a respeito de alguns trabalhos sobre estilos de aprendizagem e ensino de Contabilidade.

O Capítulo 3 ("Ensino de Contabilidade") tem como função principal caracterizar alguns aspectos do ensino de Contabilidade. Sua inclusão se justifica pela importância de se conhecer um pouco da evolução histórica da Disciplina e alguns elementos essenciais do ensino de Contabilidade, tais como: as competências e habilidades do ensino de Contabilidade, a qualidade do ensino de Contabilidade e os principais métodos e meios didáticos aplicados ao ensino de Contabilidade. Além disso, neste capítulo estão reunidas informações sobre a Faculdade de Economia, Administração e Contabilidade da Universidade de São Paulo (FEA/USP) e do campus de Ribeirão Preto (FEA-RP/USP), instituição onde foi realizada a pesquisa. 
O Capítulo 4 ("Metodologia”) apresenta os procedimentos metodológicos empregados na pesquisa de campo e os instrumentos de coleta de dados utilizados. Efetua uma caracterização das amostras, descreve a aplicação dos instrumentos e as ferramentas estatísticas usadas para análise dos resultados. Esse capítulo permite ao leitor saber como a pesquisa foi realizada e fornece informações capazes de possibilitar sua reaplicação.

Finalmente, o Capítulo 5 ("Resultados e Análise dos Resultados") expõe os resultados da pesquisa e tece considerações analíticas sobre os mesmos.

Nas "Considerações Finais" são apresentadas as conclusões correspondentes aos objetivos e hipóteses. São ressaltadas as contribuições do trabalho e sugestões para o desenvolvimento de novas pesquisas na área.

A figura 2 apresenta a estruturação temática dos capítulos que compõem esse trabalho. 

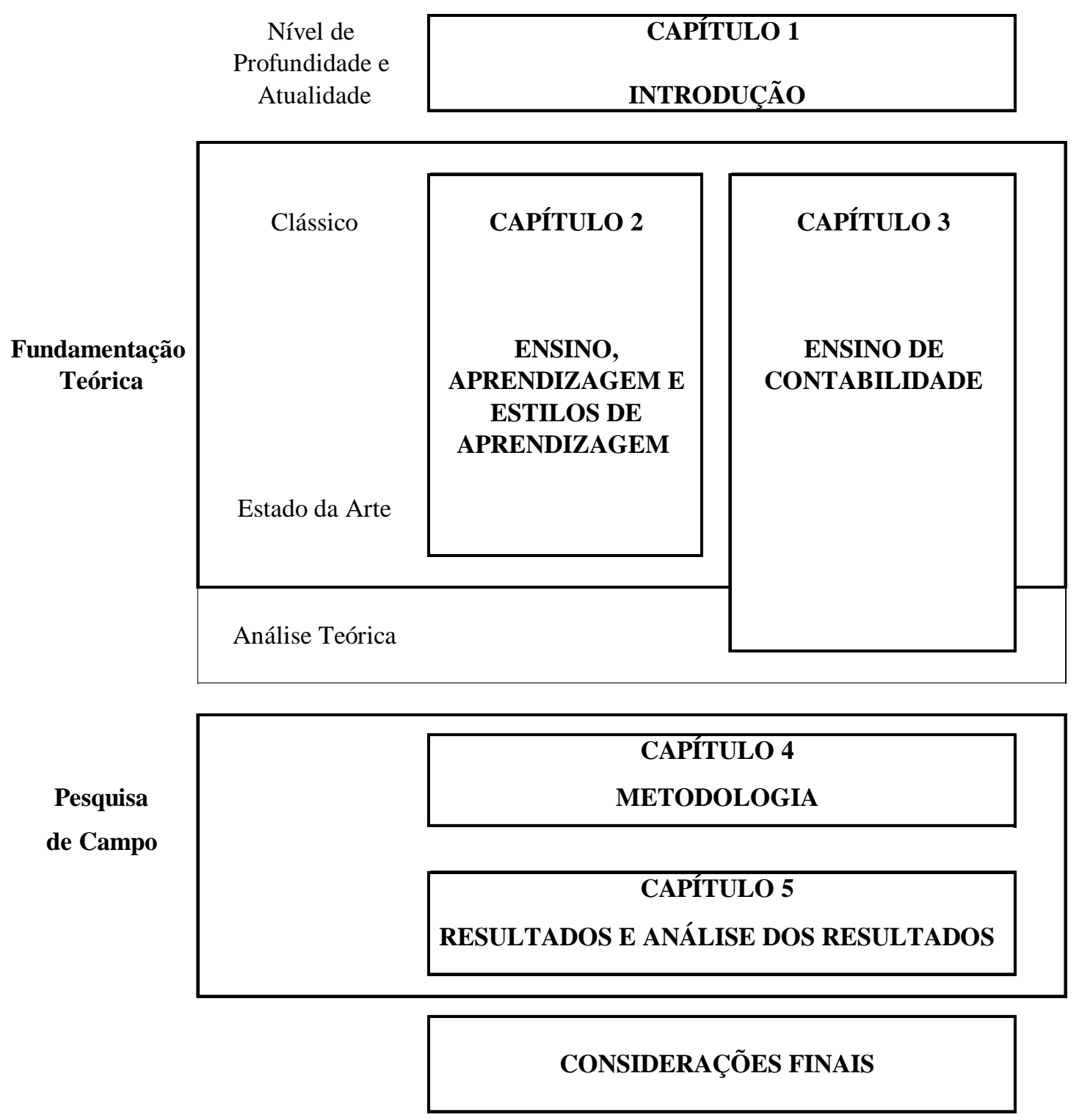

Figura 2 - Estruturação temática do trabalho 


\section{ENSINO, APRENDIZAGEM E ESTILOS DE APRENDIZAGEM}

De acordo com Tavares (2002, p. 80), a visão do ensino superior em Ciências Contábeis deve ser entendida pelos docentes e discentes, por meio da interação dos conceitos de educação, ensino, aprendizagem, e ainda, dos conceitos de formação e avaliação.

A educação é um processo social mediante o qual a sociedade integra seus novos membros, por meio da transmissão de valores, regras e padrões de comportamento. O que atualmente se entende por educação é resultado de um amplo encadeamento histórico de pesquisas que incluem diferentes áreas do conhecimento, tais como filosofia, sociologia e psicologia.

O ensino é entendido como uma atividade educacional mais específica voltada para apropriação de conhecimentos e saberes vinculados a uma escola, faculdade ou universidade.

Há uma tendência a confundir os dois conceitos - ensino e educação - e, como conseqüência, a mal empregá-los. Entretanto, eles se referem a diferentes dimensões e enfoques de uma mesma realidade.

A aprendizagem, por sua vez, é o processo cognitivo através do qual a pessoa adquire conhecimentos e se torna capaz de interagir com o mundo.

No ensino as atividades centralizam-se no professor, nas suas qualidades e habilidades. Já quando se fala em aprender, as atividades estão centradas no aprendiz (aluno), em suas capacidades, possibilidades, oportunidades e condições para que aprenda.

Formação é o processo de humanização dos indivíduos no qual se desenvolvem as capacidades críticas, criativas, motivadoras e as potencialidades do sujeito como pessoa, e, avaliação é uma dimensão do processo de ensino-aprendizagem que o coloca como objeto de análise. 
Nesse trabalho entende-se que ensino e aprendizagem possam estar indissociáveis, mas também que, dependendo da ênfase em um ou outro, as orientações das escolas poderão se diversificar. Como afirma Cornachione Júnior (2004, p. 96) "em função de fatores como tipo de instrução, de professores, de assunto, ou mesmo traços dos alunos, suas perspectivas e conhecimentos prévios, a combinação perfeita para a construção de um processo de ensinoaprendizagem pode ser diferente".

Para dar início à discussão sobre ensino e aprendizagem, primeiramente se faz necessário entender melhor como ocorre o processo de ensino-aprendizagem.

\subsection{O processo de ensino-aprendizagem}

O processo de ensino-aprendizagem existe pela interação entre os elementos fundamentais do ambiente educacional: instituição (suporte), professor (especialista), aluno (aprendiz) e assunto (currículo).

Representa a combinação especial de recursos e abordagens (ensino), de forma tal que a produção esperada (aprendizagem) possa ser alcançada com melhor consumo de recursos, conforme explica Cornachione Júnior (2004, p. 95) em seu estudo sobre tecnologia da educação e cursos de Ciências Contábeis. Sendo assim, esse estudo se concentra nas situações concretas de ensino e aprendizagem, através do agente formal, a escola, envolvendo as atividades dos professores e alunos frente aos conteúdos de ensino.

Observa-se, atualmente, que o sistema educacional ainda é muito dependente do professor, da sala de aula, das técnicas e dos recursos instrucionais e a aprendizagem, dessa forma, é decorrente das atividades de ensino. Com isso, torna-se importante conhecer e discutir alguns fatores relacionados ao ensino, tais como, os aspectos metodológicos e as correntes teóricas que sustentam o comportamento do professor. 
Os aspectos metodológicos do ensino envolvem: planejamento, definição dos objetivos, seleção e organização dos conteúdos, definição dos métodos e recursos instrucionais e avaliação da aprendizagem.

Dentro do planejamento do ensino estão todas as atividades a serem desenvolvidas pelo professor e seus alunos, bem como a definição dos recursos necessários para atingir os objetivos propostos e tornar a relação ensino-aprendizagem eficiente e eficaz (BELHOT, 1997: 17).

A primeira etapa na elaboração do planejamento do ensino é a determinação dos objetivos, ou seja, a especificação daquilo que se espera que o aluno aprenda e não o que o professor pretende ensinar.

Pode-se observar que na definição dos objetivos de cada disciplina do curso de graduação em Contabilidade da FEA-RP, analisadas neste trabalho, essa especificação não ficou muito clara, pois, são encontradas declarações dos dois tipos, tanto daquilo que o professor espera que o aluno aprenda como o que ele pretende ensinar (ver Apêndice A). Essa etapa é muito importante e, portanto, sugere-se que os objetivos sejam revistos.

Na sequiência é necessário estabelecer a matéria que será trabalhada com os alunos (conteúdo programático) e como os tópicos serão apresentados. Em seguida definem-se os métodos e recursos instrucionais que serão utilizados, isto é, as formas de organização das condições externas à aprendizagem e os veículos utilizados para disseminar o conhecimento.

A última etapa é a avaliação, que consiste em verificar se os objetivos foram atingidos e em que grau de satisfação.

Com relação às correntes teóricas que sustentam o comportamento do professor em situações de ensino e aprendizagem, principalmente em sala de aula, adotou-se os conceitos expostos por Mizukami (1986), com algumas adaptações para efeito comparativo. 
Como observa Mizukami (1986, p.1), para entender o fenômeno educativo, faz-se necessário refletir sobre os seus diferentes aspectos: "É um fenômeno humano, histórico e multidimensional. Nele estão presentes, tanto a dimensão humana quanto a técnica, a cognitiva, a emocional, a sócio-política e cultural". Conseqüentemente, entende-se o fenômeno educativo como um objeto em permanente construção e com diferentes causas e efeitos de acordo com a dimensão focalizada.

Esses aspectos são comparados segundo as diferentes opções pedagógicas, que, para Mizukami (1986, p.2-4), “poderiam estar fornecendo as diretrizes à ação docente, mesmo considerando-se que a elaboração que cada professor faz delas é individual e intransferível".

Levando-se em conta a complexidade do tema e a necessidade de maiores investigações empíricas e teóricas, serão expostas as abordagens do processo de ensinoaprendizagem que mais influenciam os professores no Brasil: abordagem tradicional, comportamentalista, humanista, cognitivista e sócio-cultural.

De acordo com Santos (2003, p. 82) as diversas abordagens teóricas que procuram explicar o processo de ensino-aprendizagem podem ser agrupadas e sistematizadas de diferentes formas, dependendo do enfoque do autor. Deve ficar claro que as diferentes classificações não têm limites totalmente definidos e que as abordagens teóricas não se constituem em referenciais completamente puros e fechados, sem pontos de interligação.

Parece, pelas diversas abordagens, que as teorias e seus diferentes enfoques ainda não constituem um corpo de conhecimentos capazes de explicar e ou predizer "todos" os aspectos do fenômeno educativo em suas diferentes situações. Por outro lado, é inegável que a educação não pode ser analisada isoladamente, sem considerar a sociedade-cultura envolvida, nem tampouco o seu momento histórico, com todos os seus efeitos sobre os indivíduos.

Também se pode inferir que a escola, com todas as suas críticas, ainda tem sido o local ideal para a realização do processo de ensino e aprendizagem e, para tanto, deveria utilizar-se 
de todos os meios materiais, humanos e tecnológicos possíveis para atingir os seus objetivos

(SANTOS, 2003: 82).

O quadro comparativo exposto a seguir (quadro 1) procura identificar, por meio de seus aspectos comuns, cada classificação, segundo as abordagens detalhadas por Mizukami.

\begin{tabular}{|c|c|c|c|c|}
\hline ABORDAGENS & \multicolumn{4}{|c|}{ ELEMENTOS RELEVANTES } \\
\hline & Escola & Aluno & Professor & \begin{tabular}{|c|} 
Ensino e \\
Aprendizagem \\
\end{tabular} \\
\hline TRADICIONAL & $\begin{array}{l}\text { É o lugar ideal para } \\
\text { a realização da } \\
\text { educação. }\end{array}$ & $\begin{array}{l}\text { É um ser } \\
\text { passivo. }\end{array}$ & $\begin{array}{l}\text { Transmissor do } \\
\text { conteúdo; } \\
\text { autoridade. }\end{array}$ & $\begin{array}{l}\text { Obedece a uma } \\
\text { seqüência lógica de } \\
\text { aulas expositivas } \\
\text { com exercícios de } \\
\text { fixação. } \\
\end{array}$ \\
\hline COMPORTAMENTALISTA & $\begin{array}{l}\text { Uma agência } \\
\text { educacional. }\end{array}$ & $\begin{array}{l}\text { Elemento para } \\
\text { quem o material } \\
\text { é preparado. }\end{array}$ & $\begin{array}{l}\text { Organizador e } \\
\text { aplicador dos } \\
\text { meios que } \\
\text { garantem a } \\
\text { eficiência e } \\
\text { eficácia do } \\
\text { ensino. }\end{array}$ & \begin{tabular}{|l} 
Ênfase nos meios \\
(recursos \\
audiovisuais, \\
instrução \\
programada, \\
tecnologias de \\
ensino, máquinas \\
de ensinar, \\
computadores etc.).
\end{tabular} \\
\hline HUMANISTA & \begin{tabular}{|l|} 
Oferece condições \\
ao desenvolvimento \\
e autonomia do \\
aluno de forma \\
democrática. \\
\end{tabular} & É um ser ativo. & $\begin{array}{l}\text { É o facilitador } \\
\text { do processo de } \\
\text { ensino- } \\
\text { aprendizagem. }\end{array}$ & \begin{tabular}{|l} 
Obedece ao \\
desenvolvimento \\
psicológico do \\
aluno.
\end{tabular} \\
\hline COGNITIVISTA & \begin{tabular}{|l|} 
Deve dar condições \\
para o aluno \\
aprender por si \\
próprio; reconhece \\
a prioridade \\
psicológica da \\
inteligência sobre a \\
aprendizagem. \\
\end{tabular} & $\begin{array}{l}\text { É } \\
\text { essencialmente } \\
\text { ativo. }\end{array}$ & $\begin{array}{l}\text { Criador de } \\
\text { situações } \\
\text { desafiadoras; } \\
\text { estabelece } \\
\text { condições de } \\
\text { reciprocidade e } \\
\text { cooperação } \\
\text { moral e racional. } \\
\end{array}$ & $\begin{array}{l}\text { Desenvolve a } \\
\text { inteligência do } \\
\text { sujeito numa } \\
\text { situação social; } \\
\text { facilitar o "aprender } \\
\text { a aprender". }\end{array}$ \\
\hline SÓCIO-CULTURAL & \begin{tabular}{|l|} 
Proporciona meios \\
para que a educação \\
se processe em seus \\
múltiplos aspectos.
\end{tabular} & \begin{tabular}{|l} 
Pessoa que \\
determina e é \\
determinada \\
pelo social; \\
capaz de operar \\
mudanças na \\
realidade.
\end{tabular} & $\begin{array}{l}\text { Direcionador e } \\
\text { condutor do } \\
\text { processo de } \\
\text { ensino- } \\
\text { aprendizagem } \\
\text { por meio da } \\
\text { relação } \\
\text { horizontal. } \\
\end{array}$ & $\begin{array}{l}\text { Objetivos definidos } \\
\text { a partir das } \\
\text { necessidades } \\
\text { concretas do } \\
\text { contexto histórico- } \\
\text { social dos sujeitos. }\end{array}$ \\
\hline
\end{tabular}

Quadro 1 - Abordagens do processo de ensino-aprendizagem

Fonte: Adaptado de SANTOS (2003, p. 82).

No próximo tópico detalham-se os aspectos dos objetivos educacionais com base na taxonomia de Bloom. Os relacionados à seleção e organização do conteúdo e aos métodos e recursos instrucionais serão detalhados mais adiante, focando-se especificamente no ensino de 
Contabilidade. A questão da avaliação da aprendizagem não será abordada tendo em vista ser este um assunto amplo e complexo e que foge um pouco aos objetivos desse estudo.

\subsection{Objetivos educacionais - Taxonomia de Bloom}

Uma das decisões estratégicas que o ensino exige é a que se refere à determinação dos objetivos educacionais. Estabelecer objetivos educacionais significa formular explicitamente as mudanças desejadas ou que se espera que ocorram nos estudantes quando do processo educacional, ou seja, quais mudanças são esperadas com relação às formas de pensar, sentir e agir. Isso significa especificar o que se espera que o aluno aprenda e não o que o professor pretende ensinar.

Três fatores devem ser considerados, seja para formulação dos objetivos para a educação, para uma escola ou para uma disciplina: o tempo, as condições disponíveis e o nível do grupo de estudantes envolvidos.

Para que os objetivos estabelecidos sejam alcançados é importante que eles tenham sido identificados claramente e que o trabalho esteja orientado por um plano. Bloom (1972) relaciona algumas reflexões que podem ajudar a estabelecer objetivos educacionais:

- Qual é o nível atual de desenvolvimento dos estudantes?

- Quais são suas necessidades?

- Quais são seus interesses?

- Quais informações vão estar disponíveis aos estudantes?

- Examinar as condições e problemas da vida contemporânea de modo a oferecer aos estudantes novas oportunidades;

- Que atividades são esperadas que os indivíduos venham a desempenhar?

- Quais os problemas que provavelmente encontrarão? 
- Que oportunidades poderão ter para trabalhar e auto realizar-se?

Desde 1948, um grupo de educadores assumiu a tarefa de classificar metas e objetivos educacionais. Eles propuseram-se a desenvolver um sistema de classificação (taxonomia) de objetivos para três domínios: o cognitivo, o afetivo e o psicomotor:

- Domínio Cognitivo: abrange os objetivos que enfatizam relembrar ou reproduzir algo que foi aprendido, ou que envolvem a resolução de alguma atividade intelectual para a qual o indivíduo tem que determinar o problema essencial, reorganizar o material ou combinar idéias, métodos ou procedimentos previamente aprendidos;

- Domínio Afetivo: envolve objetivos que enfatizam o sentimento, a emoção ou o grau de aceitação ou rejeição. Tais objetivos são expressos como interesses, atitudes ou valores;

- Domínio Psicomotor: compreende objetivos que enfatizam alguma habilidade muscular ou motora.

O presente estudo revela maior interesse pelo domínio cognitivo, e, sendo assim, este será abordado mais detalhadamente.

A taxonomia elaborada por Bloom et al. (1956) para a classificação de objetivos educacionais em seu domínio cognitivo compreende seis categorias principais: conhecimento, compreensão, aplicação, análise, síntese e avaliação:

1. Conhecimento - nesse nível espera-se que o aluno traga à sua mente, ou seja, recupere em sua memória, o material apropriado (conceito, método, processo etc.) para responder algo ou resolver um problema;

2. Compreensão - quando o objetivo é classificado no nível de compreensão espera-se que o aluno possa interpretar e/ou inferir algo a partir de conhecimentos já sedimentados sem a necessidade de recuperar o material apropriado na mente, o que passa a ser automático, ou seja, representar o conhecimento de diversas maneiras tais como: criar um esquema, diagrama, simbologia etc.; 
3. Aplicação - nesse nível o aluno é capaz de aplicar seu conhecimento compreendido em outras realidades, como por exemplo, a partir do conhecimento e da compreensão de algoritmo ele pode utilizá-lo para modelar diversas situações;

4. Análise - quando o objetivo é classificado no nível de análise espera-se que o aluno possa explicar, de uma maneira clara e organizada, como ele aplicou determinado conhecimento compreendido na resolução de problemas ou no encadeamento de idéias utilizadas nessa resolução;

5. Síntese - no nível da síntese o aluno deve conseguir, a partir de análises, constituir e representar padrões ou estruturas que antes não haviam sido evidenciadas, ou seja, deve, por exemplo, ser capaz de elaborar um planejamento (plano de trabalho);

6. Avaliação - quando o objetivo é classificado nesse nível espera-se que o aluno consiga avaliar, julgar ou comparar algo a partir de padrões ou critérios selecionados, constituídos a partir de sínteses.

A idéia central da taxonomia é a de que aquilo que os educadores querem que os alunos saibam (definido em declarações escritas como objetivos educacionais) pode ser arranjado numa hierarquia do nível mais simples para o mais complexo, como expressa a figura 3 .

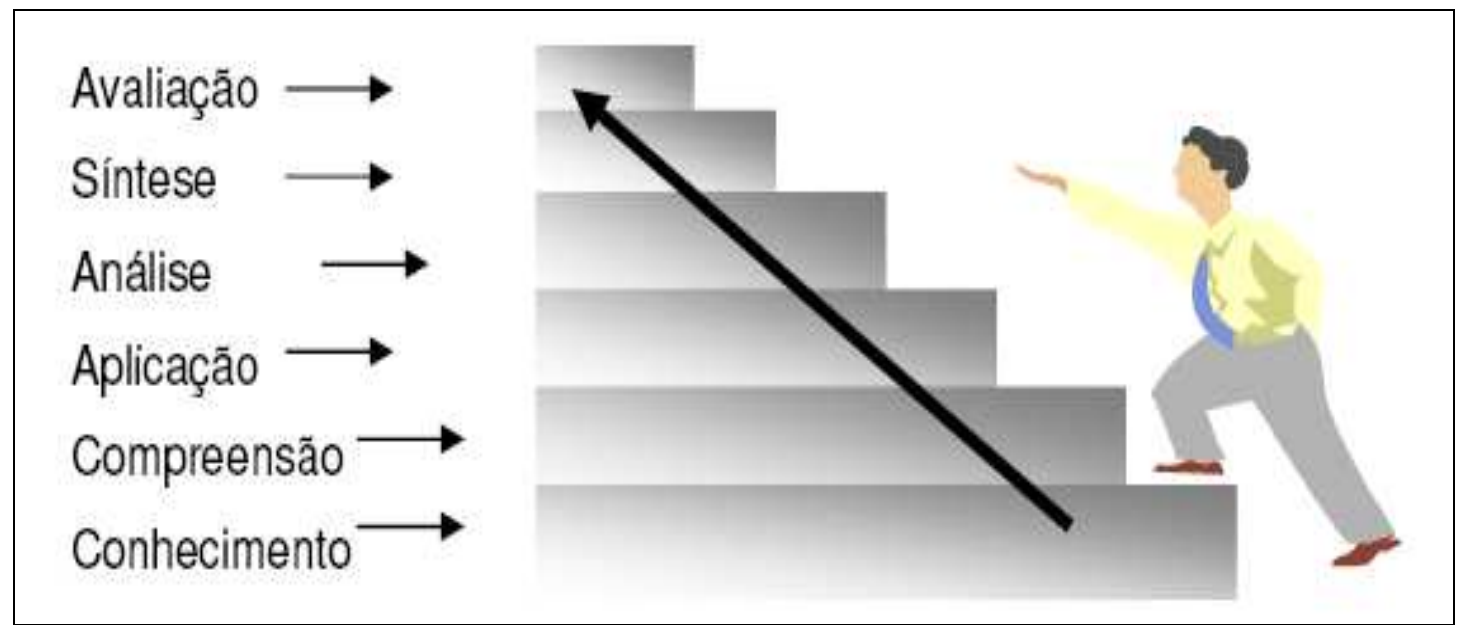

Figura 3 - Níveis da Taxonomia de Bloom

Fonte: Chaves e Arias (2003, p. 6). 
Os processos caracterizados pela taxonomia devem representar resultados de aprendizagem, ou seja, cada categoria taxonômica representa o que o indivíduo aprende não aquilo que ele já sabe, assimilado do seu contexto familiar ou cultural, e são cumulativos, uma categoria cognitiva depende da anterior e, por sua vez, dá suporte à seguinte.

As referidas categorias são organizadas num gradiente em termos de complexidade dos processos mentais, de modo que os objetivos classificados em uma categoria compreendam e se fundamentem em comportamentos incluídos nas categorias precedentes.

Na hierarquia não há certeza quanto à posição de síntese e avaliação. Ambas dependem da análise como um processo fundador, entretanto, síntese requer rearranjo das partes de um modo novo, original, enquanto que a avaliação requer a comparação com padrões, exigindo julgamento para determinar o bom, o melhor do que o melhor de todos.

De acordo com Belhot (1997, p. 21) "um aspecto comum aos autores é a preocupação com a verbalização dos objetivos, entendida como a afirmação por escrito." Ainda conforme Belhot, como o objetivo deve conter o que se espera que o aluno aprenda e não o que o professor vai ensinar (descrição dos tópicos do programa da disciplina), os verbos utilizados nessa descrição devem refletir uma ação e de preferência que seja mensurável.

A taxonomia é apresentada no quadro 2 com amostras de verbos e de declarações de desempenho para cada nível: 


\begin{tabular}{|c|c|c|c|}
\hline NÍVEL & DEFINIÇÃO & $\begin{array}{c}\text { AMOSTRA DE } \\
\text { VERBOS }\end{array}$ & $\begin{array}{l}\text { AMOSTRA DE } \\
\text { DESEMPENHOS }\end{array}$ \\
\hline CONHECIMENTO & $\begin{array}{l}\text { O aluno irá recordar } \\
\text { ou reconhecer } \\
\text { informações, idéias e } \\
\text { princípios na forma } \\
\text { (aproximada) em que } \\
\text { foram aprendidos. }\end{array}$ & $\begin{array}{l}\text { Escreva } \\
\text { Liste } \\
\text { Rotule } \\
\text { Nomeie } \\
\text { Diga } \\
\text { Defina }\end{array}$ & $\begin{array}{l}\text { O aluno irá definir os seis níveis } \\
\text { da taxonomia de Bloom no } \\
\text { domínio cognitivo. }\end{array}$ \\
\hline COMPREENSÃO & $\begin{array}{l}\text { O aluno traduz, } \\
\text { compreende ou } \\
\text { interpreta informação } \\
\text { com base em } \\
\text { conhecimento prévio. }\end{array}$ & $\begin{array}{l}\text { Explique } \\
\text { Resuma } \\
\text { Parafraseie } \\
\text { Descreva } \\
\text { Ilustre }\end{array}$ & $\begin{array}{c}\text { O aluno irá explicar a proposta } \\
\text { da taxonomia de Bloom para o } \\
\text { domínio cognitivo. }\end{array}$ \\
\hline APLICAÇÃO & $\begin{array}{l}\text { O aluno seleciona, } \\
\text { transfere e usa dados } \\
\text { e princípios para } \\
\text { completar um } \\
\text { problema ou tarefa } \\
\text { com um mínimo de } \\
\text { supervisão. }\end{array}$ & $\begin{array}{l}\text { Use } \\
\text { Compute } \\
\text { Resolva } \\
\text { Demonstre } \\
\text { Aplique } \\
\text { Construa }\end{array}$ & $\begin{array}{l}\text { O aluno irá escrever um objetivo } \\
\text { educacional para cada um dos } \\
\text { níveis da taxonomia de Bloom. }\end{array}$ \\
\hline ANÁLISE & $\begin{array}{l}\text { O aluno distingue, } \\
\text { classifica e relaciona } \\
\text { pressupostos, } \\
\text { hipóteses, evidências } \\
\text { ou estruturas de uma } \\
\text { declaração ou } \\
\text { questão. }\end{array}$ & $\begin{array}{l}\text { Analise } \\
\text { Categorize } \\
\text { Compare } \\
\text { Contraste } \\
\text { Separe }\end{array}$ & $\begin{array}{c}\text { O aluno irá comparar e } \\
\text { contrastar os domínios afetivo e } \\
\text { cognitivo. }\end{array}$ \\
\hline SÍNTESE & $\begin{array}{l}\text { O aluno cria, integra e } \\
\text { combina idéias num } \\
\text { produto, plano ou } \\
\text { proposta, novos para } \\
\text { ele. }\end{array}$ & $\begin{array}{c}\text { Crie } \\
\text { Planeje } \\
\text { Elabore hipótese(s) } \\
\text { Invente } \\
\text { Desenvolva }\end{array}$ & $\begin{array}{l}\text { O aluno irá elaborar um esquema } \\
\text { de classificação para escrever } \\
\text { objetivos educacionais que } \\
\text { integre os domínios cognitivo, } \\
\text { afetivo e psicomotor. }\end{array}$ \\
\hline AVALIAÇÃO & $\begin{array}{l}\text { O aluno aprecia, } \\
\text { avalia ou critica com } \\
\text { base em padrões e } \\
\text { critérios específicos. }\end{array}$ & $\begin{array}{l}\text { Julgue } \\
\text { Recomende } \\
\text { Critique } \\
\text { Justifique }\end{array}$ & $\begin{array}{c}\text { O aluno irá julgar a efetividade } \\
\text { de se escrever objetivos } \\
\text { educacionais usando a } \\
\text { taxonomia de Bloom. }\end{array}$ \\
\hline
\end{tabular}

Quadro 2 - Taxonomia de Bloom - domínio cognitivo

Fonte: http://www.webquest.futuro.usp.br/recursos/bloom.html . Acesso em 10/05/2006.

Distribuir os objetivos estabelecidos em uma sequiência de aprendizagem, verificar e criar as condições para atingi-los e estabelecer as inter-relações necessárias, são elementos essenciais que contribuem para o sucesso no alcance dos objetivos.

Embora não seja foco dessa pesquisa, a discussão sobre objetivos educacionais e a taxonomia de Bloom foi incluída para reforçar a importância de se conhecer os estilos de 
aprendizagem durante o processo educacional. Isso significa que qualquer proposta de mudança originada pelo conhecimento dos estilos de aprendizagem, deve passar, inicialmente, pela definição dos objetivos educacionais, e a taxonomia de Bloom pode ajudar o professor a estabelecer aonde quer chegar dentro do processo de ensino-aprendizagem.

Após essa etapa, o conhecimento dos estilos de aprendizagem seria capaz de favorecer cada um dos níveis da taxonomia de objetivos educacionais, ou seja, seria uma alternativa para fazer com que os objetivos estabelecidos pelos professores fossem alcançados pelos estudantes.

Em relação ao ensino de Contabilidade, de acordo com o trabalho de Bertolini (2005), foram identificados alguns estilos de aprendizagem que podem resultar em estratégias de ensino mais eficazes. A partir da informação sobre os modos preferenciais de aprendizagem de seus alunos, o professor tem a possibilidade de ensinar de diferentes maneiras um mesmo conteúdo de tal forma que consiga atingir mais eficientemente os objetivos pretendidos. Essa alternativa pode criar um ambiente de aprendizagem que maximize a satisfação dos alunos, proporcionando motivação e, consequentemente, um melhor desempenho.

\subsection{Teorias da aprendizagem}

Conforme expõe Cerqueira (2000, p. 9) há diversas formas de classificar as teorias de aprendizagem, sendo que uma delas é baseada na distinção filosófica entre o modelo empirista e o modelo racionalista. Outra forma é distinguir as teorias da aprendizagem entre teorias estímulo-resposta (S-R) ou comportamentais e teorias cognitivas.

A teoria empirista recorre ao método de associação de idéias ou de eventos para explicar como se processa a aprendizagem e realça a importância das experiências sensoriais. É descendente da tradição filosófica do associacionismo de Hobbes, Locke, Hume e outros. 
A perspectiva do associacionismo considera a aprendizagem como o resultado de um processo experiencial e mental de associações de idéias, propondo um modelo de aprendizagem para aquisição de conhecimentos que parta de uma apresentação inicial de conteúdos simples para os mais complexos, o que possibilita que sejam paulatinamente apreendidos ou assimilados. Assim, a aprendizagem se processa numa progressividade associativa. Os principais teóricos e pesquisadores da aprendizagem durante a primeira metade do século XX - Thorndike, Pavlov, Hull, Skinner entre outros - adotaram a perspectiva do associacionismo.

A teoria racionalista propõe a razão humana como a fonte essencial de aquisição de conhecimento. Valoriza os problemas de organização, compreensão, interpretação e significado do que é aprendido e a influência dos fatores inatos nesse processo. Teve como precursores os filósofos Descartes, Leibniz e Kant.

Para os comportamentalistas (ou behavioristas) a ciência tem como função descobrir a ordem natural dos eventos, mostrando que certos acontecimentos se relacionam sucessivamente com os outros.

De acordo com Mizukami (1986), no Brasil um dos mais difundidos e estudados representantes da análise funcional do comportamento no contexto educacional é Skinner.

A teoria e a técnica fundamentadas no Condicionamento Operante de Skinner, na associação entre uma resposta desejada e um estímulo reforçador dessa resposta que a segue, são algumas das mais influentes concepções da psicologia nas questões associadas à aprendizagem. Skinner pertence ao mesmo grupo de teorias estímulo-resposta (S-R) nas quais o reforço desempenha um papel fundamental, como nos casos das teorias anteriores de Thorndike e Hull.

Segundo Cerqueira (2000, p. 12) para Skinner grande parte do comportamento humano é considerado comportamento operante e a aprendizagem é a aquisição de um novo 
comportamento condicionado a um processo em que o estímulo reforçador, chamado reforço positivo, tem o papel predominante, assim como o reforço negativo seria aplicado para fortalecer a resposta desejada na eliminação de um comportamento indesejado. O reforço positivo oferece alguma coisa ao organismo e o negativo permite a retirada de algo indesejável.

Ainda conforme essa mesma autora, a área mais atuante de aplicação das técnicas e idéias de Skinner tem sido a área educacional, nos métodos de ensino programado, controle e organização das situações de aprendizagem, elaboração de tecnologias de ensino, treinamento e reciclagem em empresas, trabalho com excepcionais entre outros.

Cerqueira (2000, p. 12-13) também relaciona algumas conseqüências dessa teoria para o emprego pelos professores em sua prática que são as que seguem:

1. Os processos de aprendizagem sem reforços não conduzem à mudança de comportamento desejada;

2. O reforço deve ser aplicado imediatamente após o bom resultado;

3. Se o objetivo é fazer desaparecer um tipo de comportamento indesejado em um aluno, não se deve dar nenhum reforço;

4. Os reforços em si mesmos não implicam forçosamente em efeito positivo de aprendizagem.

Nesse sentido, para que se possa aplicar a análise comportamental no ensino é necessário considerar que, tanto os elementos do ensino como as respostas do aluno, podem ser analisados em seus componentes comportamentais.

Lopes (2002, p. 16) afirma que ensinar, nessa abordagem, requer um arranjo de contingências, e esse arranjo depende de elementos observáveis onde o comportamento ocorre: um evento antecedente, uma resposta, um evento conseqüente (reforço) e fatores contextuais. Não se pode deixar de frisar que esse arranjo e planejamento de contingências de 
reforço que levaram o aluno a aprender são de responsabilidade do professor. Ele deverá garantir a aquisição do comportamento.

A autora ressalta que a eficiência na elaboração e utilização dos modelos depende igualmente de habilidades do professor. Este tem um papel importante já que auxilia o aluno, no entanto, ele precisa estar bem atento para o tipo de auxílio que fornece, pois embora a responsabilidade do processo recaia sobre o professor, o importante é que o processo ensinoaprendizagem, promova no aluno a incorporação do controle das contingências de reforço, fazendo emergir comportamentos de auto-governo.

Já as teorias cognitivistas, conforme Belhot (1997, p. 10) passaram a ter maior importância a partir de uma concepção de aprendizagem humana mais voltada para os processos de codificar, armazenar e recuperar informações, aberta a indagações estratégicas, tomada de decisão e solução de problemas. É uma concepção de aprendizagem onde o ser humano é um organismo que age sobre o ambiente e o monitora continuamente em busca de informação e não mais um organismo passivo que reage.

A aprendizagem passou a ser encarada como um processo de modificação e combinação de estruturas cognitivas, e a informação tornou-se a matéria-prima da aprendizagem.

Os psicólogos conhecidos como gestaltistas - Wertheimer, Koffka e Köhler - fazem parte de uma das tendências teóricas mais coerentes e coesas da história da Psicologia: a Gestalt.

Os gestaltistas, tanto quanto os behavioristas se consideram estudiosos do comportamento humano. No entanto, não concordam com os últimos no que diz respeito à importância exclusiva da relação entre o estímulo e a resposta no aprendizado, dizendo que o comportamento deve ser estudado no seu aspecto mais global, levando em conta as condições que alteram ou determinam a percepção do objeto ou do estímulo. 
De acordo com os princípios da Gestalt, o professor deveria esforçar-se em promover um aprendizado em que: (CERQUEIRA, 2000: 14):

1. Fortaleça o raciocínio;

2. Elabore perguntas para que o aluno raciocine;

3. Enfatize os princípios estruturais sem centrar os comentários apenas nos detalhes;

4. Localize os detalhes em um contexto cognitivo;

5. Apresente cada disciplina de tal forma que apareça claro o conceito em um contexto mais amplo. Os grandes contextos e as conexões lógicas entre os setores relacionados parcialmente devem ser claramente detectáveis;

6. Conduza o ensino com segurança ao êxito desejado quando os novos modelos de comportamento são construídos e praticados por meio do ensino ativo;

7. Repita diversas vezes os novos modelos de comportamento em situações aparentemente distintas.

Ao terminar esse tópico onde se procurou explicitar os principais aspectos das teorias apresentadas e as implicações diretas de cada uma delas na aprendizagem, uma questão remete a um problema crucial na área da educação: a relação entre propostas teóricas e prática pedagógica.

Antes de escolher entre uma ou outra abordagem, ou buscar agrupá-las como se fossem equivalentes, o aprofundamento teórico em cada uma dessas concepções, certamente ocasionará maiores reflexões.

Como essa pesquisa tem por objetivo avaliar o impacto dos estilos de aprendizagem sobre o desempenho acadêmico dos alunos, a discussão sobre aprendizagem foi necessária, visto que é um conceito relacionado a desempenho, porém com diferença significativa: aprendizagem pode ser entendida como uma mudança de comportamento e desempenho como 
a realização de uma atividade ou grupo de atividades dentro de expectativas previamente estabelecidas.

Para os fins desse trabalho, o conceito de aprendizagem está inserido em um contexto bem particular: o do aluno adulto (curso superior) em ambiente corporativo (negócios, Contabilidade). De acordo com Cornachione Júnior (2004, p. 55) a ausência de conquistas ou desempenhos, em determinado ambiente educacional, pode ter tantas razões distintas que torna a análise complexa, porém, com fundamentação teórica apropriada, ou em outras palavras, com respostas certas para os problemas vigentes, tal tarefa pode ser extremamente racionalizada.

Em resumo, essa discussão apresentou a fundamentação teórica sobre aprendizagem, exibindo teorias distintas e suas características. Não cabe aqui uma escolha particular de qual abordagem vai ajudar a solucionar a questão dessa pesquisa. O que os pesquisadores e suas teorias dizem é para analisar, propor e praticar a alternativa mais apropriada para cada combinação de elementos: assunto, aluno, contexto, instituição, ambiente social etc.

No intuito de manter o foco do trabalho, na seqüência serão abordados os estilos cognitivos e os estilos de aprendizagem.

\subsection{Estilos cognitivos e estilos de aprendizagem}

Os estudos sobre estilos cognitivos e estilos de aprendizagem foram desenvolvidos a partir de interesses nas diferenças individuais e derivam de diversos referenciais teóricos, gerando dificuldades de definição e operacionalização dos conceitos. Desse modo, para uma análise sobre o assunto é imprescindível enfocar tanto as abordagens que dizem respeito ao que se denomina estilo cognitivo quanto àquelas que se referem mais especificamente aos estilos de aprendizagem. 
Conforme Cerqueira (2000, p. 31) esses dois termos têm sido utilizados pelos pesquisadores e teóricos sem uma diferenciação clara entre seus conceitos: "Enquanto alguns acreditam que os dois conceitos podem ter o mesmo significado e possam ser usados indistintamente, outros os consideram diferentemente e se dedicam a defini-los distintamente".

Devido a essa situação, apesar de o foco deste trabalho ser estilos de aprendizagem, inicialmente será feita uma breve referência aos estilos cognitivos.

\subsubsection{Estilos cognitivos}

Dentre as várias características individuais apontadas como mediadoras no processo de ensino-aprendizagem, os estilos cognitivos têm sido objeto de estudo de pesquisadores de diversos países (BARIANI, SISTO E SANTOS, 2000).

Conforme Lopes (2002, p. 32) os estilos cognitivos não têm relação com a eficácia e a eficiência; podem ou não ser considerados mais ou menos adequados a determinadas situações, diferenciando-se das habilidades cognitivas que podem levar a diferentes níveis de desempenho. Não se trata de uma habilidade, mas se referem ao modo preferencial de alguém usar habilidades, ou uma preferência individual no processamento da informação. Descrevem, portanto, o modo típico de uma pessoa pensar, recordar ou resolver um problema. Os estilos cognitivos são usualmente considerados como uma dimensão bipolar, enquanto as habilidades cognitivas são unipolares (indo de zero para um valor máximo).

Ainda de acordo com Lopes (2002, p. 33):

Ter uma habilidade em quantidade elevada é freqüentemente considerado útil, mas ter um estilo cognitivo particular simplesmente revela uma tendência para comportar-se de certa maneira. Dessa forma, não cabe a pergunta: "Qual é o melhor tipo de estilo?" A pergunta correta parece ser: "Qual estilo é mais adequado para determinada proposta?” [...] mas identificar o estilo não é suficiente e a pergunta necessária passa a ser: "Como podemos usar o que nós conhecemos a respeito dos estudantes para ajudá-los a aprender melhor?”. 
Segundo Messick (1984; 1994) apud Lopes (2002, p. 33) “os estilos cognitivos se desenvolvem de modo compatível com as tendências subjacentes à personalidade". O autor também afirma que os estilos cognitivos, além de influenciarem o processo de aprendizagem e a organização do conhecimento, colocam em evidência suas implicações na própria natureza do comportamento social e das interações humanas nos diferentes grupos sociais.

Para esse pesquisador uma melhor compreensão dos estilos proporciona implicações educacionais, principalmente no que tange a melhoria dos métodos instrucionais, aprimoramento das ações e concepções do professor, intensificação da aprendizagem e estratégias de pensamento do aluno, ampliação na orientação e tomada de decisão vocacional, alargamento na forma de conceber as metas e resultados educacionais e aprimoramento das demandas relativas aos estilos dos meios educacionais.

Conforme Bariani, Sisto e Santos (2000) o estudo dos estilos cognitivos tem como desafio o desenvolvimento de instrumentos válidos, capazes de medir conjuntos de diferentes dimensões de estilos cognitivos e que sejam apropriados para a avaliação de grandes grupos de pessoas, em situações educacionais. De acordo com esses autores, na literatura existe um grande número de dimensões de estilos cognitivos descritas, porém quatro dimensões são mais investigadas: dependência / independência de campo; reflexibilidade / impulsividade; pensamento convergente / divergente; holista / serial.

Lopes (2002, p. 35-36) relaciona as principais características dessas dimensões conforme pode ser observado a seguir:

- Dependente / Independente de campo. O estilo dependente de campo é sintético, intuitivo, integrador e conta com uma estrutura externa de referência. As pessoas com esse estilo são hábeis em situações que demandam percepção pessoal e habilidade interpessoal. O estilo independente de campo é analítico, crítico, autônomo, conta com uma estrutura interna de referência e é distante nas relações sociais; 
- Reflexibilidade / Impulsividade. Essa dimensão refere-se ao modo como as pessoas reagem frente às situações-problemas nas quais existem distintas hipóteses de solução e que devem ser contrastadas adequadamente. O estilo impulsivo atua antes de escolher, é encontrado em pessoas que apresentam um pensamento menos organizado, enquanto o estilo reflexivo diz respeito àquelas pessoas que refletem antes de empreender um determinado curso de ação e possuem pensamentos mais organizados;

- Convergente / Divergente. O pensamento convergente está associado ao pensamento lógico, identificado de perto com o fator raciocínio. As pessoas que apresentam esse estilo são hábeis em resolver problemas formais e tarefas mais estruturadas, embora sejam mais inibidas emocionalmente e adotem posturas mais conservadoras. A divergência de pensamento é identificada com a criatividade (processos cognitivos superiores). As pessoas com pensamento divergente mostram-se mais criativas e originais e se sentem mais à vontade para resolver problemas menos estruturados. Socialmente são mais irritadiças, destrutivas e ameaçadoras;

- Holista / Serial. O estilo holista tende a dar uma ênfase maior ao contexto global. Os holistas podem resolver rapidamente problemas complexos ou unir as coisas e são, muitas vezes, bons sintetizadores. Já os serialistas dão maior ênfase aos tópicos separados e às seqüências lógicas. São, muitas vezes, bons analistas e hábeis para resolverem problemas.

A teoria de dependência versus independência de campo de Witkin e Goodenough (1977) se destaca pelo maior número de investigações e aplicações no contexto de ensinoaprendizagem. Inicialmente, foi descrito como estilo perceptivo, relacionado à forma como as pessoas coordenam informações provenientes de diferentes canais sensoriais, em particular a visão e o sentido sinestésico. Posteriormente foi pesquisado e conceituado como estilo propriamente cognitivo, relacionado ao conjunto de operações de conhecimento, de 
processamento de informações e não só meramente perceptivo (FIERRO in COLL, PALACIOS E MARCHESI, 1996).

Como dito inicialmente, embora não seja objeto de pesquisa, essa breve discussão sobre estilos cognitivos é importante para o embasamento teórico dos estilos de aprendizagem e, por esse motivo, foi realizada até esse ponto.

\subsubsection{Estilos de aprendizagem}

Riding e Cheema (1991) apud Cerqueira (2000, p. 38) afirmam que o conceito de estilos de aprendizagem emergiu nos anos 70 derivado diretamente dos estudos sobre os estilos cognitivos, estando os seus criadores mais interessados numa orientação para a ação, ou seja, aplicações mais práticas, nas áreas educacionais e de treinamento.

O termo estilo cognitivo, por outro lado, seria reservado para descrições teóricas, acadêmicas, traduzindo uma distinção entre os conceitos. No entanto, se os trabalhos sobre estilos de aprendizagem voltados para aplicações práticas fundamentam-se nas teorias sobre estilos cognitivos, esses últimos também teriam implicações práticas.

Os estilos de aprendizagem estão relacionados à forma particular de adquirir conhecimentos, habilidades ou atitudes através da experiência ou anos de estudo e seriam como um subconjunto dos estilos cognitivos. As teorias de estilos de aprendizagem os consideram como resultado da hereditariedade (código genético), educação, personalidade e da adaptação do indivíduo às demandas do ambiente.

Para a definição do que são estilos de aprendizagem encontra-se uma enorme variedade de respostas, dependendo das orientações teóricas adotadas. Cerqueira (2000, p. 3539), apresenta em seu estudo sobre estilos de aprendizagem em universitários, algumas das 
definições que considera mais significativas. $\mathrm{O}$ quadro 3 a seguir reúne essas definições e seus

autores.

\begin{tabular}{|c|c|}
\hline AUTORES & DEFINIÇÕES \\
\hline $\begin{array}{l}\text { Claxton e } \\
\text { Ralston (1978) }\end{array}$ & $\begin{array}{l}\text { Estilo de aprendizagem é uma forma consistente de responder e utilizar os estímulos em } \\
\text { um contexto de aprendizagem. }\end{array}$ \\
\hline $\begin{array}{l}\text { Dunn, Dunn \& } \\
\text { Price (1979) }\end{array}$ & $\begin{array}{l}\text { Estilo de aprendizagem é a maneira pela qual os indivíduos respondem a estímulos } \\
\text { ambientais, emocionais, sociológicos e físicos. }\end{array}$ \\
\hline Dunn (1986) & $\begin{array}{l}\text { Estilos de aprendizagem são as condições através das quais os indivíduos começam a } \\
\text { concentrar-se, absorver, processar e reter informações e habilidades novas e difíceis. }\end{array}$ \\
\hline Hunt (1979) & $\begin{array}{l}\text { A definição de estilo de aprendizagem baseia-se nas condições educativas com as quais o } \\
\text { aluno está em melhor situação para aprender, ou que estrutura necessita o aluno para } \\
\text { aprender melhor. }\end{array}$ \\
\hline Gregorc (1979) & $\begin{array}{l}\mathrm{O} \text { estilo de aprendizagem consiste em comportamentos distintos que servem como } \\
\text { indicadores da maneira como uma pessoa aprende e se adapta ao seu ambiente. }\end{array}$ \\
\hline Schmeck (1982) & $\begin{array}{l}\text { Estilo de aprendizagem é o estilo que um indivíduo manifesta quando se confronta com } \\
\text { uma tarefa de aprendizagem específica. É, também, uma predisposição do aluno em } \\
\text { adotar uma estratégia particular de aprendizagem, independentemente das exigências das } \\
\text { tarefas. }\end{array}$ \\
\hline Keefe (1982) & $\begin{array}{l}\text { Os estilos de aprendizagem são constituídos por traços cognitivos, afetivos e fisiológicos, } \\
\text { que funcionam como indicadores relativamente estáveis da forma como os alunos } \\
\text { percebem, interagem e respondem ao ambiente de aprendizagem. }\end{array}$ \\
\hline Butler (1982) & $\begin{array}{l}\text { Concebe estilos de aprendizagem como o significado natural da forma como uma pessoa, } \\
\text { efetiva e eficientemente, compreende a si mesma, o mundo e a relação entre ambos. } \\
\text { Indica uma maneira distinta do aluno se aproximar de um projeto ou episódio de } \\
\text { aprendizagem, independentemente da inclusão de uma decisão explícita ou implícita por } \\
\text { parte deste. }\end{array}$ \\
\hline Entwistle (1988) & $\begin{array}{l}\text { Estilo de aprendizagem é como uma orientação do indivíduo para a aprendizagem, ou } \\
\text { seja, a consistência na abordagem que um indivíduo demonstra na realização de tarefas } \\
\text { específicas de aprendizagem. }\end{array}$ \\
\hline Smith (1988) & $\begin{array}{l}\text { Os estilos de aprendizagem são como os modelos característicos pelos quais um } \\
\text { indivíduo processa a informação, sente e se comporta nas situações de aprendizagem. }\end{array}$ \\
\hline
\end{tabular}

Quadro 3 - Definições de estilos de aprendizagem e seus autores

Fonte: Elaborado pela autora com base em Cerqueira (2000, p. 35-39).

Pode-se observar que em todas essas definições os autores relacionam estilos de aprendizagem a modos (comportamentos) característicos de aprendizado, ou seja, à forma como as pessoas interagem com as condições, ambientes ou estruturas sob as quais se processa a aprendizagem. 
É possível notar, também, que alguns autores ressaltam a presença de fatores fisiológicos, emocionais e afetivos na conceituação de estilos de aprendizagem, enquanto outros os relacionam com estratégias ou posturas adotadas pelos indivíduos nas situações de aprendizagem.

Ainda dentre essas definições, é necessário destacar o trabalho de Dunn (1986), que corrobora com os propósitos desse estudo no ponto em que a autora afirma que quando os professores conhecem e respeitam os estilos de aprendizagem peculiares de seus alunos, proporcionando instrução em consonância com os mesmos, verifica-se um aumento de aproveitamento acadêmico e um decréscimo de problemas de ordem disciplinar, bem como melhores atitudes em relação à escola.

Kuri (2004, p. 79-80), que estudou os tipos de personalidade e estilos de aprendizagem, trazendo proposições para o ensino de Engenharia, também expõe algumas definições de estilos de aprendizagem. Dentre elas, estão os trabalhos de Kolb (1984), Felder e Silverman (1988), DeBello (1990) e Campbell, Campbell \& Dickinson (2000), como é expresso em seguida.

Kolb (1984) sugeriu que como resultado da bagagem hereditária, das experiências de cada um e das exigências do meio ambiente, as pessoas desenvolvem estilos de aprendizagem que enfatizam algumas habilidades sobre outras. Mediante as experiências de socialização na família, escola e trabalho, as pessoas resolvem os conflitos entre ser ativo e reflexivo e entre ser imediato e analítico de formas individualmente características, ou seja, cada pessoa desenvolve um estilo pessoal de aprendizagem.

Felder e Silverman (1988) entendem a aprendizagem como um processo de duas fases envolvendo a recepção e o processamento da informação. Na fase da recepção, a informação externa (captada pelos sentidos) e a informação interna (que surge introspectivamente) ficam disponíveis para o indivíduo, que seleciona o material a ser processado e ignora o restante. $\mathrm{O}$ 
processamento pode envolver simples memorização ou raciocínio indutivo ou dedutivo, reflexão ou ação, introspecção ou interação com outros indivíduos. O resultado é que o material é aprendido de uma forma ou de outra, ou então, não é aprendido. Desse modo, concluem que os estilos de aprendizagem referem-se aos modos pelos quais os indivíduos preferem receber e processar as informações.

Para DeBello (1990) estilo de aprendizagem é a maneira pela qual a pessoa absorve, processa e retêm a informação. Campbell, Campbell \& Dickinson (2000) afirmam que os estilos de aprendizagem referem-se às diferenças individuais na maneira como a informação é compreendida, processada e comunicada. Salientam que os educadores que respeitam as diferenças individuais entre os alunos, ao mesmo tempo em que apreciam e celebram a diversidade nas maneiras de aprender, ensinarão mais por meio de seus comportamentos do que por meio das estratégias.

De acordo com o que foi apresentado, pode-se concluir que existem vários conceitos de estilos de aprendizagem que se encontram apoiados em diferentes linhas de investigação e que, após 1976, o número de teorias de estilos de aprendizagem tem aumentado.

Apesar da diversidade, as teorias estão longe de serem excludentes, representando, ao contrário, um processo contínuo de formas diferentes de conceber um fenômeno tão complexo que é a aprendizagem.

Curry (1990) apud Cerqueira (2000, p. 38) destacou três problemas gerais na operacionalização das teorias sobre estilos de aprendizagem: uma confusão nas definições, uma fraqueza na confiabilidade e validade das medidas, bem como problemas relativos à identificação de características relevantes aos aprendizes e ao cenário educacional. Essa autora complementa que, diante desse panorama amplo de definições, pode-se corroborar a afirmação de Curry, segundo a qual um dos obstáculos mais importantes para o progresso e a 
aplicação da teoria dos estilos de aprendizagem na prática educacional é o vasto panorama de comportamentos que os vários modelos de estilos pretendem predizer.

Basicamente, todas essas concepções consideram a maneira particularmente estável com que o aprendiz organiza e controla as estratégias de aprendizagem na construção do conhecimento como sendo o foco dos estilos de aprendizagem. Portanto, a idéia de que os indivíduos têm diferentes maneiras de perceber e de processar a informação, irá implicar diretamente em diferenças nos processos de aprendizagem. Não significa, porém, que existem estilos bons ou maus, apenas diferentes estilos de aprendizagem.

Após a apresentação e reflexão sobre algumas teorias dos estilos de aprendizagem, é importante expor e analisar os modelos que servem para a avaliação desses estilos.

\subsection{Modelos de avaliação dos estilos de aprendizagem}

Devido à existência de diversos estilos de aprendizagem e suas várias classificações e abordagens, pesquisadores de áreas como educação e psicologia, começaram a acumular tais entendimentos em categorias ou inventários, a fim de organizar o desenvolvimento dessa linha de pesquisa. Surgiram, assim, os inventários dos estilos de aprendizagem ou learning styles inventories (LSI), instrumentos para avaliação desses estilos.

Os inventários de estilos de aprendizagem são, normalmente, baseados em dimensões bipolares para representar as diferentes formas de perceber e processar as informações e o modo de tomar decisões e organizar a própria vida, podendo fornecer boas estruturas para o planejamento do ensino.

Neste trabalho são destacadas as teorias que fundamentam alguns instrumentos disponíveis na literatura, utilizados na avaliação dos estilos de aprendizagem de estudantes universitários, que são as propostas de Kolb - LSI (1984, 1985, 1993), Myers-Briggs - MBTI 
(1970) e Felder-Silverman - ILS (1988, 1993). Kolb e Myers-Briggs serão tratados brevemente por terem influenciado o Modelo de Felder-Silverman, o qual será abordado mais detalhadamente, por referir-se ao modelo cuja teoria fundamenta o instrumento aplicado neste estudo.

\subsubsection{Experiential Learning - Modelo de Kolb}

Para Kolb (1984), o processo de aprendizagem é cíclico, passando por quatro fases: 1) experiência concreta (envolvimento); 2) observação reflexiva (pensar sobre a experiência; ouvir, observar); 3) conceituação abstrata (generalização ou princípios; criação de idéias, teorias) e 4) experimentação ativa (testar o que foi aprendido; tomada de decisões). ${ }^{1}$ Uma aprendizagem bem sucedida irá demandar do aluno de forma flexível a combinação dessas etapas que poderão evoluir para padrões estáveis e duradouros (estilos) que caracterizam a individualidade do aluno.

Nesse ciclo de aprendizagem que idealizou, Kolb identificou duas dimensões de aprendizagem distintas: percepção e processamento. Na primeira, constata-se que algumas pessoas percebem melhor a informação através de experiências concretas (como por exemplo, tocar, ver, ouvir), enquanto outras percebem melhor a informação abstratamente, por meio de conceitos mentais ou visuais, constituindo a oposição: Experiência Concreta versus Conceituação Abstrata (EC - CA). Na segunda, encontram-se pessoas que processam melhor a informação fazendo alguma experimentação com ela e outras que processam melhor pela observação reflexiva (pensando sobre as coisas), constituindo a oposição: Experimentação Ativa versus Observação Reflexiva (EA - OR).

\footnotetext{
${ }^{1}$ Mais informações disponíveis em http://reviewing.co.uk/research/experiential.learning.htm . Acesso em 05/05/2006.
} 
Essas duas dimensões podem ser combinadas para identificar as 4 categorias de estilos de aprendizagem de acordo com o Modelo de Kolb, como segue:

- Tipo 1 - Divergente (EC - OR) - Aprendizes divergentes respondem a explicações, mostrando a relação do conteúdo do curso com suas experiências, seus interesses e com a sua carreira futura. $\mathrm{O}$ termo divergente caracteriza bem esse estilo, pois se mostram habilidosos em situações que demandam idéias novas e criativas e que exigem capacidade de compreensão das pessoas. Preferem aprender pela experiência concreta e observação reflexiva. São capazes de analisar as situações sob diferentes pontos de vistas e relacionálos num todo organizado. Para ser efetivo com esse tipo de estudante, o professor deve funcionar como motivador;

- Tipo 2 - Assimilador (OR - CA) - Aprendizes assimiladores respondem a informação, apresentando uma organização de forma lógica e beneficiam-se, caso tenham tempo para refletir. Aprendem, sobretudo, por observação reflexiva e conceituação abstrata. São hábeis para criar modelos abstratos e teóricos, mas pouco preocupados com o uso prático dessas teorias. Utilizam raciocínio indutivo. Para ser efetivo com esse tipo de estilo, o professor deve funcionar como um especialista;

- Tipo 3 - Convergente (CA - EA) - Os aprendizes desse tipo respondem melhor quando têm oportunidade de trabalhar ativamente em tarefas bem definidas e aprendem por ensaio e erro, apoiando-se no ambiente quando se sentem inseguros. Para ser efetivo com esse estilo, o professor deve funcionar como um treinador, oferecendo um guia prático e feedback. Utilizam raciocínio dedutivo, com aplicação prática das idéias, são hábeis para definir problemas e tomar decisões. Sentem-se mais confortáveis lidando com conceituação abstrata e experimentação ativa;

- Tipo 4 - Conciliador ou Acomodador (EA - EC) - Esse tipo de aprendiz gosta de aplicar o material do curso numa nova situação, na resolução de problemas reais. Para ser efetivo, 
o professor deverá maximizar oportunidades para que os alunos possam descobrir coisas por eles mesmos. Os estudantes com esse estilo preferem aprendizagem baseada na experimentação ativa e na experiência concreta, fazendo coisas e enfrentando desafios.

A hipótese do Modelo de Kolb é que toda aprendizagem eficaz requer esse movimento cíclico dos quatro estilos de aprendizagem, embora cada indivíduo se sinta mais confortável em um dos estilos do ciclo, baseado na sua preferência na extensão das duas dimensões: percepção e processamento. Kolb (1985) desenvolveu, então, um instrumento de medida, denominado Inventário de Estilos de Aprendizagem (LSI - Learning Style Inventory), para identificar esses quatro estilos.

Analisando o trabalho de Kolb (1984), verifica-se que ele combinou as fases de desenvolvimento com os estilos de aprendizagem e propôs uma abordagem considerando a experiência de aprendizado, ao longo da vida, como composta por aquisição (até os 15 anos de idade), especialização (de 16 aos 40 anos) e integração (acima de 40 anos). Nesse sentido, o uso dessa abordagem representa uma alternativa para servir de base a um ambiente educacional melhor, adotando recursos e meios mais apropriados, levando em conta, principalmente, os traços dos alunos (aprendizes).

No Brasil encontram-se alguns trabalhos que utilizaram o instrumento de Kolb. Dentre eles está o de Cerqueira (2000) que vem sendo citado ao longo dessa pesquisa.

Cerqueira (2000) estudou os estilos de aprendizagem em 2.552 universitários de vários estados das cinco regiões do Brasil, contemplando cursos das oito áreas do conhecimento, utilizando-se do instrumento de Kolb.

No estudo procurou identificar a relação entre os estilos de aprendizagem dos estudantes e as variáveis: gênero, idade, semestres agrupados, região do Brasil e tipo de instituição e qual o estilo predominante nos estudantes de cada área. Concluiu que o estilo assimilador é predominante nos estudantes em todas as áreas do conhecimento e que os estilos 
de aprendizagem apresentaram diferenças estatisticamente significativas entre as faixas etárias, o agrupamento de semestres, a região e as áreas do conhecimento e não apresentaram diferenças relacionadas ao gênero e ao tipo de instituição.

\subsubsection{Myers-Briggs Type Indicator - MBTI}

De acordo com Kuri (2004, p. 50) Katharine Cook Briggs compartilhou com sua filha Isabel Briggs Myers o interesse pela obra Tipos Psicológicos de Carl Jung. Briggs e Myers trabalharam as idéias de Jung e incluíram mais uma preferência na identificação dos tipos psicológicos: a escolha entre uma atitude perceptiva e uma atitude julgadora como forma de viver e lidar com o mundo exterior.

Isabel Briggs Myers registrou em 1970, o relatório Introduction to type, propondo sua teoria ao estudar as formas distintas de se perceber (obter informação) e julgar (tomar decisões) dentre as pessoas.

Conforme a teoria, os tipos perceptivos estão sempre atentos para as chances de fazer as coisas que procuram, para as oportunidades e alternativas que lhe são viáveis, relutam em se envolver com agendas e programas, podendo perder prazos e deixar tarefas inacabadas, e fazem questão que o trabalho seja agradável e pertinente. De modo oposto, os tipos julgadores são criteriosos em relação a planos ou programas, envolvem-se com agendas de forma que, muitas vezes, não percebem as alternativas e opções que deixaram passar, acreditam que o trabalho vem antes de tudo, estabelecem prazos e cumprem.

Ainda de acordo com a teoria dos tipos, a personalidade está estruturada pelas quatro preferências que se referem às atitudes e ao uso das funções de percepção e julgamento (KURI, 2004: 53). O inventário Myers-Briggs Type Indicator (MBTI) classifica os indivíduos segundo suas preferências na escala composta de quatro dimensões: 1) orientação para vida 
(extrovertido / introvertido); 2) percepção (sensorial / intuitivo); 3) abordagens contratantes ao julgamento (reflexivos / sentimentais); 4) orientação em relação ao mundo externo (julgadores / perceptivos). O quadro 4 a seguir caracteriza cada um desses tipos.

\begin{tabular}{|c|c|}
\hline TIPO & $\begin{array}{l}\text { CARACTERÍSTICA } \\
\end{array}$ \\
\hline Extrovertido & Foco no mundo externo; experimenta as coisas, busca interação em grupos. \\
\hline Introvertido & Foco no mundo interno e das idéias; pensa sobre as coisas, prefere trabalhar sozinho. \\
\hline Sensorial & $\begin{array}{l}\text { É prático; seu foco está direcionado para os fatos e produtos; mostra-se mais } \\
\text { confortável com a rotina. }\end{array}$ \\
\hline Intuitivo & $\begin{array}{l}\text { É imaginativo; seu foco está voltado para significados e possibilidades. Prefere } \\
\text { trabalhar mais a nível conceitual; mostra aversão à rotina. }\end{array}$ \\
\hline Reflexivo & É objetivo; tende a tomar decisões baseadas na lógica e regras. \\
\hline Sentimental & $\begin{array}{l}\text { É subjetivo; tende a tomar decisões baseadas em considerações pessoais e } \\
\text { humanísticas. }\end{array}$ \\
\hline Julgador & Suas ações são planejadas e controladas; prefere seguir agendas. \\
\hline Perceptivo & Suas ações são espontâneas e procura se adaptar de acordo com as circunstâncias. \\
\hline
\end{tabular}

Quadro 4 - Indicador de Tipos Meyers-Briggs

Fonte: Adaptado de LOPES, 2002, p. 44.

Os escores nas quatro dimensões do MBTI podem ser combinados em 16 fórmulas de tipos possíveis, que fornecem combinações de letras da direção preferida em cada uma das quatro dimensões. Por exemplo, a combinação "INTP", que representa o tipo introvertido (I), intuitivo $(\mathrm{N})$, reflexivo $(\mathrm{T})$ e perceptivo $(\mathrm{P})$.

Claxton \& Murrell (1987) apud Cornachione Júnior (2004, p. 84) afirmam que diversas análises destacam que o MBTI pode, realmente, apoiar os professores a ajustarem o curso aos traços de seus alunos, alcançando, assim, melhores resultados. Além disso, os docentes podem se conscientizar sobre as conseqüências da existência (ou não) de combinação (apropriação) com os estilos de seus alunos ao longo do curso.

Conforme Kuri (2004, p. 93) é inevitável a presença de uma grande diversidade de estilos de aprendizagem nas salas de aula, contudo o problema não reside nas incompatibilidades que ocorrem algumas vezes entre professores e alunos, mas na falha em 
reconhecer e trabalhar os potencias conflitos e desentendimentos que prejudicam a aprendizagem.

\subsubsection{Modelo de estilos de aprendizagem de Felder-Silverman}

O modelo originalmente elaborado pelo Dr. Richard M. Felder, professor emérito de Engenharia Química da Universidade Estadual da Carolina do Norte, com a colaboração da Dra. Linda K. Silverman, psicóloga educacional, foi publicado em 1988. O trabalho definiu o Modelo de Felder-Silverman e identificou práticas de ensino de acordo com as necessidades dos alunos com diferentes estilos. Foi usado por instrutores e alunos de engenharia e ciências, embora tenha sido aplicado, subseqüentemente, em várias outras disciplinas. Uma apresentação melhorada do modelo foi trazida em 1993.

Felder realizou uma aplicação do modelo ao ensino de línguas (1995); uma validação do estudo dos índices de estilos de aprendizagem (2005); um estudo exploratório das diferenças dos estilos de aprendizagem, aproximação à aprendizagem e níveis de desenvolvimento intelectual (2005). Felder também publicou trabalhos que focalizam as dimensões individuais de diferentes estudantes (1989, 1990a, 1990b, 1991, 1994 e 1995a) e alguns relacionados a outros modelos de estilos de aprendizagem (1995b, 1996, 1998 e 2002).

O Modelo de Felder-Silverman (1988) e Felder (1993) contemplam cinco dimensões de estilos de aprendizagem: (1) processamento - Ativo/Reflexivo; (2) percepção Sensorial/Intuitivo; (3) entrada ou retenção - Visual/Verbal; (4) compreensão Seqüencial/Global e (5) organização - Indutivo/Dedutivo.

Dessas cinco dimensões, duas são réplicas de aspectos dos modelos de Kolb e MyersBriggs. A dimensão percepção (sensorial/intuitivo) é análoga à percepção de ambos - Kolb e Myers-Briggs - e a dimensão processamento (ativo/reflexivo) é encontrada também no 
Modelo de Kolb. Felder e Silverman acrescentaram mais três dimensões: entrada ou retenção

(visual/verbal), organização (indutivo/dedutivo) e compreensão (seqüencial/global).

Felder (1993), ao se referir às influências teóricas para elaboração de seu modelo,

afirma que:

\begin{abstract}
Enquanto formulava o modelo, eu estava fortemente influenciado pelo MBTI, e um pouco menos, pelo Kolb. Tive a idéia de incluir o aprendizado visual e auditivo através de textos sobre Programação Neuro-Lingüística (eu acreditava, e, ainda acredito, que o aprendizado sinestésico pertence à categoria de aprendizado ativo e não como sendo um aprendizado alternativo à forma visual e auditiva), e, posteriormente, mudei essa dicotomia para visual e verbal, baseado na minha intuição de que a prosa escrita funciona mais como informação auditiva do que como verdadeira informação visual. Mais tarde, encontrei bases para essa idéia nas literaturas sobre a Ciência Cognitiva, conforme expus no trabalho na minha página da internet referente aos estilos de aprendizagem no processo de ensino de língua estrangeira e segunda língua. A distinção seqüencial-global veio principalmente do trabalho da Dra. Silverman sobre o estudante visual/espacial (pode-se encontrar mais informações a respeito desse trabalho no seu website...), também reiterado pelo trabalho feito por Pask sobre estudantes seqüenciais e holísticos (descritos num volume de 1990 sobre estilos de aprendizagem, editado por Schmeck) e várias coisas sobre raciocínio (pensamento) do lado esquerdo e direito do cérebro, incluindo Hermann. (LOPES, 2002: 51-52) ${ }^{2}$
\end{abstract}

Conforme Felder e Silverman (1988), o estilo de aprendizagem de um estudante pode ser entendido, em grande parte, a partir das respostas a cinco questões básicas:

1) Qual informação é percebida preferencialmente pelo estudante?

Sensorial (externa) - imagens, sons, sensações físicas;

Intuitiva (interna) - possibilidades, intuição, dicas.

2) Através de qual canal sensorial a informação externa é recebida mais eficientemente?

Visual - diagramas, gráficos, desenhos;

Auditivo - palavras e sons.

3) Com qual organização da informação o estudante sente-se mais confortável?

Indutiva - fatos e observações são dados e princípios são inferidos;

Dedutiva - princípios são apresentados e as conseqüências são deduzidas.

\footnotetext{
${ }^{2}$ Trata-se da transcrição literal de um e-mail enviado para Lopes em 29/06/2001.
} 
4) Como o estudante prefere processar a informação?

Ativamente - através do envolvimento direto em atividades físicas ou em discussões; Reflexivamente - de um modo mais introspectivo.

5) Como o estudante estrutura a informação?

Sequencialmente - utilizando-se de uma seqüência de passos (linear);

Globalmente - por meio de mapas mentais e elos de ligação (não-linear).

O perfil do estilo de aprendizagem de um estudante fornece uma indicação dos prováveis pontos fortes e possíveis tendências ou hábitos que poderiam estar conduzindo a dificuldades na vida acadêmica.

De acordo com Lopes (2002, p. 54), Felder (1993) deixa claro que os estilos de aprendizagem são qualidades contínuas e não categorias únicas, e, como toda e qualquer medida de uma dimensão intrínseca ao sujeito, elas podem variar com o tempo, não devendo, por isso, ser consideradas como características estáticas, sofrendo, inclusive, influências das estratégias instrucionais adotadas, do conteúdo das disciplinas e do ambiente educacional.

Respondendo às cinco questões básicas, Felder e Silverman enumeram as características dos aprendizes de acordo com seus estilos de aprendizagem. São as dimensões do modelo:

\section{- Dimensão Sensorial / Intuitivo}

Aprendizes Sensoriais - gostam de resolver problemas através de procedimentos bem estabelecidos e não apreciam complicações e surpresas; são pacientes com detalhes; memorizam fatos com facilidade; apreciam trabalhos de manipulação, experimentais, repetitivos (laboratório); tendem a ser práticos e cuidadosos; não gostam de disciplinas que não têm uma conexão aparente com o mundo real.

Aprendizes Intuitivos - freqüentemente preferem descobrir possibilidades e interrelações; gostam de inovação e não apreciam a repetição; sentem-se confortáveis com 
abstrações e formulações matemáticas; são rápidos e criativos; não apreciam as disciplinas que envolvem muita memorização e cálculos rotineiros; apreciam a variedade.

\section{- Dimensão Visual / Verbal}

Aprendizes Visuais - lembram-se mais do que viram; substituem as palavras por símbolos; preferem as representações visuais - diagramas, quadros, cronogramas, gráficos, filmes e demonstrações; reconstroem imagens de diferentes modos.

Aprendizes Verbais - tiram mais proveito das explanações escritas e faladas; gostam de ouvir e de tomar notas; materiais de apoio impressos são úteis para eles; repetem as palavras, falando ou escrevendo; fazem a leitura de suas notas em silêncio; transformam diagramas em palavras.

\section{- Dimensão Indutivo / Dedutivo}

Aprendizes Indutivos - organizam a informação partindo do particular para o geral, com teorias ou idéias unificadoras, resultantes do estudo de situações individuais.

Aprendizes Dedutivos - organizam a informação onde as soluções e aplicações particulares são conseqüências de uma idéia geral. É um estilo verificado principalmente em assuntos técnicos e de organização do conhecimento adquirido.

\section{- Dimensão Ativo / Reflexivo}

Aprendizes Ativos - tendem a reter e compreender melhor a informação participando ativamente de alguma atividade - discutindo, aplicando ou explicando para outros; gostam do trabalho em grupo; são rápidos, mas podem ser precipitados.

Aprendizes Reflexivos - preferem refletir calmamente sobre a informação; podem ser mais lentos para iniciar uma atividade; gostam do trabalho individual ou em dupla.

\section{- Dimensão Seqüencial / Global}

Aprendizes Seqüenciais - avançam com entendimento parcial; ganham entendimento em passos lineares, com cada passo derivado do anterior; tendem a seguir caminhos lógicos e 
graduais na solução de um problema; têm facilidade para explicar; enfatizam a análise, os detalhes.

Aprendizes Globais - aprendem em grandes saltos, absorvendo o material quase que aleatoriamente, sem enxergar conecções, e repentinamente compreendem tudo; precisam do contexto, do grande quadro; são hábeis para resolver rapidamente problemas complexos; têm facilidade para juntar elementos, de maneiras novas, uma vez que tenham enxergado o grande quadro, mas podem ter dificuldade para explicar como fizeram isso; seu foco está na síntese, no pensamento sistêmico, holístico.

Nesse modelo, o resultado aponta a dimensão dominante entre os pares, que é expressa em três escalas: leve, moderada e forte.

É importante lembrar que o perfil levantado do aluno não reflete a sua adequação ou inadequação para uma determinada disciplina, curso ou profissão, mas ajuda a melhorar a aprendizagem, na medida em que o professor proponha, não só atividades que vão ao encontro do estilo preferencial de suas turmas, como também, escolha métodos instrutivos incompatíveis, a fim de poder estimular e fortalecer as habilidades menos desenvolvidas.

Quando o professor, na sua maneira de ensinar, privilegia exclusivamente o estilo preferencial dos estudantes, estes não desenvolvem a destreza mental que precisam para alcançar seu potencial de realização escolar e profissional. O desejável é o equilíbrio entre uma categoria e outra.

Soma-se a esse contexto a questão de que não só os alunos têm suas preferências de aprendizagem, mas também os professores têm suas preferências de ensinar, ou, em outras palavras, seus estilos de ensinar.

Desse modo, Felder e Silverman completam o trabalho de 1988, apresentando cinco perguntas que ajudam a definir os estilos de ensinar: 
1) Qual informação é enfatizada pelo professor: concreta (factual) ou abstrata (conceptual teórica)?

2) Que modo de apresentação é mais utilizado: visual (figuras, gráficos, diagramas, filmes, demonstrações) ou verbal (leituras, palestras, discussões)?

3) Como as apresentações são organizadas: de modo indutivo (o fenômeno leva aos princípios) ou de modo dedutivo (os princípios levam ao fenômeno)?

4) Qual a participação esperada do estudante: ativa (os estudantes se movem, falam, refletem) ou passiva (assistem e escutam)?

5) Sob qual perspectiva a informação é apresentada: sequiencial (progressão passo a passo - as árvores) ou global (contexto e relevância - a floresta)?

Todas essas informações são resumidas no quadro 5.

\begin{tabular}{|c|c|}
\hline Estilo de Aprendizagem & Estilo de Ensinar Correspondente \\
\hline $\left.\begin{array}{l}\text { sensorial } \\
\text { intuitivo }\end{array}\right\} \quad$ percepção & $\left.\begin{array}{l}\text { concreto } \\
\text { abstrato }\end{array}\right\} \quad$ ênfase da informação \\
\hline $\left.\begin{array}{l}\text { visual } \\
\text { verbal }\end{array}\right\} \quad$ entrada & visual \\
\hline $\left.\begin{array}{l}\text { indutivo } \\
\text { dedutivo }\end{array}\right\} \quad$ organização & $\left.\begin{array}{l}\text { indutivo } \\
\text { dedutivo }\end{array}\right\}$ \\
\hline $\left.\begin{array}{l}\text { ativo } \\
\text { reflexivo }\end{array}\right\}$ & participação do aluno \\
\hline $\left.\begin{array}{l}\text { sequencial } \\
\text { global }\end{array}\right\}$ & $\left.\begin{array}{l}\text { sequencial } \\
\text { global }\end{array}\right\}$ \\
\hline
\end{tabular}

Quadro 5 - Dimensões dos estilos de aprendizagem e dos estilos de ensinar

Fonte: FELDER e SILVERMAN, 1988, p. 675, tradução livre.

A desarticulação existente entre a maneira de ensinar e o estilo de aprendizagem dos estudantes, coloca o aluno numa situação de passividade, com poucas oportunidades de praticar e refletir sobre o que está sendo ensinado. Essa desarticulação prejudica o desempenho e as atitudes dos alunos tanto no curso, como no currículo e na carreira. Por 
outro lado, os professores deparam-se com notas baixas, falta de interesse dos alunos, hostilidade e pouca cooperação.

Felder (1993) sugere, então, que os cursos possam incluir momentos onde haja apresentação de conceitos, assim como suas conexões com o material relevante das experiências diárias dos estudantes (global); possam balancear teoria e modelos (intuitivo) com demonstrações e exemplos (sensorial); usem gravuras, diagramas, esboços (visual) para suplementar a informação (verbal); incluam números, bem como exemplos algébricos (sensorial, indutivo) para ilustrar conceitos abstratos (intuitivo, dedutivo); propiciem momentos para uma participação (ativo) e reflexão do material apresentado (reflexivo).

\section{6 Índice de Estilos de Aprendizagem de Felder-Soloman}

O Índice de Estilos de Aprendizagem (Index of Learning Styles - ILS) é um instrumento desenvolvido por Richard M. Felder e Barbara A. Soloman na Universidade Estadual da Carolina do Norte para determinar as preferências de aprendizagem em quatro dimensões do Modelo de Felder-Silverman (1988). Esse instrumento não contempla a dimensão (indutivo / dedutivo) do modelo.

O ILS abrange em cada uma das quatro dimensões, dois estilos opostos de aprendizagem: ativo ou reflexivo, sensorial ou intuitivo, visual ou verbal e seqüencial ou global. As respostas às questões do instrumento fornecem, para cada uma das quatro dimensões, dois escores que correspondem aos dois estilos abrangidos pela dimensão. A diferença entre os dois escores indica qual é, dentre os dois estilos, aquele que é predominante ou preferido pelo respondente.

A versão preliminar do ILS continha vinte e oito questões. Em 1994 e 1995, seus resultados foram submetidos à análise fatorial e alguns itens que não apresentaram uma 
discriminação perceptível foram substituídos. Revisado, o instrumento abrange quarenta e quatro questões de escolha forçada (alternativa a ou b), sendo onze questões para cada uma das quatro dimensões. Se as duas alternativas (a e b) se aplicarem igualmente, a escolha deve ser feita àquela mais freqüente.

O nível de predominância de estilo em pontuação de 1 ou 3 na escala indica "leve" preferência entre ambas as categorias da dimensão, ou seja, a preferência está praticamente equilibrada nos dois estilos; pontuação de 5 ou 7 na escala indica preferência "moderada" por uma das categorias; e a pontuação de 9 ou 11 na escala, indica "forte" preferência por uma das categorias da dimensão, como pode ser observado no quadro 6 .

\begin{tabular}{|c|c|c|c|c|}
\hline Escala & "Ativo / Reflexivo & Sensorial / Intuitivo & Visual / Verbal & Seqüencial / Global \\
\hline 11A ou 9A & $\begin{array}{c}\text { fortemente } \\
\text { ativo }\end{array}$ & $\begin{array}{c}\text { fortemente } \\
\text { sensorial }\end{array}$ & $\begin{array}{c}\text { fortemente } \\
\text { visual }\end{array}$ & $\begin{array}{l}\text { fortemente } \\
\text { sequiencial }\end{array}$ \\
\hline $7 \mathrm{~A}$ ou $5 \mathrm{~A}$ & $\begin{array}{c}\text { moderadamente } \\
\text { ativo }\end{array}$ & $\begin{array}{c}\text { moderadamente } \\
\text { sensorial }\end{array}$ & $\begin{array}{c}\text { moderadamente } \\
\text { visual }\end{array}$ & $\begin{array}{c}\text { moderadamente } \\
\text { seqüencial }\end{array}$ \\
\hline 3A ou 1A & $\begin{array}{c}\text { levemente } \\
\text { ativo }\end{array}$ & $\begin{array}{c}\text { levemente } \\
\text { sensorial }\end{array}$ & $\begin{array}{c}\text { levemente } \\
\text { visual }\end{array}$ & $\begin{array}{l}\text { levemente } \\
\text { seqüencial }\end{array}$ \\
\hline $1 B$ ou $3 B$ & $\begin{array}{l}\text { levemente } \\
\text { reflexivo }\end{array}$ & $\begin{array}{l}\text { levemente } \\
\text { intuitivo }\end{array}$ & $\begin{array}{c}\text { levemente } \\
\text { verbal }\end{array}$ & $\begin{array}{c}\text { levemente } \\
\text { global }\end{array}$ \\
\hline $5 B$ ou $7 B$ & $\begin{array}{c}\text { moderadamente } \\
\text { reflexivo }\end{array}$ & $\begin{array}{c}\text { moderadamente } \\
\text { intuitivo }\end{array}$ & $\begin{array}{c}\text { moderadamente } \\
\text { verbal }\end{array}$ & $\begin{array}{c}\text { moderadamente } \\
\text { global }\end{array}$ \\
\hline 9B ou 11B & $\begin{array}{c}\text { fortemente } \\
\text { reflexivo }\end{array}$ & $\begin{array}{c}\text { fortemente } \\
\text { intuitivo }\end{array}$ & $\begin{array}{c}\begin{array}{c}\text { fortemente } \\
\text { verbal }\end{array} \\
\end{array}$ & $\begin{array}{c}\text { fortemente } \\
\text { global }\end{array}$ \\
\hline
\end{tabular}

Quadro 6 - Classificação de acordo com o Índice de Estilos de Aprendizagem

O instrumento tem ainda um cabeçalho onde o respondente deve colocar: sexo, escolaridade e instituição.

Lopes (2002, p. 57) cita e utiliza em seu estudo a primeira versão da tradução do instrumento para o português, realizada por Marcius F. Giorgetti e Nídia Pavan Kuri da Escola de Engenharia de São Carlos da Universidade de São Paulo - EESC/USP.

A escolha por esse instrumento está relacionada à sua acessibilidade, confiabilidade e validade.

Acessibilidade porque, para facilitar uma grande coleta de dados dos estilos de aprendizagem dos estudantes, foi desenvolvida uma base de dados, que está hospedada no 
servidor do Departamento de Engenharia de Produção da EESC/USP no seguinte endereço: http://www.prod.eesc.usp.br/aprendizagem/. Nesse departamento há um grupo de pesquisa Grupo de Pesquisa Aprendizagem em Engenharia (APRENDE) - trabalhando com estilos de aprendizagem que obteve a autorização do Dr. Richard Felder para utilizar o ILS.

Os pesquisadores e desenvolvedores deste projeto, professor Dr. Renato Vairo Belhot, professor Dr. Reginaldo Santana Figueiredo e professor Dr. Marcius F. Giorgetti autorizaram o uso do questionário eletrônico nessa pesquisa, fornecendo uma senha de acesso para o mapeamento dos estilos de aprendizagem dos alunos do curso de graduação em Contabilidade da FEA-RP.

No que diz respeito à confiabilidade e validade foram localizados alguns trabalhos publicados que testaram o instrumento no exterior e no Brasil.

Zywno (2003) apresentou um estudo que fornece uma análise das propriedades psicométricas do ILS baseada nos escores de questionários válidos, respondidos por estudantes e professores de engenharia da Ryerson University em Toronto, Canadá. A análise incluiu teste e re-teste de confiabilidade, confiabilidade interna, correlação item total e correlação inter-escala.

A análise teste e re-teste dos escores do ILS sugeriu uma confiabilidade de forte a moderada em todas as escalas. A confiabilidade interna alcançou resultado satisfatório em comparação com o estudo de Livesay et al. (2002) e as análises de correlação sugeriram que as escalas do modelo definem qualidades separadas, assim como teoricamente previsto. Houve uma evidência de sobreposição entre as dimensões sensorial/intuitivo e seqüencial/global, também observada no estudo de Livesay et al. (2002).

Livesay et al. (2002) concluíram que o ILS é uma ferramenta apropriada e estatisticamente aceitável para caracterizar as preferências de aprendizagem. Os autores utilizaram o ILS para caracterizar as preferências de aprendizagem de acordo com as 
intenções do autor do modelo, que indicou seu uso para fornecer aos professores e estudantes uma alternativa de se aproximarem dentro do processo de ensino-aprendizagem, ou seja, aproximar os estilos de ensinar aos estilos de aprender por meio de estratégias adequadas.

Em sua conclusão, Zywno (2003) concorda com Livesay et al. (2002) ao afirmar que o ILS é uma ferramenta psicométrica adequada para identificar estilos de aprendizagem, destacando, também, a acessibilidade ao instrumento que foi, inclusive, traduzido em diversos idiomas. Ressalta, ainda, que são necessários muitos estudos com diferentes amostras e dados para assegurar a confiabilidade e a validade de qualquer instrumento e, por isso, sugere que as pesquisas devem continuar.

Felder e Spurlin (2005) publicaram um estudo que fornece um primeiro exame compreensivo do ILS incluindo respostas a diversas questões e conclusões sobre confiabilidade e validade de várias pesquisas conduzidas pelo uso do ILS.

Na compilação de estudos que fizeram, esses autores concordaram com a afirmação de Livesay et al. (2002) e Zywno (2003) de que o ILS é um instrumento confiável, válido e adequado para identificação dos estilos de aprendizagem, embora seja recomendado que as pesquisas com tal instrumento continuem a ser realizadas.

No Brasil destacam-se os trabalhos de Lopes (2002) e Kuri (2004).

Lopes (2002) realizou uma pesquisa com 449 estudantes de Ciências Humanas e Ciências Exatas de dois centros universitários de Belo Horizonte, onde procurou mostrar a complexidade da relação: características individuais e o processo de ensino-aprendizagem. $\mathrm{O}$ objetivo do estudo foi investigar a validade do ILS de Felder-Soloman.

Os resultados mostraram que alguns itens apresentaram discordância entre sua pertinência e a dimensão de estilos que pretendem investigar e sugeriram um estudo de validação semântica e revisão dos itens comprometidos a partir daqueles que melhor estão 
discriminando os sujeitos no que diz respeito às quatro dimensões de estilos propostas pelo instrumento.

Kuri (2004) aplicou o ILS de Felder-Soloman e o Classificador de Temperamentos de Kersey a 840 alunos de graduação em Engenharia, matriculados e com freqüência regular nas habilitações Civil, Mecânica, Elétrica e Produção, da Escola de Engenharia de São Carlos da Universidade de São Paulo, com o objetivo de avaliar como o ensino de Engenharia pode se beneficiar do conhecimento dos tipos de personalidade e estilos de aprendizagem dos estudantes.

O estudo comprovou a confiabilidade e validade dos instrumentos utilizados, que se mostraram capazes de estimar as preferências da população investigada e demonstrou como o conhecimento dos traços de personalidade e estilos de aprendizagem dos estudantes traz implicações importantes para o ensino, pois pode auxiliar o docente no planejamento de suas atividades, eliminar barreiras de comunicação nas salas de aula, promover relacionamentos mais abertos e evitar perdas de produtividade.

Com relação à aplicação do ILS de Felder-Soloman no ensino de Contabilidade no Brasil, pode-se destacar o trabalho de Bertolini (2005).

Bertolini (2005) investigou o impacto dos estilos de aprendizagem no desempenho acadêmico de 84 alunos entre o primeiro e o nono semestre do curso de graduação em Contabilidade da FEA-RP/USP, relacionando o perfil dos estilos dos alunos às notas obtidas em disciplinas de matemática financeira e ciências exatas e disciplinas ligadas diretamente à Contabilidade. Pelas análises comparativas realizadas, o trabalho levou a conclusão de que os estilos de aprendizagem não interferiram no desempenho acadêmico dos alunos.

Com a intenção de verificar melhor a existência ou não do impacto dos estilos de aprendizagem no desempenho acadêmico dos alunos no curso de Contabilidade da FEA-RP, esse trabalho optou por abranger uma amostra maior de estudantes e incluir na análise os 
estilos de aprendizagem dos professores e os estilos das disciplinas. Desse modo, pode colaborar com a ciência, inovando e trazendo conclusões baseadas numa avaliação composta de mais elementos.

Para a seção seguinte foram selecionados alguns trabalhos sobre estilos de aprendizagem na Contabilidade, tanto no exterior como no Brasil, que se utilizaram de outros instrumentos de avaliação dos estilos.

\subsection{Estilos de aprendizagem e ensino de Contabilidade}

A aplicação dos estilos de aprendizagem no ensino de Contabilidade tem sido mais expressiva no exterior. A seguir são destacadas algumas dessas experiências e, também, uma experiência brasileira.

Duff (2004) descreve a utilização do instrumento CLS (cognitive learning styles) para educadores de Contabilidade e seu potencial para ajudar os alunos em seu próprio processo de aprendizagem. Seu trabalho relata o uso dos estilos de aprendizagem cognitivos no ensino contábil e considera modelos promissores aqueles que tentam relacionar características individuais e experiências para explicar desempenho.

O autor relata cinco proposições para os educadores contábeis usarem o CLS e medidas associadas para ajudar o aluno "aprender a aprender". As três primeiras proposições relacionam os estilos a métodos de instrução apropriados e estratégias de aprendizagem para levar os estudantes a um melhor desempenho e aumentar a capacidade deles para "aprender a aprender".

A quarta proposição diz que os educadores de Contabilidade devem reconhecer que a qualidade da aprendizagem é diretamente influenciada pelas preferências de aprendizagem dos estudantes. E a quinta proposição afirma que os educadores contábeis, ao utilizarem 
medidas de estilos de aprendizagem, têm a capacidade de identificar alunos com estratégias de estudo ineficazes, as quais prejudicam o desempenho acadêmico e aumentam a probabilidade de os alunos deixarem o curso.

Wolk e Nikolai (1997) utilizaram o instrumento MBTI em um estudo exploratório para mensurar as preferências de 94 pós-graduandos, 152 graduandos e 98 professores da área contábil no período de 1991 a 1994 em Universidades do Midwestern. Os resultados indicaram algumas diferenças nos tipos classificados pelo MBTI entre os três grupos, as quais têm implicações nos programas de contabilidade.

Os estudantes de Contabilidade foram identificados como predominantemente extrovertidos, sensoriais, pensadores e julgadores. O corpo docente foi identificado como composto predominantemente pelos tipos, introvertidos, sensoriais, pensadores e julgadores.

A discussão trata de possíveis mudanças nos métodos de ensino de acordo com os tipos identificados e os autores concluem que o fato de estudantes e professores conhecer cada tipo pode trazer valiosas contribuições para as aulas e para a profissão, tais como produtividade e qualidade.

Ramsay, Hanlon e Smith (2000) também utilizaram o MBTI, que, neste caso, foi aplicado a 132 alunos de Contabilidade da Monash University Clayton, campus Victoria, Austrália. O estudo mostra a relação entre o estilo cognitivo (medido pelo MBTI) e as preferências para aprendizado e sugere que a educação contábil poderia prover aos alunos diversas abordagens de aprendizagem, permitindo a eles uma alternativa mais adequada a seu estilo cognitivo.

Eide, Geiger e Schwartz (2001) desenvolveram uma pesquisa utilizando o instrumento Canfield LSI para identificar os estilos de aprendizagem de 531 alunos de Contabilidade de oito universidades dos Estados Unidos. 
Os autores realizaram uma avaliação crítica das propriedades psicométricas do Canfield LSI. Aplicaram duas versões do instrumento, avaliando a confiabilidade interna, estabilidade de classificação e validade.

Foi encontrada uma consistência interna moderada e uma instabilidade substancial de classificação entre duas aplicações. Em termos de validade também foram encontradas inconsistências.

Os autores concluíram com que um suporte teórico limitado e com uma carência de justificativa empírica, é pouco aconselhável o uso do Canfield LSI na pesquisa sobre educação contábil.

McKee, Mock e Ruud (1992) realizaram um trabalho utilizando o instrumento de Kolb em uma amostra de estudantes de Contabilidade dos Estados Unidos e da Noruega. Os autores encontraram diferenças significativas nos estilos de aprendizagem dos estudantes de ambos os países e exploraram, também, as implicações que isso traz na educação e na prática dos dois países.

Os resultados indicaram que o estilo predominante nos estudantes de Contabilidade noruegueses é o assimilador, que contrasta com os estudantes dos Estados Unidos, nos quais o estilo predominante é o convergente. Isso significa que os estudantes de Contabilidade dos Estados Unidos aprendem mais efetivamente em algumas circunstâncias do que os noruegueses e vice-versa.

Os autores dizem não ter uma resposta definitiva para a questão do motivo dessa diferença, mas colocam a opinião de que possa ser decorrente do fato de a educação contábil norueguesa ser mais teórica e conceitual e a educação contábil americana ser mais prática.

Eles deixam claro que a constatação tem relevância para o cenário de educação contábil internacional, principalmente no desenvolvimento de programas educacionais ou de treinamento para uso na $w e b$, pois tais programas não devem privilegiar apenas um estilo e 
sim se preocupar em variar os métodos. Outra implicação seria para os contadores que trabalham em nível internacional, que teriam que superar, além da barreira da língua, a dos estilos de aprendizagem. Os contadores dos Estados Unidos, que trabalham com contadores de outros países, como da Noruega, precisam fazer ajustes para um diferente estilo de aprendizagem, assim como para uma língua diferente.

Nesse estudo ainda são citados trabalhos de outros autores, os quais afirmam que a pesquisa em psicologia educacional vem demonstrando que a adaptação de métodos instrucionais e estratégias de ensino de acordo com características individuais chave, incluindo os estilos de aprendizagem, tem levado a uma melhora no desempenho.

Outro trabalho que trouxe contribuições utilizando o instrumento de Kolb é o de Collins e Milliron (2001), onde foram avaliados 334 profissionais contábeis. Esse estudo evidencia estilos predominantes nos profissionais contábeis, embora constate uma grande homogeneidade na amostra pesquisada, e coloca em questão se a diversidade seria a melhor opção para o futuro profissional.

Os resultados sugerem que o estilo predominante entre os profissionais contábeis é o convergente, tendo encontrado uma concentração ainda maior de convergentes entre os profissionais mais avançados. Esses resultados trazem implicações tanto para os educadores contábeis, que podem usar o instrumento de avaliação de estilos de aprendizagem como uma ferramenta para prever o sucesso dos futuros profissionais, como para os empregadores, que podem utilizá-lo para recrutamento e contratação de profissionais.

Entretanto, os pesquisadores mostram que se deve tomar cuidado com essas conclusões, pois existem opiniões opostas, que afirmam que contradições e obstáculos são condições necessárias para o desenvolvimento individual e da criatividade.

Os autores deixam algumas questões a serem esclarecidas por futuras pesquisas, tais como, se a natureza do trabalho contábil influencia o estilo de aprendizagem dos profissionais 
na prática, como os estilos de aprendizagem podem afetar a promoção e o desempenho dos contadores na prática, se o estilo convergente dos profissionais que ocupam posições administrativas pode ser modificado através da educação continuada e se a homogeneidade de estilos deve ser promovida ao invés da diversidade.

No Brasil pode ser citado o trabalho de Cornachione Junior (2004) que se destaca como um dos principais trabalhos acadêmicos brasileiros nessa área. Cornachione Junior estudou as tecnologias da educação nos cursos de Ciências Contábeis e, segundo o autor, ao conhecer os estilos de aprendizagem dos alunos, os professores têm maiores chances de sucesso no alcance de seus objetivos.

Cornachione Junior relata que o conjunto de valores e cultura da sociedade e da instituição educacional exerce enorme influência no desenvolvimento das atividades. Nesse sentido, o autor afirma a necessidade de considerar o perfil das pessoas envolvidas instituição, alunos e professores - principalmente com respeito a alguns fatores, dentre os quais, os estilos de aprendizagem, para o êxito na implementação e aplicação de determinada modalidade educacional.

Como pode ser observado, diversas pesquisas têm sido conduzidas no sentido de identificar e utilizar os estilos de aprendizagem como uma alternativa para o aprimoramento e emprego de estratégias de ensino e métodos instrucionais adequados, pelos professores e profissionais de Contabilidade, para auxiliá-los no alcance de seus objetivos. Para os alunos, é destacada a importância de se adotar estratégias de aprendizagem para melhorar o aproveitamento e o desempenho.

É possível constatar, também, que nem sempre o emprego de determinados instrumentos de avaliação dos estilos de aprendizagem é bem sucedido, fazendo com que os pesquisadores desaconselhem o uso ou sugiram modificações nos seus componentes. 
Todos esses trabalhos ajudam a reforçar o objetivo central dessa pesquisa que é avaliar se os estilos de aprendizagem impactam no desempenho acadêmico dos alunos do curso de Contabilidade da FEA-RP, por meio da identificação dos estilos dos alunos, professores e disciplinas e sua confrontação com o desempenho acadêmico, trazendo, desse modo, novas contribuições para a Ciência e para o ensino de Contabilidade. 


\section{ENSINO DE CONTABILIDADE}

Conforme Iudícibus (2004) os estudos envolvendo a Contabilidade fizeram surgir duas escolas principais: a Escola Européia ou Italiana e a Escola Norte Americana. Na Europa eram três escolas do pensamento contábil: a primeira, chefiada por Francesco Villa, foi a Escola Lombarda ou Administrativa; a segunda, a Escola Toscana ou Personalista, chefiada por Giusepe Cerboni; e a terceira, a Escola Veneziana ou Controlista, por Fábio Bésta. Nessa época, na Itália, a Contabilidade já tinha chegado à universidade, sendo lecionada com a aula de comércio da corte, em 1809.

A obra de Francesco Villa foi escrita para participar de um concurso sobre Contabilidade, promovido pelo governo da Áustria, que havia reconquistado a Lombarda, terra natal do autor. Além do prêmio, Villa teve o cargo de Professor Universitário.

Francesco Villa extrapolou os conceitos tradicionais de Contabilidade, segundo os quais escrituração e guarda de livros poderiam ser feitas por qualquer pessoa inteligente. Para ele, a Contabilidade implicava conhecer a natureza, os detalhes, as normas, as leis e as práticas que regem a matéria administrada, ou seja, o patrimônio. Era o pensamento patrimonialista.

Giusepe Cerboni foi um dos primeiros autores que procuraram elevar a Contabilidade a um ramo de conhecimento científico, tentando superar o conceito de simples arte de registro do ter e do contar (SCHMIDT, 2000: 70).

Fábio Bésta, seguidor de Francesco Villa, superou o mestre em seus ensinamentos. Demonstrou o elemento fundamental da conta, o valor, e chegou muito perto de definir patrimônio como objeto da Contabilidade.

Contudo, foi Vicenzo Mazi, seguidor de Fábio Bésta, quem pela primeira vez, em 1923, definiu patrimônio como objeto da Contabilidade. O enquadramento da Contabilidade 
como elemento fundamental da equação aziendalista, teve, sobretudo, o mérito incontestável de chamar atenção para o fato de que a Contabilidade é muito mais do que mero registro; é um instrumento básico de gestão.

Entretanto, segundo Iudícibus (2004) a escola Européia teve peso excessivo da teoria, sem demonstrações práticas, sem pesquisas fundamentais. A exploração teórica das contas e o uso exagerado das partidas dobradas, inviabilizando, em alguns casos, a flexibilidade necessária, principalmente, na Contabilidade Gerencial, preocuparam-se demais em demonstrar que a Contabilidade era uma ciência ao invés de dar vazão à pesquisa séria de campo e de grupo.

Talvez a crítica à escola Italiana tenha sido dura, mas, apesar de tudo, o saldo deixado por ela e pelos demais europeus, entre os quais, os alemães e os ingleses, estes últimos na parte de auditoria, é altamente positivo. Os italianos e alemães quiseram dar a Contabilidade uma roupagem excessivamente vistosa, porém, assim mesmo, conseguiram, na época, vender ao mundo esta imagem.

Esse conjunto de fatores desfavoráveis acentuou-se a partir de 1920, com a ascensão econômica e cultural do colosso norte-americano. Enquanto declinavam as escolas européias, floresciam as escolas norte-americanas com suas teorias e práticas contábeis, favorecidas não apenas pelo apoio de uma ampla estrutura econômica e política, mas também, pela pesquisa e trabalho sério dos órgãos associativos.

De acordo com Hendriksen \& Breda (1999) o surgimento do American Institute of Certified Public Accountants foi de extrema importância no desenvolvimento da Contabilidade e dos princípios contábeis. Várias associações empreenderam muitos esforços e grandes somas em pesquisas nos Estados Unidos. Havia uma total integração entre acadêmicos e os já profissionais da Contabilidade, o que não ocorreu com as escolas européias, onde as universidades foram decrescendo em nível e em importância. 
A criação de grandes empresas, como as multinacionais ou transnacionais, por exemplo, que requerem grandes investimentos de capital, de muitos acionistas, foi a principal causa do estabelecimento das teorias e práticas contábeis que permitissem a correta interpretação das informações por qualquer acionista ou outro interessado, em qualquer parte do mundo.

No início do século atual, surgiram as gigantescas corporations, e este fato, aliado ao enorme desenvolvimento do mercado de capitais e ao extraordinário ritmo de desenvolvimento que os Estados Unidos da América experimentou e ainda experimenta, constituiu um campo fértil para o avanço das teorias e práticas contábeis.

Considerando o progresso já alcançado, as enormes quantias ainda investidas na pesquisa contábil e a posição de potência econômica mundial que ainda sustenta, a escola Norte Americana dificilmente deixará de continuar a produzir notáveis progressos na disciplina.

A Contabilidade brasileira no período anterior a 1964 é marcada fundamentalmente pela intervenção da legislação em seus procedimentos e pela influência doutrinária das escolas italianas. Contudo, conforme Schmidt (2000, p. 210), a partir da adoção do método didático norte-americano pela USP, em 1964, o direcionamento doutrinário contábil, especialmente do maior centro de pesquisa contábil nacional, o Departamento de Contabilidade e Atuária da FEA-USP, muda definitivamente, abandonando as escolas de pensamento contábil italianas e assumindo os ditames da escola norte americana

Ainda de acordo com Schmidt, embora não exista uma escola de pensamento contábil genuinamente brasileira, é possível destacar várias colaborações de pensadores contábeis nacionais, aliadas à permanente participação dos legisladores, para o desenvolvimento da prática e da teoria contábil no país. O ano de 1966 ficou marcado no Brasil por uma das 
maiores contribuições nacionais à comunidade contábil internacional, a chamada escola de correção monetária.

Na sequiência são expostos alguns fatos marcantes do desenvolvimento da profissão contábil no Brasil. Como fontes de pesquisa têm-se os trabalhos de Watanabe (1996), Schmidt (2000), Iudícibus e Ricardino Filho (2002), Ericeira (2003), Iudícibus (2004) e Peleias \& Bacci (2004).

\subsection{A profissão contábil no Brasil}

De acordo com Watanabe (1996, p. 5), desde o Brasil-Colônia, passando pelo período da República Velha e pelo início do século XX até o ano de 1946, registra-se a criação de instituições de ensino e de defesa profissional, a ocorrência de movimentos classistas congressos e convenções - e a criação oficial do órgão registrador e fiscalizador da profissão contábil no Brasil.

Em 1754, o governador Francisco Xavier de Mendonça Furtado, irmão do futuro Marquês de Pombal, propôs a formação profissional do contador. Assim, foi criada a Aula de Comércio no Brasil, sob a supervisão da Junta de Comércio de Lisboa. Naquela época, a expressão aula correspondia à academia o que mais tarde se denominou escola superior ou faculdade.

No ano de 1756, a Aula de Comércio teve sua previsão legal pelo artigo XVI dos Estatutos da Junta do Comércio de Lisboa e foi aprovada pelo decreto de 12 de dezembro desse mesmo ano.

A Ordem Régia, de 18 de janeiro de 1764, tornou obrigatório o registro por partidas dobradas. A Carta de Lei datada de 30 de agosto de 1770 estabeleceu a matrícula dos GuardaLivros diplomados de Aula de Comércio da Junta de Comércio de Lisboa. Foi a primeira 
regulamentação da profissão contábil dispondo sobre privilégios dos diplomados em domínios portugueses e, portanto, no Brasil Colônia.

Em 1804, José da Silva Lisboa, intitulado Visconde de Cairu, fez publicar a obra "Princípios de Economia Política". Por meio de alvará publicado em 23 de agosto de 1808, criou-se a Real Junta de Comércio, Agricultura, Fábricas e Navegação e foi determinada a adoção do sistema de partidas dobradas para controle dos bens.

Conforme Peleias \& Bacci (2004, p. 41) o ano de 1809 apresenta dois fatos relevantes: a promulgação do Alvará de 15 de julho, criando oficialmente o ensino de Contabilidade no país, por meio das aulas de comércio, intituladas aulas práticas, e o segundo, a apresentação, pelo Visconde de Cairu, de um sistema de Direito Comercial, juntamente com a realização dos primeiros estudos sobre Economia Política no Brasil.

Em 1833, a obra A Metafísica da Contabilidade Comercial, escrita por Estevão Rafael de Carvalho, divulgava o método das partidas dobradas e propunha a elevação da Contabilidade à condição de Ciência. Segundo Ericeira (2003, p. 54) essa obra teve ampla divulgação, entretanto, não houve interessados em sua aquisição.

Por meio do Decreto $\mathrm{n}^{\circ} 456$, de 23 de julho de 1846, foi fixado o regulamento das aulas de comércio, com duração estabelecida em dois anos, e cujos exames finais abordavam as disciplinas de Matemática, Geografia, Economia Política, Direito Comercial, Prática das Principais Operações e Atos Comerciais.

A promulgação do primeiro Código Comercial Brasileiro por meio da Lei $\mathrm{n}^{\circ} 556$, de 25 de junho de 1850, trouxe a obrigatoriedade de as empresas manterem a escrituração contábil, seguirem uma ordem uniforme para os registros contábeis e o levantamento, ao final de cada ano, dos balanços gerais.

A determinação do uso das partidas dobradas reforçou a necessidade do ensino comercial e em 1856 surgiu o Instituto Comercial do Rio de Janeiro, que a partir de 1863, 
passou a oferecer a disciplina Escrituração Mercantil, buscando qualificar seus alunos ao exercício da escrituração contábil.

No dia 22 de agosto de 1860 foi promulgada a Lei $\mathrm{n}^{\circ} 1.083$, que estabeleceu para as empresas da época, a obrigatoriedade de publicar e de remeter ao governo, nos prazos e conforme seus regulamentos, os balanços, demonstrações e documentos por este determinados. Essa lei foi regulamentada pelo Decreto $\mathrm{n}^{\mathrm{o}} 2.679$, de 03 de novembro do mesmo ano, que definiu as datas máximas para a publicação de balanços e para quais órgãos as empresas deveriam enviar as referidas demonstrações contábeis.

De acordo com Iudícibus e Ricardino Filho (2002, p. 7) a Lei no 1.083 é de fato a primeira Lei das Sociedades por Ações no Brasil e tornou público os padrões contábeis nacionalmente adotados, até que a Lei nº 2.627/40 apresentasse outras disposições.

O Decreto Imperial $n^{\circ} 4.475$ de 18 de fevereiro de 1870 reconheceu oficialmente a Associação dos Guarda-Livros da Corte, tornando o guarda-livros uma das primeiras profissões liberais regulamentadas no Brasil.

Em 1890, a Escola Politécnica do Rio de Janeiro passou a oferecer a disciplina Direito Administrativo e Contabilidade, relacionada à escrituração mercantil, associando, pela primeira vez no Brasil, a Contabilidade ao Direito.

Conforme Mancini (1978) apud Peleias \& Bacci (2004, p. 43) no ano de 1891 registrou-se o funcionamento da Academia de Comércio de Juiz de Fora, Minas Gerais. Na cidade de São Carlos, instalou-se em 1892, um sistema de Contabilidade Pública, de característica patrimonial, financeira e orçamentária, usando o método das partidas dobradas. Esse sistema obteve pleno êxito e, no início do século XX (por volta de 1905), foi implantado no Tesouro do Estado, por meio da reforma da escrituração estadual. O mesmo sucesso ocorrido em São Carlos deu-se no Estado de São Paulo, e o sistema tornou-se o padrão adotado no Brasil, com a criação da Contadoria Central da República, em 1922. 
De acordo com Iudícibus (2004, p. 41) a primeira escola especializada no ensino da Contabilidade foi a Escola de Comércio Álvares Penteado, criada em 1902, que produziu alguns professores excelentes, como Francisco D’Auria, Frederico Herrmann Júnior, Coriolano Martins, dentre outros.

D’Áuria e Herrmann Jr. participaram ativamente do reconhecimento da profissão contábil no País e da criação das primeiras entidades de classe dos contabilistas: o Instituto Paulista de Contabilidade (atual Sindicato dos Contabilistas de São Paulo) e a Academia Paulista de Contabilidade. Em suas obras, ambos entendiam ser a Contabilidade uma ciência. Além deste posicionamento, contribuíram para a criação da Revista Brasileira de Contabilidade em 16 de dezembro de 1911.

O primeiro número da revista trouxe, à página 2 , um ensaio de classificação científica sobre contas comerciais, escrito por José da Costa Sampaio, aqui considerado um dos primeiros estudos científicos sobre Contabilidade produzido no Brasil. A Revista Paulista de Contabilidade, com seu primeiro número editado em junho de 1922, substituiu a Revista Brasileira de Contabilidade, com o objetivo de publicar não só artigos técnicos, mas também defender as causas nobres que resultassem em benefício dos contadores e guarda livros brasileiros.

Em 1920, tramitou no Senado Federal o projeto de lei de autoria do Senador Raymundo de Miranda, determinando que toda a escrituração comercial fosse realizada pelo sócio autorizado pelo contrato social ou por guarda-livros habilitado.

A primeira discussão sobre harmonização e padronização contábil no Brasil, com a participação da classe contábil, ocorreu em 1926, e as primeiras alterações na regulamentação ocorreram em 1940, com inovações significativas. A primeira se referindo às normas sobre a Contabilidade Pública dos Estados e Municípios e a segunda tratando das sociedades anônimas. 
Os benefícios dessa padronização foram fundamentais na análise comparativa das demonstrações contábeis das empresas, pois permitiram a construção de séries históricas, evidenciando os resultados da atividade empresarial ao longo do tempo. Outro benefício importante foi com relação ao estudo da Contabilidade, contribuindo para que as instituições de ensino superior pudessem oferecer à sociedade, profissionais com maiores qualificações técnicas.

Nas décadas de 30 e 40 do século XX ocorreram ações relativas à exigência da assinatura do profissional contábil em livros e documentos das empresas, novas ações governamentais que buscaram a padronização contábil, a equiparação de direitos em função da regulamentação exigida pelo novo cenário e a criação dos principais órgãos de classe da profissão contábil no País.

O Decreto Lei n 21.033/32 estabeleceu as novas condições para o registro de contadores e guarda-livros e tornou obrigatória a assinatura dos livros comerciais, cumprindo determinações do Código Comercial e da Lei de Falências vigentes à época. As ações citadas, regulamentadas e equiparadas pelo Decreto Lei, permitiram a diversos profissionais atuantes antes de sua promulgação, o direito de exercerem a profissão regulamentada de Contador. O título de contador foi instituído oficialmente pelo Decreto $\mathrm{n}^{\circ} 17.329$ de 1926, àqueles que concluíram o curso geral e o curso superior de Ciências Econômicas e Comerciais ${ }^{3}$.

Em 1931, foram estruturados os cursos técnicos de Atuária e de Perito Contador e o curso superior de Administração e Finanças. O curso superior de Ciências Contábeis somente foi criado em 22 de setembro de 1945, pelo Decreto Lei n $^{\circ} 7.988$. Deve-se destacar que, na realidade, o citado Decreto-Lei criou o curso de Ciências Contábeis e Atuariais, conferindo aos formandos o grau de Bacharel em Ciências Contábeis e Atuariais. Numa análise legal e crítica, a criação dos cursos de Ciências Contábeis se deu efetivamente com o advento da Lei

\footnotetext{
${ }^{3}$ Informações disponíveis em: www.portaldecontabilidade.com.br. Acesso em 30/08/2005.
} 
n 1.401 de 31 de julho de 1951, que desdobrou o curso de Ciências Contábeis e Atuariais em dois, possibilitando aos concluintes receberem o título de Bacharel em Ciências Contábeis.

Em 1946 foi criada a Faculdade de Ciências Econômicas e Administrativas da Universidade de São Paulo, que inseriu em seu corpo docente alguns professores egressos da Escola de Comércio Álvares Penteado.

Em 27 de maio de 1946 foi promulgado o Decreto Lei $\mathrm{n}^{\circ}$ 9.295/46, criando o CFC Conselho Federal de Contabilidade, e os CRCs - Conselhos Regionais de Contabilidade. Esses órgãos, operando sob a coordenação do CFC, atuam na fiscalização do exercício da profissão contábil, colaboram na definição de normas e procedimentos contábeis, por meio da promulgação das Normas Brasileiras de Contabilidade, funcionam como tribunais de ética e definem, regulamentam e baixam normas e padrões de interesse da profissão contábil, além de estabelecerem e efetuarem o recolhimento das taxas relativas ao registro e exercício profissional.

Os anos 60 reservaram profundas mudanças na postura educacional do país, muito em função da ditadura militar de 1964. Em 1968, entrou em vigor a Lei $n^{\circ} 5.540$, que reformou o ensino universitário, criando a departamentalização e a matrícula por disciplina. Por essa época, já existiam cursos de licenciatura em Contabilidade que preparavam profissionais para lecionar nos cursos técnicos em Contabilidade.

$\mathrm{Na}$ verdade, na maioria dos casos, não era interessante para grande parte dos profissionais da área contábil direcionar-se para a educação em Contabilidade, sendo-lhes mais rentável, ainda que com inúmeros problemas, trabalhar em escritórios ou departamentos de Contabilidade das empresas.

Na década de 70 e, principalmente, a partir da década de 80, os órgãos de classe e associações ligadas à profissão tiveram uma maior atuação na emissão de pronunciamentos sobre assuntos contábeis e também sobre os profissionais e o ensino superior. 
Foi na década de 90 que se evidenciaram questões da educação continuada. A reforma do currículo de Ciências Contábeis por meio da Resolução nº 03/92, criou um currículo mínimo para o curso, esperando, com isso, contribuir para uma melhor qualificação dos futuros profissionais de Ciências Contábeis. Entre as determinações que emanavam daquela resolução, estavam a inclusão no currículo de disciplinas como: Ética Profissional, Perícia Contábil, Monografia e Trabalhos de Conclusão de Curso, entre outras.

O que se pode concluir pelo exposto é que o profissional contábil é um elemento de extrema importância no cenário global e o aprendizado contínuo e de qualidade é um dos requisitos essenciais para o sucesso desse profissional.

\subsection{A FEA-USP}

A Faculdade de Economia, Administração e Contabilidade da Universidade de São Paulo (FEA-USP) foi criada em janeiro de 1946, logo após o término da Segunda Guerra Mundial e simultaneamente com a redemocratização do Brasil ${ }^{4}$.

A nova instituição surgiu doze anos depois da constituição da Universidade de São Paulo, com o nome de Faculdade de Ciências Econômicas e Administrativas (FCEA), numa época em que a economia brasileira acelerava seu processo de industrialização e ampliava significativamente o setor de serviços, deixando de ser predominantemente agrária e exportadora.

As transformações da economia fizeram crescer a demanda por profissionais especializados em economia, administração e contabilidade, particularmente em São Paulo, principal centro econômico do Brasil.

\footnotetext{
${ }^{4}$ Informações disponíveis em www.fea.usp.br. Acesso em 20/12/2005.
} 
No mesmo ano da criação da FEA-USP, o Centro Acadêmico Visconde de Cairu tornou-se o órgão de representação dos alunos da nova instituição, participando ativamente das lutas do movimento estudantil pelo aprimoramento do ensino, em defesa da democracia e dos direitos humanos, e da maior representação dos alunos nos órgãos colegiados da Universidade. Nos anos 50 foi criada a Associação dos Antigos Alunos, depois Associação de Ex-Alunos e atualmente Associação dos Diplomados da FEA. Desde as primeiras turmas de formandos, muitos ex-alunos passaram a exercer, por mérito, as tarefas de ensino, pesquisa e administração da FEA.

Nas décadas de 50 e 60, o sistema educacional brasileiro começou a dar mais ênfase às matérias exigidas pelo novo estágio da economia, entre elas, matemática, administração financeira, contabilidade de custos e métodos quantitativos. A FEA adaptou seu currículo às exigências do mercado de trabalho, interessado na maior qualificação técnica de economistas, contabilistas, atuários e administradores de empresas.

Em 1992, a FEA decidiu implantar em Ribeirão Preto uma unidade capaz de gerar e difundir conhecimentos nas áreas de Economia, Administração e Contabilidade ${ }^{5}$, atendendo a antigas demandas da sociedade. Usufruindo as tradições e competências acumuladas pela FEA em São Paulo, que ao longo de cinco décadas de trabalho é reconhecida nacional e internacionalmente, a FEA-RP deu início a sua trajetória.

Localizada em uma área que ocupa uma das mais ricas fazendas de café do século XIX, a FEA-RP está instalada em prédio histórico, atualmente tombado como patrimônio cultural (antiga Biblioteca Central), onde procura, com intensa atuação de seus docentes, alunos e funcionários, manter-se na vanguarda do ensino, da pesquisa e extensão em Economia, Administração e Contabilidade.

\footnotetext{
${ }^{5}$ Informações disponíveis em www.fearp.usp.br. Acesso em 20/12/2005.
} 
Hoje, a FEA-RP é formada por professores e funcionários que buscam atingir um importante objetivo: proporcionar aos seus estudantes uma sólida formação, que venha a refletir-se num futuro próximo, em uma boa condição de desenvolvimento e aperfeiçoamento das atividades econômicas, sociais e culturais de toda a região.

São oferecidas 45 vagas em cada um dos cursos de graduação em Administração, Contabilidade e Economia. Esses cursos, ministrados no período noturno, com duração mínima de quatro anos, objetivam garantir aos alunos uma formação técnico-profissional, aliada a uma formação humanística, capaz de assegurar não só o eficiente desempenho profissional, mas também credenciá-los a enfrentar os desafios que a sociedade moderna, dinâmica e mutante, apresenta a cada momento. Com os mesmos propósitos são ministrados os cursos diurnos de graduação em Administração e Economia Empresarial e Controladoria, que oferecem 60 e 70 vagas, respectivamente.

O curso de Administração proporciona aos seus alunos capacitação nos diversos ramos do conhecimento ligados à área: organização empresarial, finanças, marketing, recursos humanos, operações, métodos quantitativos, informática, política de negócios e economia de empresas. $\mathrm{O}$ ensino tem sido enriquecido por pesquisas realizadas pelos docentes, na própria faculdade, e por defesas nacionais e internacionais de artigos, conjugando esforços de alunos em iniciação científica.

O curso de Economia destaca-se por estar baseado numa proposta curricular atual, propiciando ao futuro profissional economista uma formação compatível com as demandas do presente e do que se pode vislumbrar do futuro. Tem-se uma série de disciplinas oferecidas, das quais várias são eletivas, cabendo ao aluno promover uma combinação que melhor satisfaça suas aspirações e pretensões de qualificação acadêmica e profissional. Entre as ênfases disponíveis encontram-se, por exemplo, disciplinas nas áreas de Comércio Internacional e Finanças. 
O curso de Contabilidade oferece aos alunos um elenco de disciplinas obrigatórias e optativas, como destacado a seguir:

- Obrigatórias - disciplinas de formação humanística e social, disciplinas básicas nas áreas de Administração Geral, Economia e Informática e disciplinas de formação específica nas áreas de Contabilidade Geral, Contabilidade e Análise de Custos, Controladoria e Gestão Financeira, Auditoria e Sistemas de Informações Contábeis;

- Optativas - abrangem os domínios de conhecimento mais relevantes e atuais na área, possibilitando ao aluno direcionar a sua formação para áreas de exercício profissional pelas quais ele possua particular interesse. Os alunos podem atuar nos laboratórios de pesquisa, realizando projetos de iniciação científica, que fornecem a base para a elaboração do trabalho de formatura exigido para a conclusão do curso.

Já o curso de Economia Empresarial e Controladoria objetiva fornecer conhecimentos práticos e teóricos multidisciplinares, diferenciados dos atuais cursos de Ciências Econômicas e Ciências Contábeis existentes. Promove a formação de Bacharéis em Economia Empresarial e Controladoria, com as competências e habilidades contemporâneas demandadas pelo ramo de atuação acadêmica e profissional globalizados. Essencialmente, o curso é desenvolvido em duas etapas, sendo a primeira, composta dos três anos iniciais, voltada para a sólida formação multidisciplinar, e a segunda, que compreende o quarto ano, voltada para a especialização do aluno em uma das áreas de concentração propostas.

A FEA-RP também oferece cursos de Pós-Graduação Stricto-Sensu (Mestrado) em Administração de Organizações, Economia Aplicada e Controladoria e Contabilidade.

Dentro das atividades de pesquisa encontram-se vários grupos, focados em diversas linhas, tais como, Balanço Social e Contabilidade Ambiental, Contabilidade Internacional, Ensino da Contabilidade, Finanças Corporativas, Controladoria e Custos, Tecnologia e Ambiente Educacional etc. 
No que diz respeito à extensão, a FEA-RP conta com a FUNDACE - Fundação para Pesquisa e Desenvolvimento da Administração, Contabilidade e Economia - que oferece cursos em nível de especialização ( $M B A$ ’’s).

Dessa forma, a FEA-RP busca transformar-se em um centro de excelência no estudo da Administração, Contabilidade e Economia, procurando dar, ao mesmo tempo, uma importante contribuição para aprimorar e intensificar a ligação Empresa - Universidade Comunidade.

\subsection{Características da educação contábil}

De acordo com dados do Sistema de Informações da Educação Superior (SiedSup) do Ministério da Educação (MEC) e Instituto Nacional de Estudos e Pesquisas Educacionais (INEP) no ano de 2005 existiam 877 cursos de graduação/habilitações em Ciências Contábeis no Brasil e um curso de graduação/habilitação em Contabilidade e Custos, na cidade de São Paulo. Numa última pesquisa realizada no site do INEP, em junho de 2006 , foram localizados 927 cursos/habilitações em Ciências Contábeis e a permanência do único curso em Contabilidade e Custos. ${ }^{6}$

O curso de Ciências Contábeis está em sétimo lugar entre os dez maiores cursos em número de matrículas e concluintes. Segundo o censo do MEC/INEP existiam, em 2004, cerca de 162.150 alunos matriculados nos cursos de graduação em Ciências Contábeis, sendo que, neste mesmo ano, se formaram 24.213 novos profissionais. ${ }^{7}$

\footnotetext{
${ }^{6}$ Disponível em: http://www.educacaosuperior.inep.gov.br/funcional/lista_cursos.asp. Acesso em 23/01/2006 e 13/06/2006.

${ }^{7}$ Disponível em: http://www.ensinosuperior.inep.gov.br/. Acesso em 23/01/2006 e 14/06/2006. No momento dessa pesquisa o Censo 2005 ainda não havia sido divulgado.
} 
Em relação aos cursos de pós-graduação relacionados à Contabilidade, conforme informações da Coordenação de Aperfeiçoamento de Pessoal de Nível Superior - CAPES em 2004 a situação dos cursos e titulados no ano era como demonstra a tabela 1 a seguir ${ }^{8}$ :

Tabela 1 - Cursos de pós-graduação e quantidade de titulados em 2004

\begin{tabular}{lcccc}
\hline PROGRAMA & INSTITUIÇÃO & UF & TIPO DE CURSO & TITULADOS \\
\hline Ciências Contábeis & UNB & DF & Mestrado & 21 \\
\hline Ciências Contábeis & UFRJ & RJ & Mestrado & 15 \\
\hline Ciências Contábeis & UNISINOS & RS & Mestrado & 20 \\
\hline $\begin{array}{l}\text { Ciências Contábeis e } \\
\text { Atuariais }\end{array}$ & PUC/SP & SP & Mestrado & 26 \\
\hline $\begin{array}{l}\text { Controladoria e } \\
\text { Contabilidade Estratégica }\end{array}$ & UniFECAP & SP & Mestrado & 23 \\
\hline $\begin{array}{l}\text { Controladoria e } \\
\text { Contabilidade }\end{array}$ & USP & SP & Mestrado & 46 \\
\hline $\begin{array}{l}\text { Controladoria e } \\
\text { Contabilidade }\end{array}$ & USP & SP & Doutorado & 7 \\
\hline Contabilidade & UFSC & SC & Mestrado & 0 \\
\hline $\begin{array}{l}\text { Ciências Contábeis } \\
\text { Controladoria }\end{array}$ & FUCAPE & ES & $\begin{array}{c}\text { Mestrado } \\
\text { Profissionalizante }\end{array}$ & 23 \\
\hline Fonte: CAPES & UFC & CE & $\begin{array}{c}\text { Mestrado } \\
\text { Profissionalizante }\end{array}$ & 0 \\
\hline
\end{tabular}

Uma pesquisa realizada em junho de 2006, mostra que a situação atual de cursos de pós-graduação ligados à área contábil é conforme demonstra o quadro 7 a seguir?

8 Disponível em: http://ged.capes.gov.br/AgDw/silverstream/pages/frPesquisaColeta.html. Acesso em 14/06/2006. No momento dessa pesquisa a CAPES ainda não tinha divulgado os números do ano seguinte (2005).

9 Disponível em: http://www.capes.gov.br/capes/portal/conteudo/10/ProgramasReconhecidos.htm. Acesso em 14/06/2006. 


\begin{tabular}{|l|c||c|c||}
\hline \hline PROGRAMA & INSTITUIÇÃO & UF & TIPO DE CURSO \\
\hline Ciências Contábeis & UNB & DF & Mestrado \\
\hline \hline Ciências Contábeis & FUCAPE & ES & $\begin{array}{c}\text { Mestrado } \\
\text { Profissionalizante }\end{array}$ \\
\hline Ciências Contábeis & UFRJ & RJ & Mestrado \\
\hline \hline Ciências Contábeis & UERJ & RJ & Mestrado \\
\hline Ciências Contábeis & UNISINOS & RS & Mestrado \\
\hline \hline Ciências Contábeis & FURB & SC & Mestrado \\
\hline Ciências Contábeis e Atuariais & PUC/SP & SP & Mestrado \\
\hline \hline Contabilidade & UFPR & PR & Mestrado \\
\hline \hline Contabilidade & UFSC & SC & Mestrado \\
\hline \hline Controladoria & UFC & CE & $\begin{array}{c}\text { Mestrado } \\
\text { Profissionalizante }\end{array}$ \\
\hline \hline Controladoria e Contabilidade & USP & SP & Mestrado e Doutorado \\
\hline \hline Controladoria e Contabilidade & USP/RP & SP & Mestrado \\
\hline Controladoria e Contabilidade Estratégica & UniFECAP & SP & Mestrado \\
\hline \hline
\end{tabular}

Quadro 7 - Mestrados/Doutorado reconhecidos - grande área: Ciências Sociais Aplicadas Fonte: CAPES.

No que diz respeito ao conteúdo sugerido para os cursos de Contabilidade, presente nas diretrizes curriculares observa-se que este deixa de ser uma orientação sobre disciplinas e cargas didáticas, passando a ser referências de dosagens de assuntos para o programa. O MEC tem apresentado a idéia do currículo pleno, dando liberdade para as instituições de ensino de Ciências Contábeis na definição do perfil do profissional a ser formado e de que forma será feita.

Entretanto, tal liberdade, juntamente com o desejo de se ofertar um curso adequado, tem provocado dúvidas e indagações entre os responsáveis pela definição do referido curso. Nem sempre as disciplinas são apresentadas de maneira coordenada, lógica e consistente, o que pode causar ensinamentos repetitivos e sem sequiência adequada. Espera-se que o aluno, ao final do curso, reúna as competências e conteúdos necessários para desenvolver a sua profissão.

Em uma sociedade de conhecimento, o sistema de ensino em Contabilidade passa a exigir um modelo interativo, no qual educadores e alunos se coloquem como participantes do processo ensino-aprendizagem de forma mais ampla na produção e disseminação do 
conhecimento contábil. Portanto, o ensino em Contabilidade deveria proporcionar novos esquemas de ação lógica e crítica, criando novas perspectivas sobre o mundo e novas estratégias e habilidades de pensamento nos campos pessoal, cultural e profissional do aluno.

De acordo com o artigo $5^{\circ}$ da Resolução CNE/CES n ${ }^{\circ}$ 10/2004, pressupõe-se uma informação mais abrangente nos conteúdos obrigatórios para formação básica, profissional e teórico-prática no curso de Ciências Contábeis. Tais conteúdos são:

I - conteúdos de Formação Básica: estudos relacionados com outras áreas do conhecimento, sobretudo Administração, Economia, Direito, Métodos Quantitativos, Matemática e Estatística;

II - conteúdos de Formação Profissional: estudos específicos atinentes às Teorias da Contabilidade, incluindo as noções das atividades atuariais e de quantificações de informações financeiras, patrimoniais, governamentais e não-governamentais, de auditorias, perícias, arbitragens e controladoria, com suas aplicações peculiares ao setor público e privado;

III - conteúdos de Formação Teórico-Prática: Estágio Curricular Supervisionado, Atividades Complementares, Estudos Independentes, Conteúdos Optativos, Prática em Laboratório de Informática utilizando softwares atualizados para Contabilidade.

Na configuração do Currículo Pleno para o curso de Ciências Contábeis, as instituições de ensino têm a liberdade para considerar as peculiaridades locais e regionais em função da opção de ênfase escolhida pelo curso que for adequada ao perfil desejado do formando, obedecendo, entretanto, o limite de $50 \%$ da carga horária total para os conteúdos de formação básica e profissional e $50 \%$ para os conteúdos das ênfases curriculares. Dessa forma o curso de Contabilidade passa a ter um caráter especialista.

De acordo com Cornachione Júnior (2004, p. 188-190) apesar dos aspectos formais ou qualquer característica de outros documentos, há um documento elaborado pela Comissão de 
Especialistas em Educação Contábil a pedido do Ministério da Educação, em 1999, contendo uma proposta curricular detalhada para os programas de graduação em Ciências Contábeis no Brasil. Esse documento foi submetido ao Ministério da Educação como forma de contribuição à elaboração do Parecer MEC/CNE/CES 146/2002. O quadro seguinte reúne esses conteúdos:

\begin{tabular}{|c|c|}
\hline CONTEÚDOS OBRIGATÓRIOS & CURRÍCULO DE CIÊNCIAS CONTÁBEIS \\
\hline Administração & $\begin{array}{c}\text { Teoria Geral da Administração } \\
\text { Estratégia Empresarial } \\
\text { Comportamento Organizacional }\end{array}$ \\
\hline Economia & $\begin{array}{c}\text { Teoria da Firma } \\
\text { Cenários Econômicos e Economia Internacional } \\
\text { Economia de Empresas }\end{array}$ \\
\hline Direito & $\begin{array}{c}\text { Legislação Social e Trabalhista } \\
\text { Direito Tributário } \\
\text { Direito Comercial e Societário } \\
\end{array}$ \\
\hline Métodos Quantitativos & $\begin{array}{c}\text { Medidas de Tendência Central e de Dispersão } \\
\text { Regressão e Correlação } \\
\text { Análise de Série Temporal } \\
\text { Cálculo Integral e Diferenciação } \\
\end{array}$ \\
\hline Teoria da Contabilidade & $\begin{array}{c}\text { História do Pensamento Contábil } \\
\text { Ativo e Passivo e sua Mensuração } \\
\text { Receitas, Despesas, Perdas e Ganhos e suas Mensurações. } \\
\text { Teorias do Patrimônio Líquido } \\
\text { Princípios Fundamentais de Contabilidade e } \\
\text { Harmonização Contábil } \\
\end{array}$ \\
\hline Contabilidade Financeira & $\begin{array}{c}\text { Princípios, Normas e Procedimentos; } \\
\text { Elaboração e Evidenciação das Demonstrações Contábeis }\end{array}$ \\
\hline Contabilidade Tributária & $\begin{array}{c}\text { Contabilidade de Tributos Federais, Estaduais e Municipais. } \\
\text { Planejamento Tributário } \\
\end{array}$ \\
\hline Contabilidade Gerencial & $\begin{array}{c}\text { Métodos de Custeio } \\
\text { Sistemas de Acumulação de Custos } \\
\text { Análise de Custos } \\
\text { Descentralização (Preço de Transferência e Centros de Resultados) }\end{array}$ \\
\hline Auditoria & $\begin{array}{c}\text { Controles Internos } \\
\text { Princípios, Normas e Procedimentos de Auditoria. } \\
\text { Planejamento de Auditoria } \\
\text { Papéis de Trabalho } \\
\end{array}$ \\
\hline Controladoria & $\begin{array}{c}\text { Sistemas de Informações } \\
\text { Processo de Planejamento, Execução e Controle. } \\
\text { Avaliação de Desempenho } \\
\text { Responsabilidade de Prestação de Contas (Accountability) } \\
\end{array}$ \\
\hline
\end{tabular}

Quadro 8 - Conteúdos obrigatórios propostos para os cursos de Ciências Contábeis Fonte: CORNACHIONE JÚNIOR, 2004, p. 189.

O documento apresenta, também, uma coleção de assuntos envolvendo habilidades e competências complementares na construção do currículo de Ciências Contábeis, por meio de cursos ou disciplinas optativas, conforme demonstra o quadro 9. 


\begin{tabular}{|c|c|}
\hline CONTEÚDO & TÓPICOS SUGERIDOS \\
\hline Administração & $\begin{array}{l}\text { Teoria da Comunicação (semiótica) } \\
\text { Sociologia das Organizações } \\
\text { Contabilidade de Recursos Humanos } \\
\text { Jogos de Empresas }\end{array}$ \\
\hline Economia & Análise de Cenários Econômicos e Financeiros \\
\hline Direito & $\begin{array}{c}\text { Procedimentos para Abertura, Manutenção e Encerramento de Empresas; } \\
\text { Aquisições, Fusões, Incorporações, Cisões, Privatizações etc. }\end{array}$ \\
\hline Métodos Quantitativos & $\begin{array}{c}\text { Análise de Riscos e de Carteiras de Investimento } \\
\text { Informação Contábil para Decisões de Crédito }\end{array}$ \\
\hline Teoria da Contabilidade & $\begin{array}{c}\text { Contabilidade Social } \\
\text { Contabilidade Ambiental } \\
\text { Demonstração do Valor Adicionado } \\
\text { Balanço Social } \\
\text { Contabilidade, Orçamento e Auditoria Governamental }\end{array}$ \\
\hline Contabilidade Financeira & $\begin{array}{c}\text { Contabilidade Internacional } \\
\text { Contabilidade Inflacionária (Juros e Câmbio) }\end{array}$ \\
\hline Contabilidade Tributária & "Contabilidade Financeira (Aspectos Legais) \\
\hline Contabilidade Gerencial & $\begin{array}{c}\text { Leasing, Factoring, Hedging, Derivativos, Securitização } \\
\text { Mercado de Capitais (Estrutura \& Análise) } \\
\text { Gestão Estratégica de Custos \& Logística } \\
\end{array}$ \\
\hline Auditoria & $\begin{array}{l}\text { Auditoria Interna } \\
\text { Perícia }\end{array}$ \\
\hline Controladoria & $\begin{array}{c}\text { Sistema de Informação } \\
\text { Teoria e Análise de Sistemas } \\
\text { Planejamento Estratégico, Tático, Operacional e Orçamento } \\
\text { Gestão de Tecnologias e Processos Avançados de Produção } \\
\text { Avaliação de Empresas } \\
\end{array}$ \\
\hline Conteúdo Extra & $\begin{array}{l}\text { Trabalho de Conclusão de Curso } \\
\text { Estágio Supervisionado }\end{array}$ \\
\hline
\end{tabular}

Quadro 9 - Conteúdos complementares propostos para os cursos de Ciências Contábeis Fonte: CORNACHIONE JÚNIOR, 2004, p. 190.

Essa proposta mostra-se ligada às necessidades mais atuais da área de Contabilidade.

Com isso, é possível observar que há, no Brasil, uma preocupação por parte do governo e dos conselhos profissionais (CFC - Conselho Federal de Contabilidade e CRCs - Conselhos Regionais de Contabilidade) no que diz respeito a estrutura educacional em Contabilidade, desde o estabelecimento de metas culturais e profissionais, passando por sugestões de assuntos obrigatórios e optativos, que fundamentem as discussões tidas como essenciais para fomentar a educação do contador.

Pela breve descrição do elenco de disciplinas obrigatórias e optativas da grade curricular da FEA-RP, percebe-se o interesse da instituição em estar mais próxima dessas 
características e atender, com isso, as diversas exigências para a formação do profissional contábil.

\subsection{Competências e habilidades no ensino de Contabilidade}

Competências e habilidades são duas palavras muito importantes no contexto atual, visto que a própria Lei de Diretrizes e Bases da Educação (LDB) e regulamentações complementares trazem, por exemplo, uma definição de competência como sendo “capacidade de articular, mobilizar e colocar em ação valores, conhecimentos e habilidades necessárias para o desempenho eficiente de atividades requeridas pela natureza do trabalho" (Resolução CNE/CEB, nº 04/99, art.6).

As competências técnicas são conhecimentos que permitem a identificação mais direta com uma profissão e podem ser adquiridas, em parte no sistema educativo e na formação profissional e, em parte, na empresa. Combinando as competências transmitidas pelas instituições formais e as habilidades adquiridas por sua prática profissional e por suas iniciativas pessoais, em matéria de formação, o indivíduo torna-se agente e principal construtor da sua qualificação.

Segundo Iudícibus \& Franco (1983), há necessidade de se preparar profissionais, não apenas com o domínio das mais avançadas técnicas disponíveis, mas dotados de habilidades e do discernimento necessário para além do "como fazer", perseguirem "o que fazer". Dominar a técnica não é suficiente. O mais importante é estar preparado para perceber quando a técnica precisa evoluir.

Para que um aluno, futuro profissional, saia da universidade com essa ampla visão, Nossa (1999) diz que é necessário que se tenha uma estrutura adequada funcionando, um currículo compatível implantado e, principalmente, um corpo docente capaz de contribuir com 
essa formação. É preciso que o professor de Contabilidade tenha uma percepção clara da sociedade, que se encontra em rápida evolução. Deve compreender a realidade em que vive, integrando diariamente os diversos fenômenos sociais, políticos, econômicos e jurídicos. Em outras palavras, deve ter conhecimentos técnicos da Contabilidade e de áreas afins, de metodologia de ensino, de cultura geral e aptidões sociais.

Cabe ao professor mediar o processo de ensino-aprendizagem de forma competente, fazendo um papel muito mais de orientador do que de transmissor do conhecimento. Dentre as competências, deve ser destacada a maneira pela qual o professor motiva os alunos para a prática do conhecimento. A seriedade e a dedicação são habilidades que devem ser desenvolvidas por ele na execução dos programas das disciplinas sob sua responsabilidade e são condições imprescindíveis para o funcionamento de uma valiosa ferramenta que é o currículo.

No caso específico do papel do professor na formação profissional do aluno, a competência, segundo Giorgi (2001) adquire uma abrangência que inclui: conhecimentos teóricos, pedagogia e experiência profissional, o que é demonstrado no quadro 10, apresentado a seguir. 


\begin{tabular}{|c|c|c|}
\hline $\begin{array}{l}\text { NÍVEL } \\
\text { GLOBAL }\end{array}$ & $\begin{array}{l}\text { ÁREAS } \\
\text { PRINCIPAIS }\end{array}$ & SUB-ÁREAS \\
\hline \multirow{5}{*}{$\begin{array}{l}\text { Competência } \\
\text { global do } \\
\text { professor }\end{array}$} & $\begin{array}{l}\text { Base de } \\
\text { conhecimento } \\
\text { explícito }\end{array}$ & $\begin{array}{l}1 \text { - Recursos Curriculares; } \\
2 \text { - Recursos Pedagógicos; } \\
3 \text { - Experiência Profissional; }\end{array}$ \\
\hline & $\begin{array}{l}\text { Planejamento e } \\
\text { preparação }\end{array}$ & $\begin{array}{l}\text { - Conhecimentos claros a respeito de alunos, contexto e } \\
\text { recursos; } \\
5 \text { - Média adequada de atividades e recursos para alunos; }\end{array}$ \\
\hline & Ensino interativo & $\begin{array}{l}6 \text { - Assistência inteligente e eficiente ao aprendizado do } \\
\text { aluno, à organização e à pesquisa; } \\
7 \text { - Avaliação e monitoramento efetivo do aprendizado e } \\
\text { progresso do aprendizado do aluno; } \\
8 \text { - Adequado relacionamento para influenciar alunos, seu } \\
\text { comportamento, motivação e bem-estar; } \\
9 \text { - Avaliação e monitoramento efetivos do comportamento, } \\
\text { motivação e bem-estar do aluno; }\end{array}$ \\
\hline & $\begin{array}{l}\text { Modelo } \\
\text { profissional } \\
\text { abrangente } \\
\end{array}$ & $\begin{array}{l}10 \text { - Cumprir a tarefa de construir um modelo profissional } \\
\text { abrangente, através da colaboração efetiva e vários outros; }\end{array}$ \\
\hline & $\begin{array}{l}\text { Auto- } \\
\text { desenvolvimento } \\
\text { profissional }\end{array}$ & $\begin{array}{l}11 \text { - Desenvolvimento de conhecimento básico específico } \\
\text { da matéria, pedagogia e profissional; } \\
12 \text { - Melhoria da capacidade profissional, através de estudo, } \\
\text { reflexão e mudança. }\end{array}$ \\
\hline
\end{tabular}

Quadro 10 - Uma análise dos níveis de competência do professor

Fonte: Adaptado de GIORGI, 2001.

Quanto à expectativa dos agentes em relação ao perfil do formando em Ciências Contábeis, o curso deverá gerar oportunidade para o graduando ter uma sólida formação gerencial e humanística com a capacidade de análise e articulação de conceitos e argumentos de interpretação e valorização dos fenômenos contábeis e sociais, além da qualificação para a vida, o trabalho e o desenvolvimento da cidadania.

O formando em Contabilidade deve ter conhecimento técnico satisfatório e habilidade para aplicá-lo de forma analítica e prática, ter interdisciplinaridade na resolução de problemas, diferenciar problemas relevantes de não relevantes, ter habilidade para integrar diversas áreas de conhecimento, ter capacidade de comunicação efetiva com usuários e agir de forma ética.

Espera-se que o profissional contábil egresso tenha a responsabilidade social e a atuação técnica e instrumental articulada com outros ramos do saber, evidenciando o domínio de competências e habilidades inter e multidisciplinares para a consecução da sua atuação profissional. 
Conforme Pereira e Leite Filho (2002, p. 30) o profissional contábil esperado pela sociedade é aquele que agrega valor à organização, com uma cultura acima da média, atualizada e consciente da sua responsabilidade social, que age com ética e trabalha com competência e dignidade para proporcionar ao usuário da informação, e a toda a sociedade, a confiabilidade esperada.

Além disso, as competências e habilidades preconizadas pelas diretrizes curriculares para o curso superior de Ciências Contábeis constam na Resolução CNE/CES no 6 de 31 de março de 2004 e Resolução CNE/CES no 10 de 16 de dezembro de 2004 do MEC, conforme exposto a seguir:

Art. $4^{\circ}$. O curso de graduação em Ciências Contábeis deve possibilitar a formação profissional que revele, pelo menos, as seguintes competências e habilidades:

I - utilizar adequadamente a terminologia e a linguagem das Ciências Contábeis e Atuariais;

II - demonstrar visão sistêmica e interdisciplinar da atividade contábil;

III - elaborar pareceres e relatórios que contribuam para o desempenho eficiente e eficaz de seus usuários, quaisquer que sejam os modelos organizacionais;

IV - aplicar adequadamente a legislação inerente às funções contábeis;

V - desenvolver, com motivação e através de permanente articulação, a liderança entre equipes multidisciplinares para a captação de insumos necessários aos controles técnicos, à geração e disseminação de informações contábeis, com reconhecido nível de precisão;

VI - exercer suas funções com o expressivo domínio das funções contábeis e atuariais que viabilizem aos agentes econômicos e aos administradores de qualquer segmento produtivo ou institucional o pleno cumprimento da sua responsabilidade quanto ao gerenciamento, aos controles e à prestação de contas da sua gestão perante a sociedade, 
gerando, também, informações para a tomada de decisão, organização de atitudes e construção de valores orientados para a cidadania;

VII - desenvolver, analisar e implantar sistemas de informação contábil e de controle gerencial;

VIII - exercer com ética e proficiência as atribuições e prerrogativas que lhe são prescritas através da legislação específica, revelando domínios adequados aos diferentes modelos organizacionais.

Kraemer (2005, p. 73) afirma que isso requer uma nova visão do papel do professor, ratificando, inclusive, a importância do planejamento de ensino, da utilização de metodologias diversificadas, da revisão constante dos critérios de avaliação e da correta utilização dos recursos da tecnologia.

Os contabilistas têm que atuar num ambiente que exige informações úteis, completas e corretas e em curto espaço de tempo. Devem ter competência para empreender ações, analisando criticamente as organizações, antecipando e promovendo suas transformações, e compreensão da necessidade do contínuo aperfeiçoamento profissional.

Com todas essas exigências deve-se destacar a importância da qualidade na formação do profissional contábil para capacitá-lo adequadamente.

\subsection{A qualidade do ensino de Contabilidade}

Da criação do curso superior de Contabilidade até hoje, nota-se um enorme crescimento na quantidade de autorizações do MEC e um ponto crítico em todo esse processo: a qualidade do ensino. 
A educação sempre foi alvo de preocupações em todas as áreas de conhecimento e a área contábil, há algum tempo, vem demonstrando preocupações com a qualidade do ensino oferecido bem como com a formação de seus futuros profissionais.

No Brasil nota-se a necessidade de grandes mudanças no ensino superior, pois o nível dos profissionais que chegam ao mercado de trabalho nem sempre condiz com a expectativa. A globalização e os avanços tecnológicos têm forçado as organizações a buscarem profissionais mais contextualizados e multidisciplinares. Nos cursos de Ciências Contábeis verifica-se que é preciso uma adequação do estudante à realidade econômica e social.

A melhoria dos cursos de Ciências Contábeis se dá desde o início pelo compromisso e uma maior dedicação por parte dos professores, como também, uma participação mais adequada das instituições de ensino superior nos investimentos em recursos humanos e, principalmente, na capacitação didático-pedagógica dos professores de Contabilidade.

Laffin (2001) relata que o ensino tem a intencionalidade de ajudar o aluno a entender as diferentes relações de saberes dos sujeitos históricos. Nessa perspectiva, infere que a intencionalidade do professor de Contabilidade é a de ensinar e de aprender e, assim, considera como atributos da identidade profissional desse professor:

- O domínio dos conhecimentos específicos de sua área de atuação, apropriados na sua formação inicial e continuada, para relativizar os conhecimentos produzidos pela sociedade, tornando-se sujeito capaz de transformar a realidade social;

- O trabalho docente que enfatiza a articulação dos conteúdos contábeis com as demais áreas do saber, superando a concepção meramente do saber fazer;

- A profissionalização que mantém implicações diretas com a formação do profissional da Contabilidade com um perfil crítico ao novo contexto;

- A inserção nas forças em favor da valorização de uma política salarial, das condições de trabalho e com o vínculo na carreira de formação inicial e continuada; 
- A compreensão do ensino - pesquisa - extensão como indissociáveis do seu trabalho.

Para o autor, tais atributos do professor de Contabilidade ajudam a refletir sobre a formação do professor que ensina Contabilidade e a destacar como primordial a necessidade do estabelecimento de um diálogo entre a sua formação inicial e o caráter essencial da docência por meio da reflexão-ação e da reflexão de sua ação docente.

Kraemer (2005, p.71) expõe que o professor de nível superior da formação profissional tem a responsabilidade de formar pessoas com competências e habilidades para dar a sua contribuição, atuando como docente, como profissional, ou pesquisador, dentro de padrões técnicos nacionais e internacionais.

De acordo com a mesma autora "o grande desafio da educação contábil é adequar seus aprendizes à demanda da realidade econômica com responsabilidade e competência". A autora afirma que "a linha educacional que tem sido adotada impossibilita o aluno a criar e o torna reprodutor de idéias entendidas como verdades absolutas". Cabe ao professor formar profissionais críticos, motivados, criativos, com raciocínio contábil e interesse pela pesquisa.

Sozinho, nenhum professor poderá ter tanto poder, mas, através do trabalho interdisciplinar, os esforços de toda uma equipe de profissionais altamente competentes poderão ser somados para atingir esse objetivo. É necessário que o professor de Contabilidade esteja inserido num projeto pedagógico participativo, no qual seja possível reconstruir sua prática, seus saberes e sua competência.

A universidade deve expandir sua intervenção para além dos aspectos técnicos a fim de formar profissionais capacitados a agregar valor no mercado de trabalho. O ensino deve propiciar o aprendizado da Contabilidade, a nível teórico e prático e preparar o profissional para enfrentar a realidade por meio do desenvolvimento de aptidões humanas, tais como criatividade, flexibilidade, capacidade de relacionar-se, trabalhar em equipe, dentre outras. 
Uma etapa importante da ligação entre educação superior e exercício profissional, segundo Cornachione Júnior (2004, p. 191-192) é cumprida pela avaliação de suficiência técnica e profissional. Esse tipo de avaliação busca dar maior segurança à própria sociedade por meio da averiguação pontual (prova ao término do curso superior), amostral (cobertura parcial de assuntos com ponderações discutíveis) e técnica (aspectos comportamentais, humanos e culturais não compõem, em sua essência, essa avaliação). A avaliação de suficiência técnica e profissional é adotada pela sociedade tanto do Brasil (CFC - Conselho Federal de Contabilidade) como dos Estados Unidos (AICPA - The American Institute of Certified Public Accountants).

Cornachione Júnior (2004, p. 193) relata, também, que devido às próprias características dessa área de conhecimento, em especial os detalhes de atuação profissional, é arriscado considerar a formação do programa de graduação suficiente para amparar o exercício profissional pela vida toda. Sendo assim, os programas de educação continuada, como cursos sobre assuntos pontuais e correntes, são muito importantes para os profissionais da Contabilidade bem como para profissionais de qualquer outra área.

Conhecer as metodologias didáticas para utilizá-las adequadamente no processo de ensino também pode ajudar a melhorar a qualidade dos cursos.

\subsection{Metodologias didáticas aplicadas ao ensino de Contabilidade}

A metodologia tradicional de ensino objetiva a transferência de conhecimentos e avaliação do conteúdo aprendido pelos alunos. Sob a ótica das modernas metodologias de ensino, o aluno tem papel ativo em seu processo de aprendizagem. A participação efetiva por meio de comentários, críticas, discussões e análises é amplamente desejável no intuito de reforçar o raciocínio e o espírito crítico, contribuindo para uma formação mais completa. 
Marion (2001, p.33-36) classifica as metodologias de ensino de contabilidade em dois tópicos: o aluno como agente passivo no processo de aprendizagem, com predominância das técnicas tradicionais de ensino, e o aluno como agente ativo no processo de aprendizagem, que abriga as técnicas mais modernas ou inovadoras de ensino. De acordo com Marion a posição ativa no processo de aprendizagem por parte dos alunos faz com que os mesmos tornem-se pensadores críticos, desenvolvendo assim, a capacidade de auto-iniciativa e de descobrimento, levando a um aprendizado contínuo e ao crescimento profissional.

Romanowsky e Beuren (2002) estudaram os procedimentos metodológicos de ensino utilizados nos cursos de Ciências Contábeis e propuseram pontos norteadores para desenvolver uma metodologia com vistas a uma melhor formação do egresso, dentre eles:

- Os saberes dos alunos como ponto de partida para a construção dos conhecimentos;

- Interação professor-aluno-conhecimento, tendo a prática como referência;

- Trabalho em parceria entre professores e alunos, superando a situação de dependência para a de autonomia;

- A pesquisa como possibilidade de melhoria da aprendizagem dos alunos.

Diante dessas exposições, pode-se dizer que o aluno é a peça principal no processo de ensino-aprendizagem, pois é ele que deve conduzir o ensino indicando suas necessidades e possibilidades. As metodologias didáticas deveriam ser definidas de acordo com essas necessidades e possibilidades, visto que, como dito no início deste trabalho, no processo de ensino-aprendizagem o professor é a pessoa que pode determinar se seus alunos irão atingir os objetivos educacionais ou não. Conhecendo bem os seus alunos, o professor poderá identificar quais metodologias poderão ser aplicadas no processo. 


\subsection{Métodos didáticos}

Nérici (1981) afirma que "a metodologia didática tem por objetivo dirigir a aprendizagem do educando...". Já o método didático é conceituado pelo autor como "conjunto de procedimentos escolares lógica e psicologicamente estruturados, de que se vale o professor, para orientar a aprendizagem do educando...".

Conforme Marion (2001, p.127-128) o método utilizado pelo professor no processo de ensino-aprendizagem é de fundamental importância ao sucesso do aluno. Esse autor define método como "processo ou técnica de ensino que facilita a chegada ao conhecimento ou a demonstração de uma verdade".

Santos (2005) sintetiza o conceito afirmando que:

"Método de ensino é a maneira pela qual se estabelecem condições para a ocorrência de sinergia entre as partes do processo ensinoaprendizagem. O objetivo de um método de ensino é servir de suporte ao professor, de modo a criar condições favoráveis ao pleno desenvolvimento de uma aula, maximizando a assimilação de um assunto em discussão”.

De acordo com Nérici (1981) não há que se preocupar em diferenciar método de técnica, pois, ambos têm o mesmo objetivo: "levar o educando a seguir um esquema para eficiência da aprendizagem".

De uma forma bastante simplificada, considerando a finalidade e os limites do trabalho, apresenta-se a classificação dos métodos de ensino conforme Rocha (1997):

- Método prático ou "aprender fazendo" - por esse método, o aluno é levado a aprender pela realização de tarefas nas mesmas condições que são encontradas na realidade;

- Método conceitual ou "aprender a teoria" - nesse método a preocupação do professor reside em transmitir uma conceituação teórica, obrigando o aluno a utilizar tal teoria na resolução de problemas correlatos; 
- Método simulado ou "aprender na realidade imitada" - no método simulado, o professor cria um ambiente, o mais próximo da realidade, para que o aluno resolva os problemas propostos.

- Método comportamental ou "aprender por crescimento psicológico" - é um método mais complexo e de difícil avaliação quanto aos resultados alcançados, onde o professor orienta o aluno a assumir determinado papel em uma situação hipotética, mas possível de acontecer na vida profissional e avalia como ele se comporta diante de tal situação.

Sem a pretensão de esgotar o assunto, na seqüência são descritos alguns métodos que são e podem ser aplicados no ensino de Contabilidade (MARION, 2001: 128-132):

\section{a) Método expositivo}

O método de ensino mais conhecido e tradicional é o expositivo. Nele o conteúdo ministrado em aula quase sempre se baseia em um resumo de um assunto presente em um livro-texto, que é explicado para os alunos através de explanações nas quais a participação dos estudantes é nula ou quase nula.

Conforme Gil (1997, p. 76) o método expositivo é adequado para:

- Transmitir conhecimentos;

- Apresentar um assunto de forma organizada;

- Introduzir os alunos em determinado assunto;

- Despertar a atenção em relação ao assunto;

- Transmitir experiências e observações pessoais não disponíveis sob outras formas de comunicação;

- Sintetizar ou concluir uma unidade de ensino ou um curso. 


\section{b) Seminário}

Segundo Nérici (1981, p. 263) “o seminário é um procedimento didático que consiste em levar o educando a pesquisar a respeito de um tema a fim de apresentá-lo e discuti-lo cientificamente".

O mais importante no seminário não é a apresentação do tema, e sim, criar condições para a discussão, levar os acadêmicos ao debate, identificar e/ou reformular conceitos ou problemas e avaliar pesquisas.

\section{c) Dissertação ou resumo}

O método da dissertação ou resumo pode ser um complemento do seminário, ou pode ser aplicado individualmente. Consiste na execução de uma dissertação ou resumo após a visita a uma empresa, ou em complemento à projeção de fitas, ou para a leitura de livros.

\section{d) Exposições e visitas}

Esse método é muito interessante para o aprendizado e pode ser estruturado pelo professor de maneira que toda a turma seja beneficiada. Executa-se uma visita a uma indústria, um escritório, bolsa de valores etc. onde todos podem ouvir as explicações dos profissionais ou do professor, ao mesmo tempo em que têm contato com os papéis, conhecem o fluxo de documentos, forma de execução etc.

\section{e) Ciclo de debates}

É um método de fácil organização, pois o professor convida um profissional da área contábil ou áreas afins, para proferir palestras de no máximo 70 minutos e, em seguida, abrese para questionamentos. É bom, principalmente, para motivação profissional. Assuntos excessivamente técnicos e muito específicos não são aconselháveis para públicos maiores e heterogêneos. 


\section{f) Discussão com a classe}

É um método bastante tradicional, pois a sua aplicação sugere aos educandos a reflexão acerca de conhecimentos obtidos após uma leitura ou exposição, dando oportunidade aos alunos para formular princípios com suas próprias palavras, sugerindo a aplicação destes. Ao final da aula, sugere-se que o professor dê sua opinião sobre o assunto discutido, bem como a conclusão e fechamento da aula.

\section{g) Resolução de exercícios}

Esse método deve ser usado de modo complementar às aulas expositivas, servindo para fixar, compreender melhor e reforçar o conteúdo apresentado.

\section{h) Estudo de caso}

Conforme Rojas (1995) apud Marion (2001, p. 131) “o estudo de caso consiste em apresentar sucintamente a descrição de uma determinada situação real ou fictícia para sua discussão no grupo”. Pode ser de dois tipos: “o caso análise que objetiva o desenvolvimento da capacidade analítica do aluno, e o caso problema, que visa chegar a uma solução, a melhor possível, com os dados fornecidos pelo caso”.

\section{i) Aula prática}

Consiste em mostrar aos alunos o lado prático da disciplina. Para o curso de Contabilidade, o método deve ser aplicado em todas as disciplinas da área, direcionando-o como complemento às aulas teóricas - expositivas.

Uma das formas sugeridas é parte do curso ser desenvolvida no laboratório contábil, utilizando o processo eletrônico. Toda disciplina contábil poderá ser alvo do laboratório.

\section{j) Estudo dirigido}

Consiste na orientação aos alunos no estudo de determinado conteúdo. Porém, há de se observar a modalidade de percepção dos alunos que farão parte desse estudo, para que se faça 
uma programação voltada para aquele grupo, e o mesmo estudo não deverá ser estendido para outros grupos com modalidade de percepção diferente.

O uso deste método é recomendado para que cada aluno possa caminhar por si mesmo, conforme seu próprio ritmo.

\section{l) Jogo de empresas}

Permite aos alunos, em grupo, tomar decisões em empresas virtuais, negociando com outras empresas de outros grupos da sala de aula ou até mesmo de outras classes, períodos e cursos.

O objetivo deste método é desenvolver nos participantes de um curso a habilidade em tomar decisões baseadas em dados contábeis e de mercado, através da utilização de um jogo onde estes participantes representam a diretoria de empresas que competem em um mesmo mercado.

\section{m) Simulações}

As simulações são realizadas principalmente através de softwares educacionais que permitam diversas opções ao aluno, revisando constantemente suas decisões.

\subsection{Meios didáticos}

Meios didáticos são todos os recursos físicos e materiais empregados no processo de ensino-aprendizagem e que têm por finalidade tornar mais eficaz a transmissão de informações de uma pessoa para outra, direta ou indiretamente. Citam-se, por exemplo, os recursos audiovisuais e tecnológicos, tais como: a entrevista, o experimento em laboratório, a lousa, o vídeo cassete, o DVD, a televisão, as transparências, o projetor multimídia, o computador etc. 
De acordo com Belhot (1997, p. 26) "cada recurso é indicado para determinados casos e sob condições específicas. Consequentemente, não existe um recurso que seja superior aos demais, aplicável a qualquer finalidade e para qualquer aluno”.

Os meios didáticos mais utilizados são a lousa e o giz. Outra alternativa muito utilizada são as transparências. Alguns outros meios são ainda pouco usados, talvez por falta de informação, experiência ou mesmo vontade de mudar.

Assim como dito em relação aos métodos didáticos, sem a pretensão de esgotar o assunto, citam-se a seguir, alguns meios didáticos:

\section{a) Videoconferência}

É uma transmissão de conhecimentos de forma não presencial, uma teleconferência, ou seja, emprega recursos televisuais. Apresenta diversas vantagens quando utilizado, principalmente, na educação à distância.

Nesse sentido, o MEC instituiu a Portaria n 2.253 de 19 de outubro de 2001, que em seu artigo primeiro determina: "As instituições de ensino superior do sistema federal de ensino poderão introduzir (...) a oferta de disciplina que, em seu todo ou em parte, utilizem método não presencial...”.

\section{b) Vídeo cassete e DVD}

Esse recurso é mais utilizado para apresentar a opinião de autoridades em contabilidade sobre determinados temas. Deve-se atentar para o fato de organizar a sequência das apresentações, além do momento a ser utilizado conforme o tema que se pretende abordar, procurando, sempre que possível, associá-lo a realidade profissional.

O ideal é a existência de uma videoteca com acervo disponível tanto para os alunos quanto para os professores. 


\section{c) Retro projetor}

É um recurso muito utilizado pelos professores de Contabilidade, bem como de outras áreas, e apresenta como principal vantagem a de se dispensar a lousa, além de desenvolver a criatividade do docente e despertar a atenção do aluno. Deve-se atentar para alguns detalhes, tais como, a iluminação adequada do ambiente, pouco texto e visual agradável e de fácil compreensão, que são imprescindíveis para o sucesso do uso de tal ferramenta.

\section{d) Projetor multimídia}

Atualmente, um outro equipamento bastante utilizado, quando disponível nas instituições, é o projetor multimídia, o qual reproduz em telões, apresentações feitas em Power Point e outros softwares, diretamente das mídias computadorizadas. Este recurso obedece às mesmas condições do retro projetor para obter sucesso em sua utilização.

\section{d) E-mail e lista de discussões}

Esse meio tem sido amplamente utilizado em razão da agilidade de troca de informações. É adotado, especialmente nos cursos de pós-graduação, para complementar as discussões de sala de aula e trocar arquivos de texto.

\section{e) Internet}

Esse recurso é utilizado como reforço a pesquisas acadêmicas e tem eliminado as barreiras no sentido de acervo bibliográfico. As grandes bibliotecas implantaram sistemas de acesso via internet por apresentar inúmeras vantagens de custo e, sobretudo, de manutenção das obras literárias.

No caso da Contabilidade, destacam-se os sites de órgãos normatizadores da profissão, nacionais e internacionais, que trazem em seu conteúdo, matérias que auxiliam em pesquisas.

Como pôde ser visto cada método e meio didático tem suas características particulares e aplicações recomendadas a determinados contextos para atingir objetivos específicos. Constituem-se como formas de organização das condições externas à aprendizagem, a fim de 
conseguir as mudanças desejáveis no comportamento dos alunos. O conhecimento desses elementos e sua utilização enriquecem o processo de ensino-aprendizagem.

Alguns professores limitam sua atividade de ensino ao empregarem apenas um ou outro método isoladamente, sendo que muitas outras alternativas estão disponíveis. Desse modo, a partir dos estilos de aprendizagem de seus alunos, o professor pode variar os métodos e recursos a serem empregados. A sintonia entre os métodos e meios didáticos facilita a recepção e o processamento das informações e, em conseqüência, o alcance dos objetivos educacionais. 


\section{METODOLOGIA}

Nesse capítulo estão definidos o tipo de pesquisa, a amostragem, os instrumentos e procedimentos de coleta de dados e a forma como esses dados são tabulados e analisados.

A figura 4 a seguir ilustra as etapas de realização dessa pesquisa:

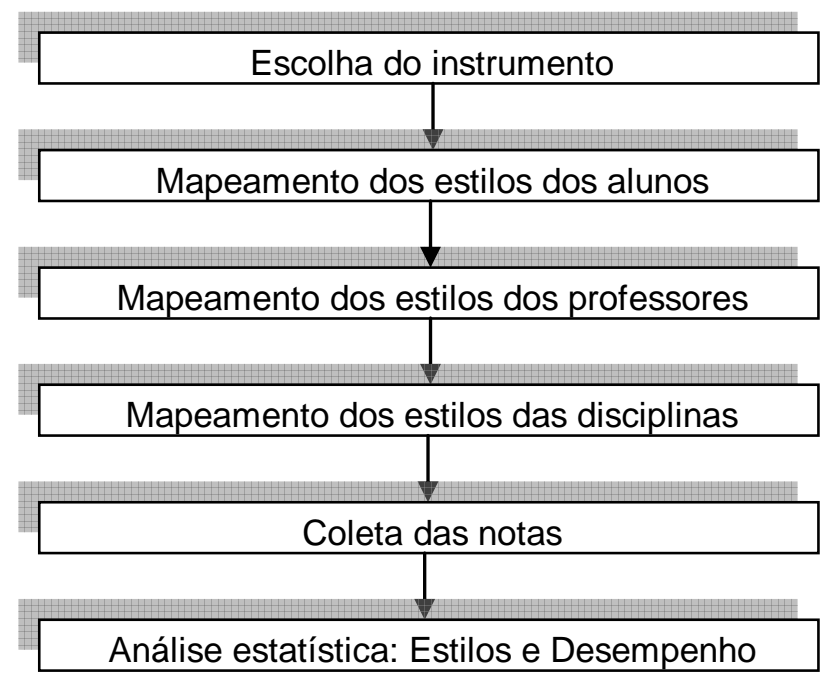

Figura 4 - Etapas da realização da pesquisa

\subsection{Tipo de pesquisa}

Do ponto de vista de seus objetivos essa pesquisa caracteriza-se como sendo uma pesquisa exploratória e descritiva. Exploratória porque visa proporcionar maior familiaridade com o problema de modo a torná-lo explícito ou a construir hipóteses, inclui levantamento bibliográfico e entrevistas. Descritiva porque descreve as características de determinada população e usa técnicas padronizadas de coleta de dados (questionários).

Quanto aos procedimentos técnicos, utiliza-se do levantamento, que envolve a interrogação direta das pessoas cujo comportamento se deseja conhecer. 
No que diz respeito à abordagem do problema é uma pesquisa predominantemente quantitativa, caracterizada pelo emprego de quantificação tanto na coleta de informações quanto no seu tratamento, por meio de técnicas estatísticas. (RICHARDSON et al., 1999: 70).

\subsection{Amostra de alunos}

Nessa pesquisa, dos 238 alunos ativos do curso de graduação em Contabilidade da FEA-RP/USP no primeiro semestre de 2006, 194 participaram do mapeamento, o que representa uma amostra de $82 \%$. É uma amostra não-probabilística acidental, composta por acaso.

Inicialmente o objetivo era pesquisar a população de alunos, mas, infelizmente, isso não foi possível em virtude de que nem todos se dispuseram a responder o questionário, mesmo após diversas solicitações e apesar de ser um questionário on-line, acessível de qualquer computador ligado à internet.

A amostra é composta por alunos que estavam cursando o $1^{\circ}, 3^{\circ}, 5^{\circ}, 7^{\circ}$ e $9^{\circ}$ semestres durante a realização da pesquisa. Na tabela 2, a seguir, pode-se observar um equilíbrio entre as quantidades de participantes dos três primeiros semestres e menor participação dos alunos dos dois últimos semestres.

Tabela 2 - Composição da amostra por semestres

\begin{tabular}{ccc}
\hline Semestre & Quantidade & Percentual \\
\hline $1^{\circ}$ & 43 & $22 \%$ \\
$3^{\circ}$ & 48 & $25 \%$ \\
$5^{\circ}$ & 43 & $22 \%$ \\
$7^{\circ}$ & 27 & $14 \%$ \\
$9^{\circ}$ & 33 & $17 \%$ \\
\hline Total & 194 & $100 \%$ \\
\hline
\end{tabular}

Na amostra há uma predominância de participantes do sexo masculino, representando $63 \%$, como visto na tabela 3. 
Tabela 3 - Composição da amostra por sexos

\begin{tabular}{ccc}
\hline Sexo & Quantidade & Percentual \\
\hline Masculino & 123 & $63 \%$ \\
Feminino & 71 & $37 \%$ \\
\hline Total & 194 & $100 \%$ \\
\hline
\end{tabular}

\subsection{Amostra de professores}

Participaram da pesquisa 29 professores que ministraram aulas no curso de graduação em Contabilidade da FEA-RP no período estudado, sendo que todos os 25 professores que estavam ministrando aulas durante o primeiro semestre de 2006 responderam os questionários.

É importante esclarecer que a FEA-RP conta, atualmente, com um corpo docente formado por 70 professores, sendo: 25 no departamento de Administração, 23 no departamento de Economia e 22 no departamento de Contabilidade. O número de professores participantes (29) é maior que o número de docentes do departamento de Contabilidade (22), porque inclui professores de outros departamentos e até mesmo de outras unidades da USP, que ministram aulas no curso de Contabilidade da FEA-RP devido às necessidades específicas de algumas disciplinas.

\subsection{Amostra de disciplinas}

Dentre as 36 disciplinas obrigatórias constantes da grade curricular do curso de graduação em Contabilidade da FEA-RP, foram analisadas 30. Somam-se a essas mais 10 disciplinas optativas da grade curricular, totalizando 40 disciplinas analisadas. 
As disciplinas que compõem a amostra da pesquisa podem ser visualizadas no quadro 11 a seguir. As disciplinas marcadas com o símbolo (*) estavam sendo oferecidas durante o período da coleta de dados ( $1^{\circ}$ semestre de 2006), que correspondem a 27 disciplinas.

\begin{tabular}{|c|c|}
\hline DISCIPLINAS OBRIGATÓRIAS & DISCIPLINAS OPTATIVAS \\
\hline $\begin{array}{c}\text { Análise das Demonstrações Contábeis } \\
\text { Análise de Custos }(*) \\
\text { Análise de Sistemas Contábeis }(*) \\
\text { Auditoria e Perícia } \\
\text { Complementos de Matemática para Contabilidade }(*) \\
\text { Comunicação Oral e Escrita }(*) \\
\text { Contabilidade Avançada }(*) \\
\text { Contabilidade de Custos } \\
\text { Contabilidade Governamental } \\
\text { Contabilidade Intermediária }(*) \\
\text { Contabilidade Introdutória I }(*) \text { e II } \\
\text { Contabilidade Tributária I }(*) \text { e II } \\
\text { Direito Empresarial }(*) \\
\text { Economia Brasileira para Administradores }(*) \\
\text { Estratégia Financeira } \\
\text { Fundamentos para Análise de Sistemas } \\
\text { Informática Aplicada }(*) \\
\text { Introdução à Probabilidade e à Estatística I e II }(*) \\
\text { Introdução à Sociologia }(*) \\
\text { Legislação Social }(*) \\
\text { Matemática Financeira }(*) \\
\text { Mercado Financeiro I }(*) \\
\text { Português Instrumental }(*) \\
\text { Teoria da Administração }(*) \\
\text { Teoria Econômica I }(*)\end{array}$ & $\begin{array}{c}\text { Análise de Liquidez }(*) \\
\text { Avaliação de Ativos }(*) \\
\text { Banco de Dados } \\
\text { Contabilidade e Responsabilidade Social }(*) \\
\text { Contabilidade Rural } \\
\text { Contabilometria } \\
\text { Controladoria e Risco de Instituições Financeiras } \\
\text { Práticas Governança Corporativa Inf. Contábeis }(*) \\
\text { Tópicos de Contabilidade Internacional }(*) \\
\text { Tópicos de Informática aplicados à Contabilidade }(*)\end{array}$ \\
\hline
\end{tabular}

Quadro 11 - Composição da amostra das disciplinas

\subsection{Médias das notas das disciplinas}

Para fins exclusivos desta pesquisa, a seção de graduação da FEA-RP disponibilizou o histórico escolar completo de todos os alunos do curso de Contabilidade, contendo todas as médias das notas obtidas nas avaliações de cada disciplina cursada. O período incluído na análise foi do ano de 2000 até o primeiro semestre de 2006. 
Do arquivo geral do histórico escolar foram excluídos todos os alunos desistentes, com matrículas trancadas, sem notas e sem freqüência e, por fim, os alunos que não participaram do mapeamento dos estilos de aprendizagem.

Em seguida, foi feita uma verificação das disciplinas constantes do histórico, pois, ao longo dos anos, algumas disciplinas tiveram suas nomenclaturas alteradas, deixaram de existir, tornando-se equivalentes a outras disciplinas, com códigos e nomenclaturas diferentes, e outras foram incluídas na grade curricular. Com isso, a cada versão de determinada disciplina, eram geradas informações idênticas e repetidas, as quais foram excluídas do arquivo, permanecendo apenas uma informação válida de cada aluno e média.

Na seqüência foi realizada a uniformização das disciplinas equivalentes para que todas as médias correspondessem a disciplinas com mesmo código e nomenclatura das versões atualizadas e vigentes. Depois disso, foram excluídas do histórico todas as médias referentes às disciplinas não pertencentes à amostra analisada e todas as médias referentes às disciplinas que foram ministradas por mais de um professor durante um mesmo período, ou ministradas por professores não participantes da pesquisa.

$\mathrm{Na}$ análise de desempenho acadêmico foi considerada a primeira média de nota obtida pelos alunos, antes das reavaliações. No caso de reprovações, também foi considerada unicamente a primeira média.

É importante destacar que a nota é apenas um dos fatores que refletem o desempenho do aluno e, portanto as interpretações acerca dos resultados dessa pesquisa devem ser feitas com a cautela que toda pesquisa exploratória exige. A nota não reflete, necessariamente, a aprendizagem, que é decorrente do processo de ensino-aprendizagem e envolve três elementos essenciais: aluno, professor e disciplina. Outro ponto importante é o estilo de prova (avaliação) elaborada e aplicada aos alunos pelos professores, que também pode favorecer determinados estilos de aprendizagem e influenciar a nota. 


\subsection{Coleta de dados}

Para concretização da pesquisa, inicialmente realizou-se o mapeamento dos estilos de aprendizagem dos alunos utilizando-se o Índice de Estilos de Aprendizagem de FelderSoloman (1991), que segue sistemas internacionais na identificação dos estilos de aprendizagem de cada indivíduo. Os resultados do ILS fornecem uma indicação das preferências individuais de aprendizagem, e uma indicação ainda melhor do perfil de preferências de um grupo de estudantes.

O mapeamento foi realizado durante os meses de março a junho de 2006. Por meio do contato pessoal direto com os alunos nas aulas, foi solicitado que eles disponibilizassem um endereço de e-mail para que pudessem ser enviados o nome de usuário (login) e a senha de acesso ao questionário on-line, ambos fornecidos pelos pesquisadores e desenvolvedores do sistema da EESC/USP. Feito isso, os alunos responderam ao questionário e suas respostas ficaram armazenadas no banco de dados da EESC.

Esse sistema realiza a comparação das respostas de acordo com o Modelo de FelderSilverman (1988) que traça o perfil dos estilos de aprendizagem. Em seguida, para acessar os estilos dos alunos, utilizou-se login e senha específicos, também fornecidos pelos desenvolvedores do sistema.

A coleta dos estilos dos professores procedeu-se de forma semelhante a dos alunos, durante os meses de março a julho de 2006, com apenas mais um detalhe: aos professores foi solicitado, ao mesmo tempo, que respondessem um questionário relativo ao estilo das disciplinas (Apêndice B).

Esse questionário foi elaborado com o objetivo de possibilitar a identificação dos estilos das disciplinas ministradas, dentro das quatro dimensões do ILS de Felder-Soloman (1991), com base nos métodos e meios didáticos utilizados pelos professores. O questionário 
é composto das dimensões do modelo, com uma breve descrição das características principais de cada categoria de estilo, fazendo relação entre essas características e as metodologias adotadas nas disciplinas. Desse modo, os professores puderam escolher, dentre as dimensões, qual categoria concluiu ser mais conveniente para identificar o estilo de determinada disciplina.

O desempenho dos alunos foi mensurado pelas médias das notas obtidas nas avaliações. Em termos de precisão metodológica, como forma de tornar a pesquisa direcionada e objetiva, ficou definido que ela se atém às médias das notas obtidas pelos alunos a partir das regras de avaliação determinadas pelos professores e pela instituição.

De posse dos dados necessários, passou-se para a etapa de análise.

\subsection{Procedimentos de análise dos dados}

As variáveis da pesquisa receberam tratamento de análise estatística descritiva e multivariada. A estatística descritiva foi realizada para caracterizar os estilos de aprendizagem das amostras estudadas e, a multivariada, para verificar o impacto dos estilos de aprendizagem no desempenho acadêmico dos alunos.

Foi utilizada a técnica de análise de variância (ANOVA) para análises univariadas e análise de variância (ANOVA) multifatorial, para multivariada, com auxílio do software estatístico SPSS - Statistical Package for the Social Sciences.

A análise de variância proporciona condições de determinar se as amostras de dois ou mais grupos surgem de populações com médias iguais. A análise de variância multifatorial permite examinar os efeitos de diversas variáveis independentes sobre a variável ou variáveis dependentes. São encontrados os efeitos de cada variável independente sobre a variável 
dependente, chamados de efeitos principais, e os efeitos conjuntos de variáveis independentes sobre as variáveis dependentes, chamados de efeitos de interação.

Conforme Hair et al. (2005, p. 286) a técnica de análise de variância exige que as observações em determinada amostra sejam independentes, isto é, que as medidas dependentes para cada respondente (no caso, as médias das notas) sejam totalmente nãocorrelacionadas com as medidas de outros respondentes na amostra.

Isso significa que determinado aluno não poderia ser considerado mais de uma vez na mesma amostra. Contudo, nessa pesquisa foram analisadas 40 disciplinas, com características e exigências (estilos) diferentes, ministradas por professores também com estilos diferentes ao longo dos semestres, fato este que, se ignorado, poderia prejudicar o objetivo do trabalho. Sendo assim, na amostra foram consideradas todas as notas dos alunos nas 40 disciplinas analisadas.

Para evitar que uma falta de independência possa afetar severamente a validade estatística da análise, existem algumas ações corretivas a serem realizadas, pois, segundo Hair et al. (2005, p. 287), mesmo mantida a suposição de independência, não há testes com uma certeza absoluta de detectar todas as formas de dependência. Com isso, foi adotado um nível de significância, alfa $(\alpha) \leq 0,05$, ou seja, $\mathrm{p} \leq 0,05$.

Nas comparações post hoc utilizou-se o método de Bonferroni (HALL, NEVES \& PEREIRA, 2006: 241). Esse método fornece testes de cada combinação de grupos, facilitando a interpretação dos resultados, além de ser conservador em relação ao erro Tipo I, ou seja, a probabilidade de rejeitar uma hipótese nula quando ela é verdadeira. A fim de garantir a validade da análise, essa técnica é usada para ajustar o nível alfa selecionado de modo a controlar a taxa de erro Tipo I.

Definido o alfa, o elemento final que afeta o poder estatístico da análise é o tamanho da amostra. Em geral, uma amostra majorada reduz o erro amostral e aumenta o poder do 
teste. No entanto, é necessário cautela, pois, quando as amostras se tornam grandes e a significância estatística é indicada, deve-se examinar o poder e os tamanhos de efeito para garantir não apenas a significância estatística, mas também a prática.

Os resultados obtidos com a aplicação das ferramentas estatísticas são expostos e analisados em seguida. 


\section{$5 \quad$ RESULTADOS E ANÁLISE DOS RESULTADOS}

Nesse capítulo são apresentados e analisados os resultados obtidos com a aplicação dos instrumentos e ferramentas estatísticas.

Inicialmente é feita a análise quantitativa dos dados, com verificação dos números absolutos e percentuais obtidos nas variáveis analisadas, que permite a identificação dos estilos predominantes entre os alunos, professores e disciplinas do curso de graduação em Contabilidade da FEA-RP (análise descritiva). Logo após é feita a análise do impacto dos estilos de aprendizagem no desempenho acadêmico dos alunos, com a utilização do método de análise de variância (ANOVA).

Em seguida, é realizada a análise qualitativa onde é discutido o impacto dos resultados observados no processo de ensino-aprendizagem e sugeridas algumas estratégias instrucionais julgadas mais adequadas aos estilos identificados. Essa análise demonstra como o ensino de Contabilidade pode ser favorecido a partir do conhecimento dos estilos de aprendizagem dos alunos e professores e dos estilos das disciplinas.

\subsection{Estilos de aprendizagem dos alunos}

Com a apuração das respostas de todos os alunos participantes da pesquisa é possível conhecer os estilos de aprendizagem dominantes na amostra. As freqüências absolutas e relativas estão especificadas na tabela 4.

Observando a tabela, constata-se que o perfil dos alunos do curso de graduação em Contabilidade da FEA-RP é composto, predominantemente, dos estilos: ativo, sensorial, visual e seqüencial. Verifica-se, ainda, que na dimensão seqüencial/global existe um maior equilíbrio na preferência entre um estilo e outro do que o observado nas outras dimensões. 
Tabela 4 - Estilos de aprendizagem dos alunos

\begin{tabular}{ccr}
\hline Estilos & Quantidade & Percentual \\
\hline Ativo & 114 & $58,76 \%$ \\
Reflexivo & 80 & $41,24 \%$ \\
Sensorial & 153 & $78,87 \%$ \\
Intuitivo & 41 & $21,13 \%$ \\
Visual & 138 & $71,13 \%$ \\
Verbal & 56 & $28,87 \%$ \\
Seqüencial & 102 & $52,58 \%$ \\
Global & 92 & $47,42 \%$ \\
\hline
\end{tabular}

Esses resultados são semelhantes aos encontrados por Bertolini (2005), que também pesquisou os alunos de Contabilidade da FEA-RP, porém com uma amostra menor. Exceto a dimensão seqüencial/global, que no estudo de Bertolini não apresentou um equilíbrio tão expressivo como no atual, todas as outras dimensões obtiveram resultados muito próximos.

O gráfico 1 ilustra a distribuição percentual dos estilos de aprendizagem entre os 194 alunos presentes na amostra:

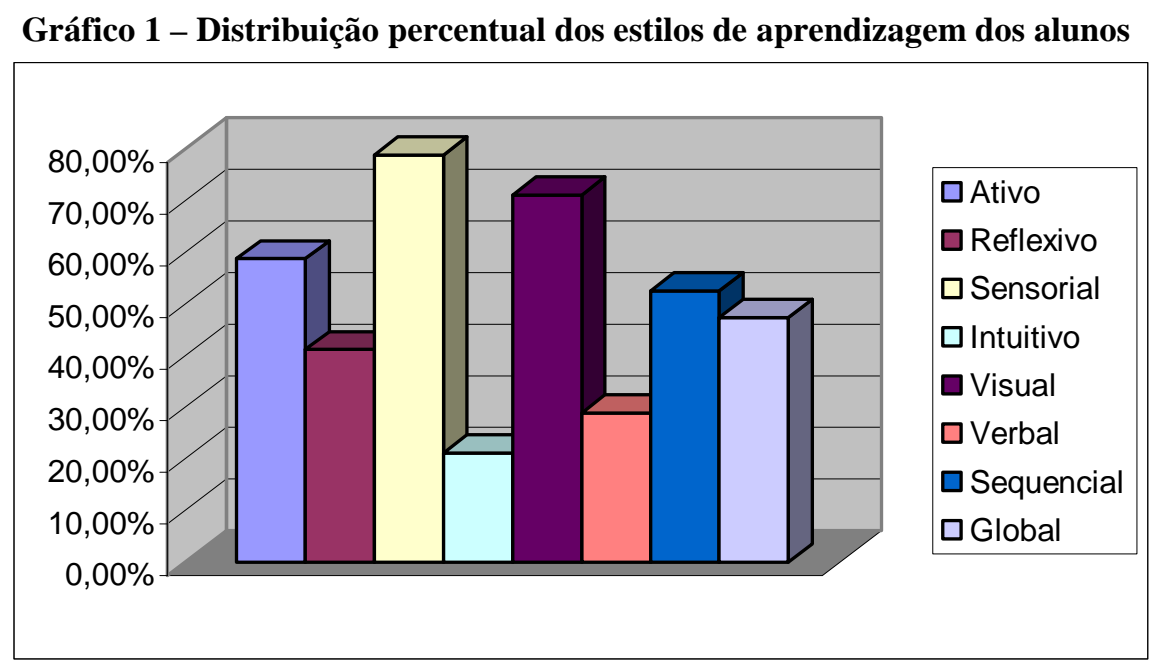

Com relação à dimensão ativo/reflexivo, relacionada ao processamento da informação, pode-se dizer que 58,76\% dos alunos do curso de Contabilidade da FEA-RP tendem a compreender e reter melhor a informação trabalhando de modo ativo - discutindo, aplicando ou explicando a informação para outros - do que refletindo quietamente. Os estudantes com estilo ativo gostam mais do trabalho em grupo do que os reflexivos, que preferem trabalhar sozinhos. 
O gráfico 2 mostra o comportamento dos resultados dessa dimensão em escala, na qual os escores 1A a 11A se referem ao estilo ativo e os escores 1B a 11B ao reflexivo.

Gráfico 2 - Dimensão ativo/reflexivo em escala

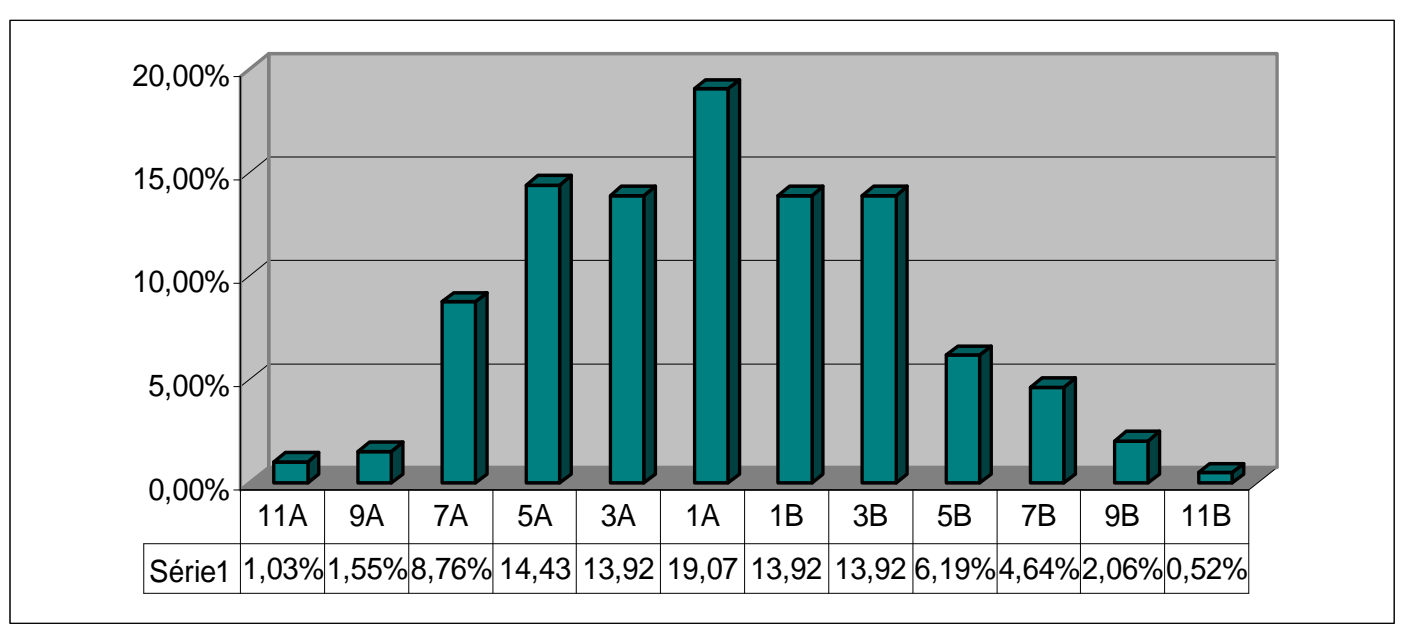

Como já mencionado, de acordo com o ILS de Felder, uma pontuação de 1 a 3 na escala revela preferência leve por um estilo; uma pontuação de 5 a 7 , indica preferência moderada e de 9 a 11, forte. O gráfico demonstra uma maior concentração de ativos com preferência leve e moderada e um número muito inferior com preferência forte. Com os reflexivos é parecido, ou seja, a maioria tem preferência leve e moderada.

Desse modo, é possível dizer que para essa dimensão existe certo equilíbrio entre as duas categorias de estilos, pois, como visto no gráfico 2, os estilos estão agrupados no centro, o que implica em facilidade de adaptação a diferentes metodologias de ensino.

Na dimensão sensorial/intuitivo, relativa à percepção da informação, há o domínio do estilo sensorial $(78,87 \%)$, ou seja, a maioria dos alunos prefere aprender fatos e resolver problemas por meio de métodos bem estabelecidos, sem complicações e surpresas. Contrariamente, um menor percentual de intuitivos gosta de novidade, de descobrir possibilidades e relações e se aborrece com a repetição.

Ao observar o gráfico 3, a seguir, nota-se que essa dimensão é a que mais evidencia a preferência por uma das categorias, que é a sensorial, revelando grande concentração nas preferências leve e moderada e um número razoável de alunos fortemente sensoriais (1A a 
11A). Já os intuitivos aparecem em quantidade bem menor, não tendo nenhum aluno fortemente intuitivo na amostra (1B a 11B).

Gráfico 3 - Dimensão sensorial/intuitivo em escala

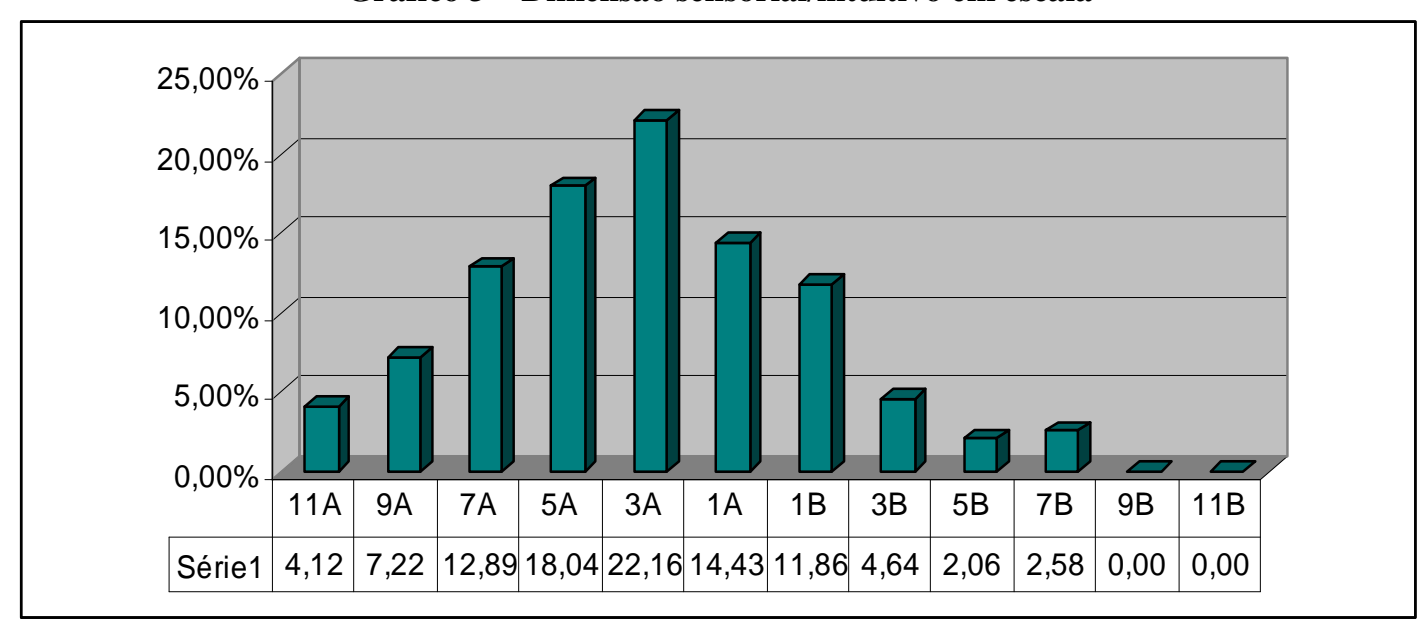

Os resultados dessa dimensão não surpreendem, pois o curso de Contabilidade tem um caráter objetivo e sistemático, o que requer dos estudantes a memorização de fórmulas e regras tradicionais em detrimento da inovação do raciocínio.

No curso de Contabilidade da FEA-RP existem mais aprendizes visuais do que verbais. Isso quer dizer que $71,13 \%$ dos alunos se lembram melhor do que viram - figuras, diagramas, fluxogramas, filmes e demonstrações. Os aprendizes verbais conseguem tirar maior proveito das palavras - explanações escritas ou faladas. A dimensão visual/verbal diz respeito à maneira como as pessoas recebem e retém as informações externas.

Essa maior quantidade de aprendizes visuais não foi observada somente no curso de Contabilidade. Lopes (2002) também identificou predominância de estudantes com estilo visual em cursos na área de Ciências Exatas (79\%) e Kuri (2004) revelou em seu estudo que quase $84 \%$ dos estudantes de engenharia são visuais.

O gráfico 4 apresenta os resultados em escala, sendo os escores $1 \mathrm{~A}$ a $11 \mathrm{~A}$ correspondentes a dimensão visual e 1B a 11B, correspondentes à dimensão verbal. 


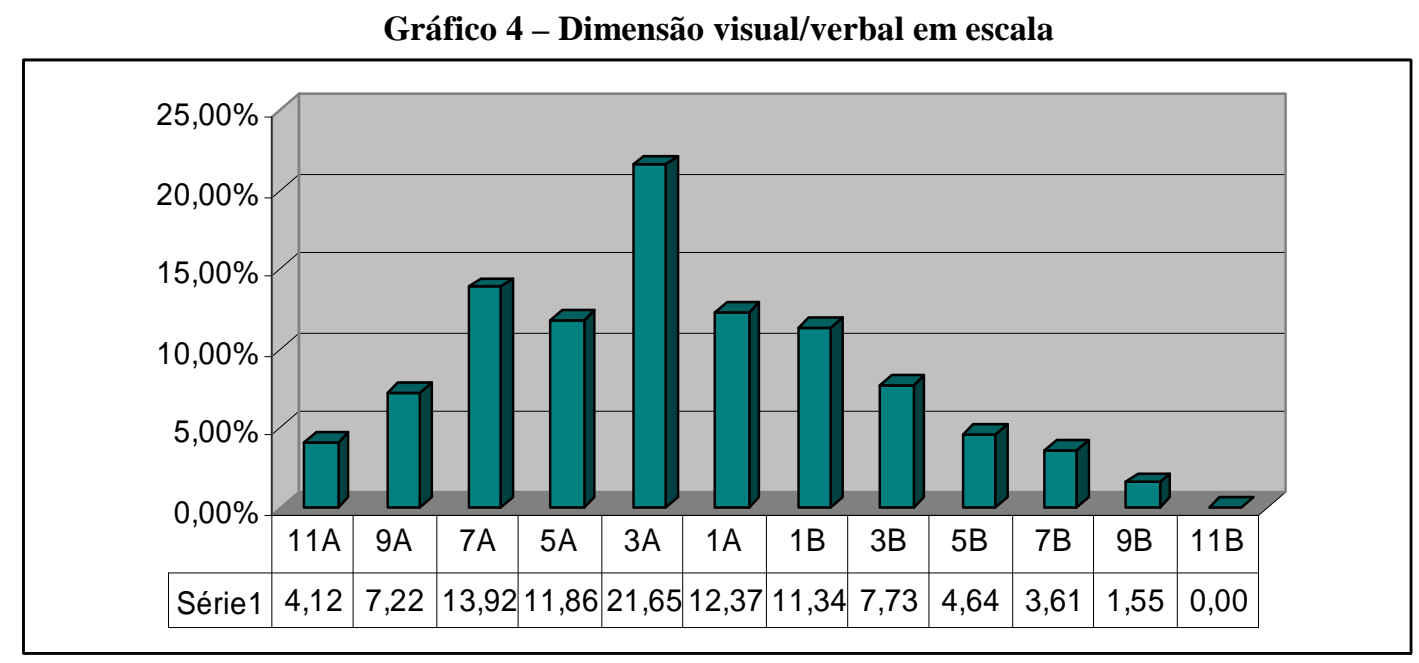

Novamente fica clara a concentração do lado esquerdo do gráfico, representando os aprendizes visuais, com maior número revelando preferência leve. Do lado direito estão os verbais, em número bem menor.

Em se tratando da dimensão seqüencial/global, ligada ao modo como as pessoas estruturam e compreendem a informação, tem-se, visualmente, uma quantidade mais significativa de aprendizes seqüenciais, embora seja uma diferença pequena entre os dois estilos, se comparado às outras três dimensões. Isso significa que 52,58\% dos alunos preferem aprender de forma linear, em etapas logicamente seqüenciadas, do que aprender em grandes saltos, como os globais, que assimilam o material quase aleatoriamente, sem ver as conexões e, repentinamente, compreendem tudo.

Pela representação dos resultados em escala (gráfico 5), observa-se o equilíbrio dessa dimensão. Do lado esquerdo está a dimensão seqüencial (escores 1A a 11A) e do lado direito, a dimensão global (escores 1B a 11B).

Novamente, com os estilos agrupados no centro, é possível que se encontre facilidade de adaptação a diversas metodologias de ensino e às características ou exigências das disciplinas (estilos), já que algumas disciplinas do curso de Contabilidade podem ter características mais ligadas à legislação e às escolas de pensamento contábil italianas, muito 
mais normativas e com etapas seqüenciadas, e outras se relacionam às características das escolas norte-americanas, mais voltadas à gestão e à visão global.

Gráfico 5 - Dimensão seqüencial/global em escala

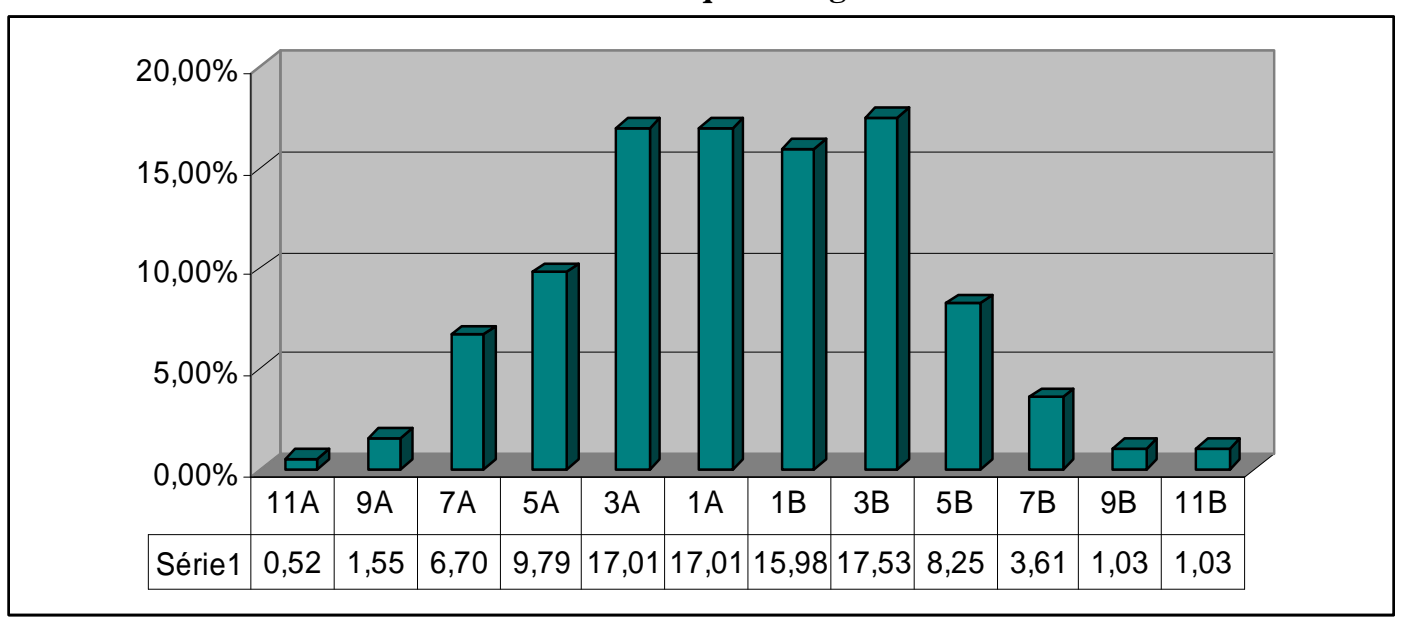

Terminada a identificação dos estilos de aprendizagem dos alunos e feitas algumas observações sobre estes, passa-se a identificação dos estilos dos professores.

\subsection{Estilos de aprendizagem dos professores}

Pelos resultados, os estilos de aprendizagem dominantes na maioria dos professores do curso de Contabilidade da FEA-RP são: reflexivo, intuitivo, visual e seqüencial, como mostra a tabela 5 .

Esses resultados demonstram que em duas dimensões - ativo/reflexivo e sensorial/intuitivo - os estilos de aprendizagem predominantes nos professores são opostos aos dos alunos. Enquanto os alunos do curso de Contabilidade da FEA-RP são mais ativos e sensoriais, os professores são mais reflexivos e intuitivos.

As outras dimensões apresentam resultados muito semelhantes aos obtidos com os alunos, até mesmo o grande equilíbrio na dimensão seqüencial/global. 
Tabela 5 - Estilos de aprendizagem dos professores

\begin{tabular}{ccc}
\hline Estilos & Quantidade & Percentual \\
\hline Ativo & 10 & $34,48 \%$ \\
Reflexivo & 19 & $65,52 \%$ \\
Sensorial & 14 & $48,28 \%$ \\
Intuitivo & 15 & $51,72 \%$ \\
Visual & 21 & $72,41 \%$ \\
Verbal & 8 & $27,59 \%$ \\
Seqüencial & 15 & $51,72 \%$ \\
Global & 14 & $48,28 \%$ \\
\hline
\end{tabular}

Como dito anteriormente, de acordo com Felder-Silverman (1988), os estilos de aprendizagem estão relacionados aos estilos de ensinar.

Seguindo o Modelo de Felder-Silverman (1988), o fato de os professores terem um estilo reflexivo, corresponde à expectativa de participação dos alunos durante as aulas, isto é, os reflexivos esperam alunos passivos, que assistem e escutam.

Os professores intuitivos dão mais ênfase à informação conceitual e teórica, enquanto os sensoriais enfatizam mais a informação concreta.

Como a maior parte dos professores é visual, observa-se que eles utilizam esquemas, figuras, gráficos e outras ilustrações durante as aulas expositivas, inclusive projeção de slides com o auxílio do projetor multimídia.

O estilo seqüencial, mais presente entre os professores, faz com que eles prefiram apresentar a informação passo a passo, linearmente. De forma oposta trabalham os globais, apresentando a informação sob a perspectiva global.

O gráfico 6 ilustra os percentuais de estilos identificados entre os professores: 
Gráfico 6 - Distribuição percentual dos estilos de aprendizagem dos professores

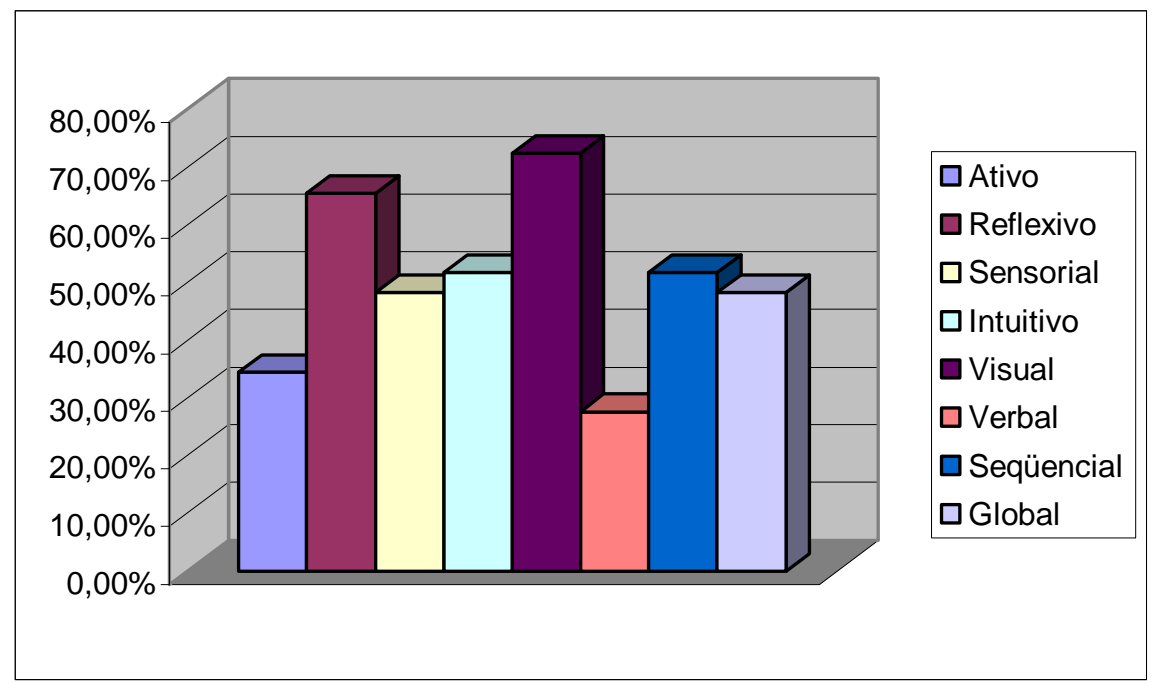

A distribuição dos estilos dos professores e o relacionamento entre estes, os estilos das disciplinas e as metodologias didáticas utilizadas estão expostos no Apêndice B.

Na sequiência são descritos os estilos das disciplinas.

\subsection{Estilos das disciplinas}

A tabela 6 apresenta as freqüências absolutas e relativas dos estilos das disciplinas:

Tabela 6 - Estilos de aprendizagem das disciplinas

\begin{tabular}{ccc}
\hline Estilos & Quantidade & Percentual \\
\hline Ativa & 19 & $47,50 \%$ \\
Reflexiva & 21 & $52,50 \%$ \\
Sensorial & 31 & $77,50 \%$ \\
Intuitiva & 9 & $22,50 \%$ \\
Visual & 18 & $45,00 \%$ \\
Verbal & 22 & $55,00 \%$ \\
Seqüencial & 30 & $75,00 \%$ \\
Global & 10 & $25,00 \%$ \\
\hline
\end{tabular}

Observando a tabela, verifica-se que a maior parte das disciplinas foi classificada como reflexiva, sensorial, verbal e seqüencial.

O questionário que foi entregue aos professores continha uma descrição das características que as disciplinas deveriam ter para ser classificadas em determinado estilo (ver Apêndice B). Partindo desse ponto, é possível dizer que uma disciplina é reflexiva 
quando implica em predominância de reflexões nos assuntos antes de discussões ou aplicações práticas e realização de trabalhos individuais. As disciplinas ativas são caracterizadas pelo predomínio de discussões, aplicações práticas e experimentais e trabalhos em grupo.

As disciplinas do curso de graduação em Contabilidade da FEA-RP são mais sensoriais porque empregam mais a resolução de problemas com procedimentos bem estabelecidos, memorização e trabalhos experimentais. Já as disciplinas intuitivas, apenas 22,5\%, utilizam mais fórmulas matemáticas, abstrações e inovações, com pouca memorização e poucas repetições.

Possuem estilo verbal as disciplinas cujas aulas são ministradas de forma escrita e falada, contrariamente às aulas mais simbólicas, que se utilizam de gráficos, filmes, quadros, diagramas, esquemas etc. e que caracterizam as disciplinas com estilo visual.

A predominância de resolução de problemas em etapas graduais e lógicas marca a existência de um número mais expressivo de disciplinas seqüenciais no curso de graduação em Contabilidade da FEA-RP/USP. Pelo que se pôde constatar, apenas 25\% das disciplinas tem estilo global, caracterizado pela resolução de problemas a partir da visão geral, do todo, e de forma aleatória.

Realizadas as discussões iniciais sobre os estilos dos alunos, professores e disciplinas, seguem as análises sobre o impacto desses estilos no desempenho acadêmico dos alunos.

\subsection{0 impacto dos estilos de aprendizagem no desempenho acadêmico dos alunos}

Esse tópico inclui a análise do impacto dos estilos de aprendizagem de cada fator aluno, professor e disciplina - separadamente e em conjunto, sobre o desempenho acadêmico 
dos alunos, para todas as dimensões de estilos verificadas de acordo com o ILS de FelderSoloman (1991).

\subsubsection{Dimensão ativo/reflexivo}

Os resultados dessa dimensão mostraram que os estilos dos alunos e das disciplinas considerados individualmente, não exercem influência sobre o desempenho acadêmico. Isso quer dizer que os alunos obtiveram desempenho semelhante, independentemente de serem ativos ou reflexivos. O mesmo ocorre com as disciplinas, ou seja, o fato de determinada disciplina ser ativa ou reflexiva, não influenciou o desempenho dos alunos.

No que diz respeito aos professores, nessa dimensão foi encontrada diferença entre os estilos ativo e reflexivo em relação ao nível de significância adotado ( $\mathrm{p} \leq 0,05)$, o que demonstrou que os alunos cujos professores são reflexivos, obtiveram médias significativamente superiores.

Essa constatação é reforçada pela análise multivariada o que é apresentado na tabela 7:

Tabela 7 - ANOVA multifatorial para dimensão ativo/reflexivo (variável dependente: nota)

\begin{tabular}{l|r|r|r|r|r}
\hline \multicolumn{1}{c|}{ Fonte } & $\begin{array}{c}\text { Soma dos } \\
\text { Quadrados }\end{array}$ & g.l. & $\begin{array}{c}\text { Quadrado } \\
\text { Médio }\end{array}$ & F & \multicolumn{1}{c}{ p } \\
\hline ALUNO & 0,141 & 1 & 0,141 & 0,038 & 0,846 \\
DISCIPLINA & 1,140 & 1 & 1,140 & 0,036 & 0,580 \\
PROFESSOR & 35,272 & 1 & 35,272 & 9,474 & 0,002 \\
ALUNO*DISC. & 7,722 & 1 & 7,722 & 2,074 & 0,150 \\
ALUNO*PROF. & 0,680 & 1 & 0,680 & 0,183 & 0,669 \\
DISC.*PROF. & 6,575 & 1 & 6,575 & 1,766 & 0,184 \\
ALUNO*DISC.*PROF. & 18,102 & 1 & 18,102 & 4,862 & 0,028 \\
Erro & 11671,464 & 3135 & 3,723 & & \\
Correlação Total & 11728,616 & 3142 & & & \\
\hline
\end{tabular}

Os resultados indicam que o estilo ativo ou reflexivo do professor exerce influência sobre as notas dos alunos (desempenho). A interação de $3^{a}$ ordem foi significativa $(p=0,028)$, o que mostra que a diferença na média obtida com professores ativos ou reflexivos sofre 
variações conforme se alteram, simultaneamente, as classificações de aluno e disciplina. A influência dessa interação é melhor visualizada na tabela 8:

Tabela 8 - Combinações possíveis para ativo/reflexivo

\begin{tabular}{|c|c|c|c|}
\hline ALUNO & DISCIPLINA & PROFESSOR & Média \\
\hline \multirow[t]{4}{*}{ Ativo } & ativa & Ativo & 6,709 \\
\hline & & Reflexivo & 6,855 \\
\hline & reflexiva & Ativo & 6,564 \\
\hline & & Reflexivo & 6,854 \\
\hline \multirow[t]{4}{*}{ Reflexivo } & ativa & Ativo & 6,390 \\
\hline & & Reflexivo & 6,968 \\
\hline & reflexiva & Ativo & 6,844 \\
\hline & & Reflexivo & 6,842 \\
\hline
\end{tabular}

Na tabela é possível observar que a maior média foi obtida por alunos reflexivos, cursando disciplina ativa com professor reflexivo $(6,968)$.

Esse resultado contradiz a suposição inicial de que o desempenho acadêmico de um aluno com determinado estilo de aprendizagem seria favorecido por uma combinação de disciplina e professor com igual estilo, mostrando que a disciplina com estilo oposto pode estimular um melhor desempenho.

\subsubsection{Dimensão sensorial/intuitivo}

Para a dimensão sensorial/intuitivo foi constatado que os alunos com estilo de aprendizagem sensorial obtiveram médias significativamente superiores às obtidas por alunos com estilo intuitivo. Já com relação às disciplinas, as que foram classificadas como intuitivas tiveram as maiores médias.

Os testes da análise multivariada comprovam esses resultados e revelam que, quando as variáveis são consideradas em conjunto, o estilo do professor também exerce influência sobre as médias nessa dimensão. A interação de $2^{\mathrm{a}}$ ordem entre o estilo da disciplina e o estilo do professor impacta o desempenho ( $\mathrm{p}<0,001$ ). Tais resultados são expressos na tabela 9: 
Tabela 9 - ANOVA multifatorial para dimensão sensorial/intuitivo (variável dependente: nota)

\begin{tabular}{l|r|r|r|r|r}
\hline \multicolumn{1}{c|}{ Fonte } & $\begin{array}{r}\text { Soma dos } \\
\text { Quadrados }\end{array}$ & g.l. & $\begin{array}{c}\text { Quadrado } \\
\text { Médio }\end{array}$ & \multicolumn{1}{c|}{ F } & \multicolumn{1}{c}{ p } \\
\hline ALUNO & 45,848 & 1 & 45,848 & 12,774 & 0,000 \\
DISCIPLINA & 177,853 & 1 & 177,853 & 49,554 & 0,000 \\
PROFESSOR & 96,371 & 1 & 96,371 & 26,851 & 0,000 \\
ALUNO*DISC. & 1,497 & 1 & 1,497 & 0,417 & 0,518 \\
ALUNO*PROF. & 10,477 & 1 & 10,477 & 2,919 & 0,088 \\
DISC.*PROF. & 133,150 & 1 & 133,150 & 37,099 & 0,000 \\
ALUNO*DISC.*PROF. & 11,482 & 1 & 11,482 & 3,199 & 0,074 \\
Erro & 11251,665 & 3135 & 3,589 & & \\
Correlação Total & 11728,616 & 3142 & & & \\
\hline
\end{tabular}

Ainda na tabela 9 é possível observar que há uma tendência de que os estilos dos alunos, professores e disciplinas, nessa dimensão, impactam o desempenho acadêmico dos alunos, como indica a interação de $3^{\mathrm{a}}$ ordem, com uma significância de 0,074 , muito próxima do nível adotado $(0,05)$.

As análises mostram que quando os professores são intuitivos, os alunos do curso de Contabilidade conseguem obter médias mais altas do que quando os professores têm o estilo de aprendizagem classificado como sensorial. A interação significativa demonstra que a combinação de uma disciplina intuitiva com professor intuitivo promove um melhor desempenho por parte dos alunos, do que uma disciplina sensorial com professor intuitivo.

Ao examinar as médias obtidas em cada diferente interação entre sensoriais e intuitivos, obtém-se que a média mais alta resulta da combinação de estilo intuitivo para os três fatores: aluno, professor e disciplina. Contudo, é observada média alta, também, para a combinação aluno sensorial, disciplina e professor intuitivos, evidenciando o resultado da análise univariada, onde os alunos sensoriais aparecem com médias significativamente superiores. A menor média está na combinação disciplina sensorial, aluno e professor intuitivos. Essas informações são resumidas na tabela 10: 
Tabela 10 - Combinações possíveis para sensorial/intuitivo

\begin{tabular}{|c|c|c|c|}
\hline ALUNO & DISCIPLINA & PROFESSOR & Média \\
\hline \multirow[t]{4}{*}{ Intuitivo } & intuitiva & Intuitivo & 7,920 \\
\hline & & Sensorial & 6,368 \\
\hline & sensorial & Intuitivo & 6,285 \\
\hline & & Sensorial & 6,389 \\
\hline \multirow[t]{4}{*}{ Sensorial } & intuitiva & Intuitivo & 7,860 \\
\hline & & Sensorial & 7,043 \\
\hline & sensorial & Intuitivo & 6,737 \\
\hline & & Sensorial & 6,824 \\
\hline
\end{tabular}

\subsubsection{Dimensão visual/verbal}

Os testes da análise de variância mostraram que para essa dimensão foi encontrada diferença estatisticamente significativa nas médias das notas quando considerados os estilos de aprendizagem dos alunos. Os alunos com estilo de aprendizagem verbal apresentam médias significativamente superiores às médias obtidas pelos alunos com estilo visual. Considerando os estilos das disciplinas e dos professores, separadamente, constata-se que essas variáveis não influenciaram as médias dos alunos.

A tabela 11, a seguir, representa a análise de variância multifatorial:

Tabela 11 - ANOVA multifatorial para dimensão visual/verbal (variável dependente: nota)

\begin{tabular}{l|r|r|r|r|r}
\hline \multicolumn{1}{c|}{ Fonte } & $\begin{array}{r}\text { Soma dos } \\
\text { Quadrados }\end{array}$ & g.l. & $\begin{array}{c}\text { Quadrado } \\
\text { Médio }\end{array}$ & \multicolumn{1}{c|}{ F } & \multicolumn{1}{c}{ p } \\
\hline ALUNO & 80,244 & 1 & 80,244 & 21,763 & 0,000 \\
DISCIPLINA & 4,214 & 1 & 4,214 & 1,143 & 0,285 \\
PROFESSOR & 0,412 & 1 & 0,412 & 0,112 & 0,738 \\
ALUNO*DISC. & $7,000 E-02$ & 1 & $7,000 \mathrm{E}-02$ & 0,020 & 0,887 \\
ALUNO*PROF. & 2,981 & 1 & 2,981 & 0,808 & 0,369 \\
DISC.*PROF. & 36,242 & 1 & 36,242 & 9,829 & 0,002 \\
ALUNO*DISC.*PROF. & 2,951 & 1 & 2,951 & 0,800 & 0,371 \\
Erro & 11559,457 & 3135 & 3,687 & & \\
Correlação Total & 11728,616 & 3142 & & & \\
\hline
\end{tabular}

A análise multivariada confirma o impacto dos estilos de aprendizagem dos alunos no seu desempenho e revela que a interação entre as variáveis estilo da disciplina e estilo do professor também impacta nas notas. Veja a tabela 12 na sequiência: 
Tabela 12 - Interação entre disciplina e professor na dimensão visual/verbal

\begin{tabular}{ll|c|r}
\hline DISCIPLINA & PROFESSOR & Média & Erro padrão \\
\hline Verbal & Verbal & 6,809 & 0,073 \\
& Visual & 7,085 & 0,075 \\
\hline Visual & Verbal & 6,973 & 0,097 \\
& Visual & 6,750 & 0,070 \\
\hline
\end{tabular}

Pelos resultados, verifica-se que a maior média é obtida quando a disciplina é verbal e o professor é visual. Além disso, é possível observar que a segunda maior média, obtida com o inverso da combinação, ou seja, disciplina visual e professor verbal, fica muito próxima da primeira.

A combinação entre os três elementos é apresentada na tabela 13:

Tabela 13 - Combinações possíveis para visual/verbal

\begin{tabular}{|c|c|c|c|}
\hline ALUNO & DISCIPLINA & PROFESSOR & Média \\
\hline \multirow[t]{4}{*}{ Verbal } & \multirow[t]{2}{*}{ verbal } & Verbal & 7,059 \\
\hline & & Visual & 7,193 \\
\hline & \multirow[t]{2}{*}{ visual } & Verbal & 7,164 \\
\hline & & Visual & 6,941 \\
\hline \multirow[t]{4}{*}{ Visual } & \multirow[t]{2}{*}{ verbal } & Verbal & 6,557 \\
\hline & & Visual & 6,976 \\
\hline & \multirow[t]{2}{*}{ visual } & Verbal & 6,781 \\
\hline & & Visual & 6,559 \\
\hline
\end{tabular}

A tabela evidencia que a maior média é obtida por um aluno verbal, cursando uma disciplina verbal, ministrada por um professor visual. Mais uma vez uma combinação de estilos diferentes resulta na média mais alta.

\subsubsection{Dimensão seqüencial/global}

Das quatro dimensões avaliadas pelo ILS de Felder-Soloman (1991), a dimensão seqüencial/global foi a que mais evidenciou impacto no desempenho acadêmico dos alunos do curso de graduação em Contabilidade da FEA-RP.

Todas as análises univariadas dessa dimensão demonstraram a influência das variáveis estilos dos alunos, professores e disciplinas sobre as notas, como visto na tabela 14 . 
Tabela 14 - Análises univariadas para a dimensão seqüencial/global

\begin{tabular}{l|r|r|r|r|r}
\hline \multicolumn{1}{c|}{ Fonte } & $\begin{array}{r}\text { Soma dos } \\
\text { Quadrados }\end{array}$ & g.l. & $\begin{array}{c}\text { Quadrado } \\
\text { Médio }\end{array}$ & F & \multicolumn{1}{c}{ p } \\
\hline ALUNO & 45,045 & 1 & 45,045 & 12,11 & 0,001 \\
Erro & 11683,572 & 3141 & 3,720 & & \\
Correlação Total & 11728,616 & 3142 & & & \\
\hline DISCIPLINA & 361,377 & 1 & 361,377 & 99,856 & 0,000 \\
Erro & 11367,240 & 3141 & 3,619 & & \\
Correlação Total & 11728,616 & 3142 & & & \\
\hline PROFESSOR & 143,090 & 1 & 143,090 & 38,794 & 0,000 \\
Erro & 11585,526 & 3141 & 3,688 & & \\
Correlação Total & 11728,616 & 3142 & & & \\
\hline
\end{tabular}

Para os alunos os resultados indicam que aqueles que são classificados como seqüenciais obtiveram médias mais altas. As disciplinas globais favoreceram um melhor desempenho dos alunos, assim como os professores globais.

A análise multivariada levou às mesmas constatações, com exceção da variável estilo do professor, que, em conjunto com as outras variáveis, não se mostrou significativa. Foram observadas, ainda, interações significativas de $2^{\mathrm{a}}$ ordem entre as variáveis: estilo do aluno e estilo do professor; estilo da disciplina e estilo do professor. A interação de $3^{\mathrm{a}}$ ordem demonstra que a combinação dos estilos dos três fatores impacta nas médias dos alunos, como visto na tabela 15 :

Tabela 15 - ANOVA multifatorial para dimensão seqüencial/global (variável dependente: nota)

\begin{tabular}{l|r|r|r|r|r}
\hline \multicolumn{1}{c|}{ Fonte } & $\begin{array}{c}\text { Soma dos } \\
\text { Quadrados }\end{array}$ & g.l. & \multicolumn{1}{c|}{ Médio } & \multicolumn{1}{c|}{ F } & \multicolumn{1}{c}{ p } \\
\hline ALUNO & 27,166 & 1 & 27,166 & 7,615 & 0,006 \\
DISCIPLINA & 295,522 & 1 & 295,522 & 82,839 & 0,000 \\
PROFESSOR & 1,323 & 1 & 1,323 & 0,371 & 0,543 \\
ALUNO*DISC. & $8,801 E-02$ & 1 & $8,801 \mathrm{E}-02$ & 0,025 & 0,875 \\
ALUNO*PROF. & 24,563 & 1 & 24,563 & 6,885 & 0,009 \\
DISC.*PROF. & 49,019 & 1 & 49,019 & 13,741 & 0,000 \\
ALUNO*DISC.*PROF. & 24,208 & 1 & 24,208 & 6,786 & 0,009 \\
Erro & 11183,835 & 3135 & 3,567 & & \\
Correlação Total & 11728,616 & 3142 & & & \\
\hline
\end{tabular}

A interação entre aluno e professor indica que quando o estilo é seqüencial para ambos, têm-se médias significativamente superiores às obtidas em outra combinação. No que 
diz respeito à interação entre o estilo da disciplina e o estilo do professor, verifica-se que a maior média é obtida quando a disciplina é global e o professor é seqüencial.

A combinação de estilos seqüencial para aluno e professor e estilo global para disciplina é a que mais impacta positivamente o desempenho dos alunos. Com essa combinação, os alunos obtiveram média de 8,393, afastando novamente a suposição de que seria melhor que os três elementos tivessem os mesmos estilos de aprendizagem. Contrariamente, aluno com estilo global, disciplina e professor com estilo seqüencial é a combinação que mais impacta o desempenho de forma negativa, resultando uma média de 6,346. Todas essas informações estão expressas na tabela 16.

Tabela 16 - Combinações possíveis para seqüencial/global

\begin{tabular}{lll|c}
\hline ALUNO & \multicolumn{1}{l|}{ DISCIPLINA } & PROFESSOR & Média \\
\hline Global & global & Global & 7,578 \\
& & Seqüencial & 7,476 \\
\cline { 2 - 4 } & \multirow{2}{*}{ seqüencial } & Global & 6,696 \\
& & Seqüencial & 6,345 \\
\hline \multirow{2}{*}{ Seqüencial } & global & Global & 7,318 \\
& & Seqüencial & 8,393 \\
\cline { 2 - 4 } & \multirow{2}{*}{ seqüencial } & Global & 6,987 \\
& & Seqüencial & 6,641 \\
\hline
\end{tabular}

\subsection{Análise geral dos resultados e estratégias de ensino e aprendizagem}

Nesse ponto tenta-se demonstrar, com o apoio da literatura e com base nos resultados obtidos na pesquisa empírica, como se pode ajustar um ambiente de aprendizagem de modo a explorar todo ou a maior parte do potencial de cada estudante, como desenvolver habilidades de estudo, individuais ou em grupos, e como provocar mudanças em sala de aula com o foco no aluno (estratégias de ensino e aprendizagem). Toda a análise baseia-se na teoria dos estilos de aprendizagem e objetiva reforçar a idéia de que o conhecimento destes pode favorecer o ensino de Contabilidade. 
Inicialmente é preciso avaliar as diferenças encontradas entre as médias dos alunos devido aos diversos estilos, a fim de descobrir se tais diferenças são capazes de justificar ações em favor de mudanças no ambiente educacional. Segundo Hair et al. (2005, p. 39), procedendo dessa maneira, em termos acadêmicos, a pesquisa está se concentrando não apenas em resultados estatisticamente significantes, mas também, em suas implicações substantivas e teóricas, as quais são, muitas vezes, extraídas de sua significância prática.

Para tanto, elaborou-se uma tabela que resume as combinações de estilos para alunos, professores e disciplinas que geraram as maiores e menores médias e as diferenças entre elas:

Tabela 17 - Combinações de maiores e menores médias

\begin{tabular}{|c|c|c|c|c|c|c|}
\hline Dimensão & Aluno & Professor & Disciplina & Maior Média & Menor Média & Diferença \\
\hline \multirow[t]{2}{*}{ Ativo/Reflexivo } & reflexivo & reflexivo & ativa & 6,97 & & \\
\hline & reflexivo & ativo & ativa & & 6,39 & 0,58 \\
\hline \multirow[t]{2}{*}{ Sensorial/Intuitivo } & intuitivo & intuitivo & intuitiva & 7,92 & & \\
\hline & intuitivo & intuitivo & sensorial & & 6,29 & 1,63 \\
\hline \multirow[t]{2}{*}{ Visual/Verbal } & verbal & visual & verbal & 7,19 & & \\
\hline & visual & verbal & verbal & & 6,56 & 0,63 \\
\hline \multirow[t]{2}{*}{ Seqüencial/Global } & seqüencial & seqüencial & global & 8,39 & & \\
\hline & global & seqüencial & seqüencial & & 6,35 & 2,04 \\
\hline
\end{tabular}

Observa-se, na tabela 17, duas diferenças mais significativas e outras duas não tanto, o que indica que determinados estilos, dentro do curso de Contabilidade da FEA-RP, influenciam mais que outros, tanto de forma positiva como negativa.

É importante relembrar que a nota não representa aprendizagem, mas é um critério estabelecido pela instituição de ensino que vai definir se o aluno está apto para seguir em frente no curso ou não. Fracassos em determinadas disciplinas e momentos do curso acontecem e podem desestimular a continuidade deste ou até mesmo interferir na sua qualidade. Desse modo, acredita-se que ações poderiam ser implementadas para estimular os estilos menos favorecidos e continuar mantendo o bom desempenho dos outros. 
Sabe-se, também, que 0,5 ponto abaixo do mínimo exigido como média satisfatória pela instituição para conclusão de uma disciplina, já é suficiente para obrigar o aluno a passar por uma reavaliação ou até mesmo cursar a mesma disciplina novamente, o que é ruim, tanto para o aluno, quanto para o curso, a instituição e o mercado de trabalho que está à espera de um profissional.

Para complementar a análise dos resultados obtidos com essa pesquisa na FEA-RP, foi perguntado à chefia do Departamento de Contabilidade, qual seria o perfil do curso de graduação em Contabilidade, dentro das dimensões do Modelo de Felder-Silverman (1988). Esse questionamento foi feito com o intuito de avaliar se os perfis de alunos, professores e disciplinas, identificados pela pesquisa, coincidem com o perfil geral praticado e desejado atualmente no curso.

A resposta mostrou que o perfil atual do curso de graduação em Contabilidade da FEA-RP é: ativo, sensorial, verbal e seqüencial.

Esse perfil não coincide, exatamente, com o perfil dominante em nenhum dos três elementos, sendo mais próximo do perfil dos alunos e das disciplinas. Também não coincide com as combinações que proporcionaram médias significativamente maiores, como pode ser observado no quadro 12 a seguir:

\begin{tabular}{|c|c|c|c|c|}
\hline ELEMENTOS & \multicolumn{4}{|c|}{ ESTILOS } \\
\hline Alunos & ativo & sensorial & visual & seqüencial \\
\hline Professores & reflexivo & intuitivo & visual & seqüencial \\
\hline Disciplinas & reflexiva & sensorial & verbal & seqüencial \\
\hline Curso & ativo & sensorial & verbal & seqüencial \\
\hline Combinação para aluno & reflexivo & intuitivo & verbal & seqüencial \\
\hline Combinação para professor & reflexivo & intuitivo & visual & seqüencial \\
\hline "Combinação para disciplina & ativa & intuitiva & verbal & global \\
\hline
\end{tabular}

Quadro 12 - Estilos predominantes em cada elemento e combinações de maior média

Portanto, não há como afirmar que o perfil do curso determina precisamente o perfil dos alunos, professores e disciplinas, pois o primeiro está mais ligado a algo elaborado, planejado, os estilos dos alunos e professores envolvem características pessoais e particulares 
e os estilos das disciplinas podem estar mais relacionados às suas próprias exigências de conteúdo.

Considerando o exposto, passa-se a discussão ligada às ações que podem ser empreendidas em decorrência do conhecimento dos estilos de aprendizagem, tanto por parte dos professores quanto dos alunos.

\subsubsection{Recomendações práticas gerais}

Como dito anteriormente, o processo de ensino-aprendizagem envolve alguns elementos essenciais, que são: o professor (especialista), o aluno (aprendiz), o assunto (currículo, disciplina) e o ambiente (sala de aula, instituição de ensino). Todos esses elementos foram investigados nessa pesquisa.

Alguns fatores estão relacionados à figura do professor, tais como, os recursos e estratégias usados por ele, a aceitação de mudanças ou exigência de atualização e a questão da acomodação.

Quanto aos recursos e estratégias usados pelo professor, observa-se que, geralmente, os estilos de ensinar são compostos de métodos e meios didáticos com os quais ele se sente mais confortável, ou seja, a metodologia adotada é baseada no estilo do professor, sem muita preocupação com o estilo dominante dos alunos em uma sala de aula.

No que diz respeito à aceitação de mudanças ou exigência de atualização, é preciso certo cuidado, pois, se o professor mudar subitamente seus métodos, ele tenderá a realizar seu trabalho de maneira desestimulante, podendo provocar resultados desastrosos no aprendizado dos alunos. As mudanças devem ser frutos da percepção e necessidades do professor durante o processo de ensino-aprendizagem. 
Com relação ao fator acomodação, verifica-se que a dedicação normalmente requerida do professor é considerada um dos fatores que o levam a se acomodar em seus métodos de ensino, já que o educador tem que desenvolver uma série de outras atividades quando não está em sala de aula: pesquisar, estudar, participar de congressos, conferências etc.

Essa breve discussão pretende evidenciar que todo professor manifesta seu estilo nas atividades de ensino e que tal estilo pode não ser compatível com a disciplina que está sendo ministrada e com determinada turma de estudantes, como os resultados dessa pesquisa também apontaram. Além disso, como afirma Belhot (1997, p. 30), diversos estilos podem ser adotados e combinados para se obter melhores resultados de ensino e aprendizagem, o que também ficou evidenciado por esse trabalho.

Felder \& Silverman (1988, p. 680) apresentam algumas propostas para ajustar as técnicas de ensino a todos os estilos de aprendizagem, dentre as quais estão as seguintes:

- Motive para o aprendizado. Tanto quanto possível, relacione o material que está sendo apresentado com o que já foi visto anteriormente, ou com o que está por vir na mesma disciplina; integre com outras disciplinas e à experiência pessoal dos alunos (global);

- Forneça um equilíbrio entre informação concreta - fatos, dados, experiências reais ou hipotéticas e seus resultados - (sensorial) e conceitos abstratos - princípios, teorias, modelos matemáticos - (intuitivo);

- Equilibre o material que enfatiza os métodos de solução de problemas (sensorial/ ativo) com o material que enfatiza o entendimento fundamental, básico (intuitivo/ reflexivo);

- Siga o método científico na apresentação de material teórico. Forneça exemplos concretos do fenômeno descrito pela teoria (sensorial) e, então, desenvolva a teoria ou formule o modelo (intuitivo/seqüencial); mostre como o modelo pode ser validado, 
analise as conseqüências (seqüencial) e apresente aplicações práticas (sensorial/seqüencial);

- Use figuras, esquemas, gráficos e simples esboços antes, durante e depois da apresentação de material verbal; mostre filmes (sensorial/visual) e faça demonstrações (sensorial/visual) que envolvam a participação ativa, se possível (ativo);

- Não use todo o tempo da aula palestrando ou escrevendo no quadro. Dê intervalos breves para que os alunos reflitam sobre o assunto (reflexivo);

- Possibilite aos alunos a oportunidade de fazer alguma coisa ativa, além de transcrever notas de aula (ativo);

- Faça alguns exercícios para sedimentar a prática dos métodos básicos que estão sendo ensinados (sensorial/ativo/seqüencial). Forneça, também, exercícios abertos que exijam análise e síntese (intuitivo/reflexivo/global);

- Estimule as soluções criativas, não convencionais (intuitivo/global);

- Converse com os estudantes sobre os estilos de aprendizagem, aconselhando e nas aulas. Os estudantes são tranqüilizados para encontrar suas dificuldades acadêmicas que podem não ser todas decorrentes de inadequações pessoais. Explicar aos aprendizes sensoriais, ativos ou globais como eles podem aprender mais eficientemente, pode ser uma etapa importante para ajudá-los a reformular suas experiências de aprendizagem, de modo que possam ser bem sucedidas para todos os tipos.

Como foi visto no decorrer desse estudo e de acordo com o que acabou de ser exposto, existem várias metodologias à disposição dos educadores, mas que nem sempre são empregadas. Por isso, sugere-se a utilização de metodologias diversificadas, inovadoras e flexíveis que podem favorecer bastante o ensino de Contabilidade. 
Os alunos, por sua vez, sentem-se desconfortáveis com determinadas disciplinas e metodologias empregadas pelos docentes. Isso pode ser decorrente da incompatibilidade entre os estilos de aprendizagem. Daí, segundo Felder \& Soloman (s/d) surge a necessidade de desenvolver algumas estratégias.

Assistir aulas sem qualquer atividade participativa, somente tomando notas, é difícil tanto para os aprendizes ativos quanto reflexivos, mas, particularmente, para os ativos.

Um aprendiz ativo em uma aula em que se concede pouco ou nenhum tempo para discussão ou para atividades de resolução de problemas, pode compensar as deficiências quando estudar. Estudar com um grupo no qual os membros, um por vez, explicam diferentes tópicos aos outros e trabalhar com os outros alunos para antever o que lhe será perguntado no próximo teste, planejando como responderá, seriam algumas estratégias. O aprendiz ativo certamente reterá melhor a informação se encontrar maneiras de utilizá-la de forma prática.

O aprendiz reflexivo não pode ficar apenas na leitura ou memorização do material. É preciso fazer paradas periódicas para revisar o que leu e para pensar em possíveis questões ou aplicações. O reflexivo pode descobrir que é útil escrever com suas próprias palavras, pequenos resumos das leituras ou anotações de aula. Isso toma algum tempo, mas lhe permitirá reter o material de maneira mais efetiva.

Os aprendizes sensoriais gostam de aprender fatos, de resolver problemas com métodos estabelecidos, sem complicações e surpresas. Já os intuitivos preferem descobrir possibilidades e relações, gostam de novidade e se aborrecem com a repetição. Os sensoriais ressentem-se mais do que os intuitivos quando são testados sobre um material que não foi coberto explicitamente na aula.

Para ser eficiente como aprendiz e solucionador de problemas, é preciso estar apto para agir das duas maneiras. Ao enfatizar demasiadamente a intuição, o aluno pode deixar escapar detalhes importantes ou cometer erros por distração nos cálculos ou nos trabalhos 
práticos; ao enfatizar demasiadamente o lado sensorial, o aluno pode confiar demais na memorização e nos métodos tradicionais e não se concentrar o suficiente para o entendimento e o raciocínio inovador.

Os sensoriais compreendem e retêm melhor a informação se percebem como ela se relaciona com o mundo real. Se o aprendiz sensorial está em uma aula onde o material é mais abstrato e teórico, poderá ter dificuldades. Deve, então, pedir ao professor exemplos específicos dos conceitos e procedimentos e descobrir como estes se aplicam na prática. Se o professor não fornecer exemplos suficientes, deve tentar encontrar alguns nos livros-texto ou em outras referências, ou ainda, através de discussões com amigos ou colegas de classe.

Conforme Felder \& Soloman (s/d), na faculdade, grande parte das aulas expositivas é dirigida aos intuitivos. No entanto, se o aprendiz fortemente intuitivo está assistindo uma aula que trata principalmente com memorização e aplicação rotineira de fórmulas, ele pode se aborrecer. Será preciso pedir ao professor interpretações ou teorias que liguem os fatos, ou tentar encontrar as conexões ele mesmo. Esse estilo pode, também, estar propenso a cometer erros nas provas por ser impaciente com detalhes e não gostar de repetição (como conferir os problemas resolvidos). Uma estratégia seria dedicar tempo suficiente para ler a questão inteira antes de começar a responder e conferir os resultados.

Aprendizes visuais relembram melhor o que viram - figuras, diagramas, fluxogramas, filmes e demonstrações. Aprendizes verbais conseguem tirar maior proveito das palavras explanações escritas ou faladas. O que se sabe é que todos aprendem melhor quando a informação é apresentada visual e verbalmente.

Geralmente, os estudantes ouvem as preleções e lêem o material escrito na lousa, nos livros-texto e nas notas de aula. Os bons aprendizes são capazes de processar a informação apresentada visual ou verbalmente. 
Um aprendiz visual deve tentar encontrar esboços, esquemas, fotos, fluxogramas ou qualquer outra representação visual do material da disciplina que seja predominantemente verbal; consultar livros de referências e verificar se existem vídeos ou DVD's relativos ao material da disciplina; preparar um mapa conceitual identificando os tópicos principais e colocando-os nos blocos; traçar linhas ligando os conceitos e mostrando as conexões; utilizar marcadores de texto e codificar com cores as suas anotações, atribuindo a mesma cor aos itens que se relacionem com o mesmo tópico.

O aprendiz verbal deve escrever sumários ou resumos do material da disciplina usando suas próprias palavras. Trabalhar em grupos pode ser particularmente efetivo, pois consegue entender melhor o material ouvindo exposições dos seus colegas de classe e aprende ainda mais quando dá as explicações.

Os aprendizes sequienciais tendem a aprender de forma linear, em etapas logicamente seqüenciadas. Os seqüenciais podem não entender completamente o material, mas eles sempre podem fazer alguma coisa com ele (como resolver os problemas de casa ou passar na prova) desde que as partes que assimilaram estejam conectadas logicamente.

Os aprendizes globais tendem a aprender em grandes saltos, assimilando o material quase aleatoriamente, sem ver as conexões, para, então, repentinamente compreender tudo. Os aprendizes fortemente globais, que precisam de habilidades de raciocínio seqüencial, por outro lado, podem ter sérias dificuldades até que consigam o quadro geral. Mesmo depois que conseguem, eles podem ser imprecisos quanto aos detalhes da matéria, enquanto que os seqüenciais, mesmo conhecendo bastante sobre aspectos específicos de uma matéria, podem ter dificuldades para relacioná-los a diferentes aspectos da mesma matéria ou matérias diferentes.

Nas instituições, a maioria das disciplinas é lecionada de maneira seqüencial. No entanto, um aprendiz seqüencial que tem um professor que salta de um tópico para outro ou 
deixa de cobrir algumas etapas, poderá ter dificuldades para acompanhar e relembrar depois. Nesse caso, deve pedir ao professor para dar detalhes adicionais sobre as etapas que deixou de lado ou procurar os detalhes ele mesmo, consultando referências. Quando estiver estudando, dedicar algum tempo para resumir o material e colocá-lo em ordem lógica. Poderá, também, tentar fortalecer habilidades de raciocínio global relacionando cada novo tópico com coisas que já conhece. Quanto mais fizer isso, mais profundo será o conhecimento sobre a matéria.

No curso de Contabilidade da FEA-RP, os alunos seqüenciais com professores seqüenciais foram os que obtiveram a maior média de desempenho.

Para um aprendiz global, o reconhecimento de que não é lento nem ignorante, mas simplesmente, age de maneira diferente dos colegas de classe, ajuda muito. Entretanto, algumas sugestões podem auxiliá-lo a construir o quadro geral mais rapidamente.

Antes de começar a estudar a primeira parte do capítulo de um texto, o aprendiz com esse estilo deve ler o capítulo inteiro para ter uma visão geral. Fazer isso vai tomar tempo, inicialmente, mas poupará repetidos retornos a tópicos específicos mais tarde. Ao invés de gastar um pouco de tempo em cada assunto, cada dia, poderá concluir que é mais produtivo absorver-se com cada assunto durante períodos longos.

Pode, ainda, tentar relacionar o assunto com coisas que conhece, pedindo ajuda ao professor para ver as conexões, ou consultando referências. Acima de tudo, não deve perder a confiança em si mesmo, pois, no tempo certo, compreenderá o novo material de uma vez. Tendo compreendido como ele se relaciona com outros tópicos e áreas, estará apto para aplicá-lo de formas que os seqüenciais nem julgariam ser possíveis.

Enfim, têm-se diversas estratégias a serem desenvolvidas e aplicadas tanto pelos alunos quanto pelos professores, para que possam melhorar o relacionamento e o desempenho das funções de ambos.

Após essas sugestões, passa-se, agora, às observações conclusivas. 


\section{CONSIDERAÇÕES FINAIS}

Com base na pesquisa desenvolvida é possível constatar que os objetivos estabelecidos foram alcançados. A questão que deu origem ao problema da pesquisa foi respondida, dentro da delimitação temática proposta.

Pelo referencial teórico elaborado, conclui-se que o trabalho foi direcionado a um tema de relevância que vem sendo estudado durante décadas por diversos pesquisadores, tanto das áreas de educação, psicologia e engenharia, como também, da área de Contabilidade.

O fato de explorar um pouco as teorias de aprendizagem e de estilos cognitivos forneceu embasamento para a discussão posterior sobre os estilos de aprendizagem e os modelos e instrumentos de avaliação dos estilos de aprendizagem. A abordagem sobre o processo de ensino-aprendizagem e sobre os objetivos educacionais trouxe informações relevantes para argumentar a respeito dos pilares do ensino - professor, aluno e disciplina - e suas atribuições.

Os aspectos relativos, mais especificamente, ao ensino de Contabilidade, tais como, o histórico da Contabilidade e da instituição pesquisada, as características de conteúdos curriculares do curso superior de Contabilidade, as competências, habilidades, metodologias didáticas e questões de qualidade, deram subsídios para as reflexões, visando o objetivo principal desse trabalho que foi avaliar o impacto dos estilos de aprendizagem no desempenho acadêmico dos alunos de Contabilidade da FEA-RP.

É importante relembrar que os cursos superiores de Contabilidade merecem especial atenção, pois recebem uma procura bastante expressiva em comparação com outros cursos superiores. A área contábil, assim como outras áreas, possui características particulares, deve formar profissionais capacitados para atender a demanda da sociedade e preocupar-se com o aperfeiçoamento contínuo. 
A estrutura metodológica proposta e as técnicas estatísticas empregadas possibilitaram confirmar ou não as hipóteses levantadas, por meio dos resultados obtidos e das análises efetuadas.

As três hipóteses iniciais foram formuladas a partir da necessidade de conhecer se o desempenho acadêmico dos alunos sofre o impacto dos estilos de aprendizagem dos elementos principais do ensino de Contabilidade. Essas três hipóteses foram rejeitadas, mas merecem alguns comentários.

Como visto, o ILS de Felder-Soloman contém quatro dimensões com duas categorias de estilos possíveis. Por esse motivo, foi preciso testar as hipóteses para cada dimensão.

A primeira hipótese, que envolveu estilo do aluno e desempenho, foi rejeitada para três dimensões e deixou de ser rejeitada para a dimensão ativo/reflexivo, o que significa que o desempenho acadêmico se alterou conforme se alteraram os estilos de aprendizagem presentes nos alunos e manteve-se constante apenas na dimensão ativo/reflexivo.

$\mathrm{Na}$ segunda hipótese testou-se a influência dos estilos dos professores sobre o desempenho. Essa hipótese foi rejeitada para as dimensões ativo/reflexivo e seqüencial/global, e deixou de ser rejeitada para as dimensões sensorial/intuitivo e visual/global. Dessa forma, constata-se que em duas dimensões o desempenho sofreu impacto de acordo com os estilos e nas outras duas, permaneceu inalterado.

A terceira hipótese relacionou o desempenho acadêmico aos estilos das disciplinas e foi rejeitada nas dimensões sensorial/intuitivo e seqüencial/global, mostrando o impacto dos estilos das disciplinas sobre tais dimensões, e deixou de ser rejeitada nas dimensões ativo/reflexivo e visual/verbal.

As quatro hipóteses seguintes envolveram as combinações possíveis entre esses elementos, a fim de identificar quais estariam causando impacto. Dessas quatro, somente uma deixou de ser rejeitada. 
A combinação: estilos de aprendizagem dos alunos e estilos de aprendizagem dos professores deu origem à quarta hipótese, que, ao ser testada, foi rejeitada para a dimensão seqüencial/global, evidenciando influência no desempenho. Para as outras três dimensões, essa hipótese deixou de ser rejeitada, pois o desempenho manteve-se constante.

A quinta hipótese deixou de ser rejeitada em todas as dimensões. Essa hipótese tratou da combinação entre os estilos dos alunos e os estilos das disciplinas e foi confirmada pelos resultados que indicaram que não existe diferença no desempenho acadêmico, independentemente da combinação de estilos de alunos e disciplinas.

Para avaliar o impacto dos estilos dos professores e das disciplinas sobre o desempenho dos alunos, elaborou-se uma sexta hipótese, que deixou de ser rejeitada apenas para a dimensão ativo/reflexivo. As combinações entre os estilos sensorial/intuitivo, visual/verbal e seqüencial/global de professores e disciplinas, impactaram as médias dos alunos e obrigaram a rejeição de mais essa hipótese.

Finalmente, foram combinados os estilos dos três elementos: alunos, professores e disciplinas, o que resultou na rejeição da sétima e última hipótese formulada para essa pesquisa. Nas dimensões ativo/reflexivo e seqüencial/global ficou demonstrado que os estilos de aprendizagem afetam o desempenho acadêmico dos alunos do curso de graduação em Contabilidade da FEA-RP, pois as médias variaram de acordo com as diversas combinações. Já nas dimensões sensorial/intuitivo e visual/verbal, o desempenho permaneceu constante, de acordo com os testes estatísticos realizados.

Dentre as contribuições do trabalho podem ser citadas: a identificação, consulta e análise de bibliografia atualizada sobre o objeto da pesquisa, em função do período de estudo; a identificação dos perfis dos estilos de aprendizagem dos alunos, professores e disciplinas do curso de graduação em Contabilidade da FEA-RP; a avaliação do impacto dos diferentes 
estilos e combinações de estilos sobre o desempenho acadêmico dos alunos; as sugestões de estratégias de ensino e aprendizagem apoiadas na literatura.

Com essa pesquisa, os envolvidos no processo de ensino-aprendizagem dentro do curso de graduação em Contabilidade da FEA-RP, têm a possibilidade de conhecer suas preferências por aprender e ensinar, verificar quais os estilos dominantes e quais combinações de estilos mais favorecem o desempenho dos alunos e, a partir daí, utilizar estratégias compatíveis com os objetivos pretendidos pelas disciplinas.

É importante destacar, também, que as pesquisas sobre o tema devem continuar trazendo outras descobertas, contribuições e progresso para a Ciência e para o processo de ensino-aprendizagem. Algumas sugestões para novas pesquisas são:

- Identificar os estilos de aprendizagem em cursos de Contabilidade de outras instituições para avaliar semelhanças e diferenças;

- Avaliar o impacto dos estilos de aprendizagem no desempenho, agrupando as disciplinas por algum critério, que poderá ser por características comuns entre disciplinas ou por objetivos educacionais, a fim de conhecer se existem diferenças de impacto entre disciplinas;

- Investigar o impacto dos estilos de aprendizagem com a utilização de algum outro critério de mensuração de desempenho que não a nota, partindo, com isso, para a questão da avaliação dos estudantes no ambiente educacional (como avaliar a aprendizagem).

Enfim, é preciso manter atenção às mudanças constantes que acontecem atualmente não só no ensino de modo geral, mas, na sociedade, e não só no Brasil, como no mundo, tentando proporcionar ou melhorar o atendimento das necessidades pessoais e profissionais. 


\section{REFERÊNCIAS BIBLIOGRÁFICAS}

BARIANI, Isabel C. Dib; SISTO, Fermino Fernandes; SANTOS, Acacia A. Angeli dos. Construção de um instrumento de avaliação de estilos cognitivos. In: SISTO, Fermino Fernandes; SBARDERLINI, Elizabeth T. Brunini; PRIMI, Ricardo (Orgs.). Contextos e questões da avaliação psicológica. São Paulo: Casa do Psicólogo, 2000. p. 173-178.

BELHOT, Renato V. Reflexões e propostas sobre o 'ensinar Engenharia' para o século XXI. 1997. 113 p. Tese (Livre Docência). Escola de Engenharia de São Carlos, Universidade de São Paulo, São Carlos, 1997.

BERTOLINI, Daniel M. Brandão. O impacto dos estilos de aprendizagem no ensino contábil. 2005. 46 p. Monografia (Graduação em Contabilidade). Faculdade de Administração, Economia e Contabilidade da Universidade de São Paulo, campus Ribeirão Preto. Ribeirão Preto, 2005.

BLOOM, Benjamim S. et al. Taxonomy of Educational Objectives (Handbook I: Cognitive Domain). Nova Iorque: McKay, 1956.

Taxonomia de objetivos educacionais. Porto Alegre: Globo, 1972.

BRASIL. Lei de Diretrizes e Bases da Educação - LDB - no 9.394 de 20 de dezembro de 1996. Estabelece as diretrizes e bases da educação nacional. Disponível em: http://portal.mec.gov.br/arquivos/pdf/ldb.pdf. Acesso em 08/01/2006.

Portaria no 2.253 de 19 de outubro de 2001. Ministério da Educação. (DOU 19/10/2001, p. 18, Seção1). Portal MEC. Disponível em: http://portal.mec.gov.br/sesu/arquivos/pdf/p2253.pdf . Acesso em 30/06/2005.

Resolução CNE/CEB no 4 de 08 de dezembro de 1999. Institui as Diretrizes Curriculares Nacionais para a Educação Profissional de Nível Técnico. Disponível em: http://www.mec.gov.br/cne/pdf/CEB04991.pdf. Acesso em 23/01/2006.

Resolução CNE/CES 6, de 31 de março de 2004. Institui as Diretrizes Curriculares Nacionais para o Curso de Graduação em Ciências Contábeis, bacharelado, e dá outras providências. In: RESOLUÇÕES, 2004. Portal CNE. Disponível em: http://portal.mec.gov.br/cne/index.php?option=content\&task=view\&id=146\&Itemid=206\#20 04. Acesso em 12/04/2005.

Resolução CNE/CES 10, de 16 de dezembro de 2004. Institui as Diretrizes Curriculares Nacionais para o Curso de Graduação em Ciências Contábeis, bacharelado, e dá outras providências. In: RESOLUÇÕES, 2004. Portal CNE. Disponível em: http://portal.mec.gov.br/cne/index.php?option=content\&task=view\&id=146\&Itemid=206\#20 04. Acesso em 12/04/2005.

BUTLER, A. Learning style across content areas. In: NASSP. Student learning styles and brain behavior: programs, instrumentation, research. Reston, Virginia: National Association of Secondary School Principals, 1982. 
CAMPBELL, L.; CAMPBELL, B.; DICKINSON, D. Ensino e aprendizagem por meio das inteligências múltiplas. $2^{a}$ ed. Tradução de Magda França Lopes. Porto Alegre: Artes Médicas Sul, 2000.

CERQUEIRA, Teresa C. Siqueira. Estilos de aprendizagem em universitários. 2000. 179 p. Tese (Doutorado em Educação). Curso de Pós-Graduação em Psicologia Educacional. Faculdade de Educação da Universidade Estadual de Campinas, Campinas, 2000.

CHAVES, Lucia de F. Muller; ARIAS, Eluiza H. Leite. Elaboração de avaliações - um manual para orientação aos professores do Centro de Ciências da Saúde da UFPA. 2003. 16 p. Universidade Federal do Pará, Belém/PA, 2003.

CLAXTON, Charles S.; MURREL, Patricia H. Learning styles: implications for improving educational practices. ASHE-ERIC Higher Education Report n. 4. ISBN 0-913317-39-X. Washington/DC-USA: Association for the Study of Higher Education, 1987.

CLAXTON, Charles S.; RALSTON, Y. Learning styles: the impact on teaching and administration. Higher Education Research, Research Report, 10 (American Association for Higher Education, Washington, D.C.), 1978.

COLL, Cesar; PALACIOS, Jesus; MARCHESI, Álvaro. (Org.). Desenvolvimento psicológico e educação: psicologia da educação. Porto Alegre: Artes Médicas, 1996. v.2.

COLLINS, Julie H.; MILLIRON, Valerie C. A measure of Professional Accountant's Learning Style. Issues in Accounting Education, 193-206, 2001.

CORNACHIONE JÚNIOR, Edgard Bruno. Tecnologia da educação e cursos de Ciências Contábeis: modelos colaborativos virtuais. 2004. 383 p. Tese (Livre Docência). Faculdade de Economia, Administração e Contabilidade da Universidade de São Paulo, São Paulo, 2004.

CURRY, L. A critique of the research on learning styles. Educational Leadership, v. 48, n. 2, p. 50-56, 1990.

DeBELLO, T. C. Comparison of eleven major learning styles models: variables, appropriate populations, validity of instrumentation and the research behind them. Journal or Reading, Writing and Learning Disabilities, 6, p. 203-222, 1990.

DUFF, Angus. The role of cognitive learning styles in accounting education: developing learning competencies. Journal of Accounting Education, v. 22, n. 1, p. 29-52, 2004.

DUNN, R. Learning styles: link between individual differences and effective instruction. North Carolina Educational Leadership, v. 2, n. 1, p. 3-22, 1986.

DUNN, R.; DUNN, R. \& PRICE, G. Learning Style Inventory (LSI) for students in grades 3-12. Lawrence, Kansas: Price Systems, 1979.

EIDE, Bárbara J.; GEIGER, Marshall A.; SCHWARTZ, Bill N. The Canfield Learning Styles inventory: an assessment of its usefulness in accounting education research. Issues in Accounting Education, v. 16, n. 3, p. 341-365, 2001. 
ENTWISTLE, N. La compensación del aprendizaje en el aula. Madrid, Barcelona: MEC/Paidós, 1988.

ERICEIRA, Fernando Jorge. O estado da arte da Contabilidade no estado do Maranhão, vis-a-vis seu desenvolvimento econômico -1755 a 1900. 2003. 184 p. Dissertação (Mestrado em Controladoria e Contabilidade). Curso de Pós-Graduação em Controladoria e Contabilidade. Faculdade de Economia, Administração e Contabilidade da Universidade de São Paulo, São Paulo, 2003.

FELDER, Richard M.; SILVERMAN, Linda K. Learning and teaching styles in engineering education. Journal of Engineering Education, v. 78, n. 7, p. 674-681, 1988. Disponível em http://www.ncsu.edu/felder-public/Learning_Styles.html. Acesso em 05/08/2005.

FELDER, Richard M.; SOLOMAN, Barbara A. Index of Learning Styles Questionnaire. North Carolina State University, 1991. Disponível em http://www2.ncsu.edu/unity/lockers/users/f/felder/public/ILSdir/ILS-a.htm. Acesso em 03/01/2006.

Learning styles and strategies. North Carolina State University, (s/d). Disponível em http://www.ncsu.edu/felder-public/ILSdir/styles.htm . Acesso em 03/01/2006.

FELDER, Richard M.; HENRIQUES, Eunice R. Learning and teaching styles in foreign and second language education. Foreign Language Annals, v. 28, n. 1, p. 21-31, 1995. Disponível em http://www.ncsu.edu/felder-public/Learning_Styles.html. Acesso em 05/08/2005.

FELDER, Richard M.; FELDER, Gary N.; DIETZ, E. Jacquelin. A longitudinal study of engineering student performance and retention: V comparisons with traditionally-taught students. Journal of Engineering Education, v. 87 n. 4, p. 469-480, 1998. Disponível em http://www.ncsu.edu/felder-public/Learning_Styles.html. Acesso em 05/08/2005.

The effects of personality type on engineering student performance and attitudes. Journal of Engineering Education, v. 91, n. 1, p. 3-17, 2002. Disponível em http://www.ncsu.edu/felder-public/Learning_Styles.html. Acesso em 05/08/2005.

FELDER, Richard M.; SPURLIN, Joni E. Applications, reliability, and validity of the Index of Learning Styles. Journal of Engineering Education, v. 21, n. 1, p. 103-112, 2005. Disponível em http://www.ncsu.edu/felder-public/Learning_Styles.html. Acesso em 03/01/2006.

FELDER, Richard M.; BRENT, Rebeca. Understanding student differences. Journal of Engineering Education, v. 94, n. 1, p. 57-72, 2005. Disponível em http://www.ncsu.edu/felder-public/Learning_Styles.html. Acesso em 03/01/2006.

FELDER, Richard M. Meet your students: 1. Stan and Nathan. Chemical Engineering Education, v. 23, n. 2, p. 68-69, Spring 1989. Disponível em http://www.ncsu.edu/felderpublic/Learning_Styles.html. Acesso em 05/08/2005. 
Meet your students: 2. Susan and Glenda. Chemical Engineering Education, v. 24 n. 1, p. 7-8, Winter 1990a. Disponível em http://www.ncsu.edu/felderpublic/Learning_Styles.html. Acesso em 05/08/2005.

Meet your students: 3. Michelle, Rob, and Art. Chemical Engineering Education, v. 24, n. 3, p. 130-131, Summer 1990b. Disponível em http://www.ncsu.edu/felderpublic/Learning_Styles.html. Acesso em 05/08/2005.

Meet your students: 4. Jill and Perry. Chemical Engineering Education, v. 25, n. 4, p. 196-197, Fall 1991. Disponível em http://www.ncsu.edu/felderpublic/Learning_Styles.html. Acesso em 05/08/2005.

Reaching the second tier: learning and teaching styles in College Science Education. J. College Science Teaching, v. 23, n. 5, p. 286-290, 1993. Disponível em http://www.ncsu.edu/felder-public/Learning_Styles.html. Acesso em 05/08/2005.

Meet your students: 5. Edward and Irving. Chemical Engineering Education, v. 28, n. 1, p. 36-37, Winter 1994. Disponível em http://www.ncsu.edu/felderpublic/Learning_Styles.html. Acesso em 05/08/2005.

Meet your students: 6. Tony and Frank. Chemical Engineering Education, v. 29, n. 4, p. 244-245, Fall 1995a. Disponível em http://www.ncsu.edu/felderpublic/Learning_Styles.html. Acesso em 05/08/2005.

A longitudinal study of engineering student performance and retention: IV instructional methods and student responses to them. Journal of Engineering Education, v. 84, n. 4, p. 361-367, 1995b. Disponível em http://www.ncsu.edu/felderpublic/Learning_Styles.html. Acesso em 05/08/2005.

. Matters of style. ASEE Prism, v. 6, n. 4, p. 18-23, December 1996. Disponível em http://www.ncsu.edu/felder-public/Learning_Styles.html. Acesso em 05/08/2005.

FIERRO, Alfredo. Personalidade e aprendizagem no contexto escolar. In: COLL, César; PALACIOS, Jesus; MARCHESI, Álvaro (Org.). Desenvolvimento psicológico e educação: psicologia da educação. Porto Alegre: Artes Médicas, 1996. v. 2.

FREZATTI, Fábio; LEITE FILHO, Geraldo A. Análise do relacionamento entre o perfil de alunos do curso de contabilidade e o desempenho satisfatório em uma disciplina. In: ENCONTRO ANUAL DA ASSOCIAÇÃO NACIONAL DOS PROGRAMAS DE PÓSGRADUAÇÃO EM ADMINISTRAÇÃ̃O - ENANPAD, 27, 2003, Atibaia. Anais... Atibaia: ANPAD, 2003.

GIL, Antonio Carlos. Metodologia do ensino superior. $3^{\text {a }}$ ed. São Paulo, Atlas: 1997.

GIORGI, W. A. B; PIZOLATO, C. L; MORETTIN, A. A. Competências, habilidades e o ensino superior de contabilidade. In II FÓRUM NACIONAL DE PROFESSORES DE CONTABILIDADE, 7, 2001, Rio de Janeiro. Anais... Rio de Janeiro: 2001. CD-ROM.

GREGORC, A. F. Learning/teaching styles: potent forces behind them. Educational Leadership, v. 36, n. 4, p. 234-236, 1979. 
HAIR JR., Joseph F. et al. Análise multivariada de dados. Porto Alegre: Bookman, 2005.

HALL, Andréia; NEVES, Cláudia; PEREIRA, António. Grande maratona de estatística no SPSS. Aveiro (Portugal): Universidade de Aveiro, Departamento de Matemática, 2006.

Disponível em: http://www.mat.ua.pt/disciplinas/me/files/livro.pdf. Acesso em 23/10/2006.

HENDRIKSEN, Eldon.S; BREDA, Michael.F.Van. Teoria da Contabilidade. São Paulo: Atlas, 1999.

HUNT, D.E. Learning styles and student needs: an introduction to conceptual level. In: NASSP. Students' Learning Styles: diagnosing and prescribing programs. 27-38. Reston, Virginia: National Association of Secondary School Principals, 1979.

IUDÍCIBUS, Sergio de. Teoria da Contabilidade. $7^{\text {a }}$ ed. São Paulo: Atlas, 2004.

; RICARDINO FILHO, A. A. A primeira Lei das Sociedades Anônimas no Brasil. São Paulo. Revista Contabilidade e Finanças. São Paulo: FIPECAFI - FEA/USP, n. 29, p. 7-25, maio-agosto/2002.

; FRANCO, Hilario. Currículo básico do contador: orientação técnica versus orientação humanística. In: CONGRESSO INTERNACIONAL DE EDUCADORES DA ÁREA CONTÁBIL, 2, 1983, São Paulo. Anais... São Paulo, 1983.

KEEFE, J. W. Assessing student learning styles: an overview. In: NASSP. Student learning styles and brain behavior. Reston, Virginia: National Association of Secondary School Principals, 1982.

KOLB, David A. Experiential Learning: experience as the source of learning and development. New Jersey: Prentice-Hall, Englewood Cliffs, 1984.

The Learning Style Inventory: technical manual. Boston: Hay McBer, 1985.

McBer, 1993.

Self-scoring Inventory and Interpretation Booklet. Revised Edition. Boston: Hay

KRAEMER, Maria E. Pereira. Reflexões sobre o ensino da Contabilidade. Revista Brasileira de Contabilidade. Brasília: Conselho Federal de Contabilidade, n. 153, p. 65-79, maio-junho/ 2005 .

KURI, Nídia Pavan. Tipos de personalidade e estilos de aprendizagem: proposições para o ensino de Engenharia. 2004. 337 p. Tese (Doutorado em Engenharia de Produção). Curso de Pós-Graduação em Engenharia de Produção, Universidade Federal de São Carlos, São Carlos, 2004.

LAFFIN, M. Ensino da Contabilidade: componentes e desafios. In II FÓRUM NACIONAL DE PROFESSORES DE CONTABILIDADE, 7, 2001, Rio de Janeiro. Anais... Rio de Janeiro: 2001. CD-ROM.

LIVESAY, G. et al. Statistical evaluation of the Index of Learning Styles. ASEE Annual Conference and Exposition, Montreal, Quebec, Canada, 2002. Session 2430, 2002. 
LOPES, Wilma M. Guimarães. ILS - Inventário de Estilos de Aprendizagem de Felder Soloman: investigação de sua validade em estudantes universitários de Belo Horizonte. 2002. 107 p. Dissertação (Mestrado em Engenharia de Produção). Curso de Pós-Graduação em Engenharia de Produção, Universidade Federal de Santa Catarina, Florianópolis, 2002.

MANCINI, J. Estanislau Kruszynski. São Carlos: Editora Indústria e Comércio Gráfico “O Expresso", 1978.

MARION, José Carlos. O ensino da Contabilidade no Brasil. 2 ed. São Paulo: Atlas, 2001.

McKEE, Thomas E.; MOCK, Theodore J.; RUUD, T.Flemming. A comparison of Norwegian and United States accounting student's learning style preferences. Accounting Education, v. 4, n. 1, p.321-341, 1992.

MESSICK, Samuel. The matter of style: manifestations of personality in cognition, learning and teaching. Educational Psychologist, v. 29, n. 3, p. 121-136. Hove, UK, 1994.

The nature of cognitive styles: problems and promise in education practice.

Educational Psychologist, v. 19, n. 2, p. 59-74. 1984.

MIZUKAMI, Maria da Graça. Ensino: as abordagens do processo. São Paulo, EPU: 1986.

MYERS, Isabel Briggs. Introduction to type. 1st ed. Swarthmore, PA, Author: 1970.

NÉRICI, Imidio G. Metodologia do ensino, uma introdução. São Paulo, Atlas: 1981.

NOSSA, Valcemiro. Formação do corpo docente dos cursos de graduação em Contabilidade no Brasil: uma análise crítica. Caderno de Estudos. São Paulo: FIPECAFI - FEA/USP, n. 21, maio-agosto/1999. 20 p.

PELEIAS, Ivam Ricardo; BACCI, João. Pequena cronologia do desenvolvimento contábil no Brasil: os primeiros pensadores, a padronização contábil e os congressos brasileiros de contabilidade. Revista de Administração On-Line. São Paulo: FECAP, v.5, n.3, p. 39-54, julho-setembro/2004.

PEREIRA, Eritatiane Silva; LEITE FILHO, Geraldo Alemandro. A influência do marketing no perfil do profissional contábil. Revista Pensar Contábil, CRC-RJ, nº 15, 2002, p.26-30.

RAMSAY, Alan; HANLON, Dean; SMITH, David. The association between cognitive style and accounting student's preference for cooperative learning: an empirical investigation. Journal of Accounting Education, v. 18, n.3, p. 215-228, 2000.

RICHARDSON, Roberto J. et al. Pesquisa social: métodos e técnicas. São Paulo: Atlas, 1999.

RIDING, R.; CHEEMA, I. Cognitive Styles - an overview and integration. Educational Psychology, 11 (3-4), p. 193-216, 1991. 
ROCHA, Luiz Augusto de Giordano. Jogos de empresas: desenvolvimento de um modelo para aplicação no ensino de custos industriais. 1997. 65 p. Dissertação (Mestrado em Engenharia de Produção e Sistemas). Curso de Pós-Graduação em Engenharia de Produção, Universidade Federal de Santa Catarina, Florianópolis, 1997.

ROJAS, Enrique V. Caceres. Métodos aplicados a la enseñanza. Cancum, México, sep. 1995.

ROMANOWSKY, L.R.; BEUREN, I.M. Um estudo dos procedimentos metodológicos de ensino utilizados nos cursos de Ciências Contábeis. Revista Brasileira de Contabilidade. Brasília, n. 137, p.83-97, set./out. 2002.

SANTOS, Acacia A. Angeli dos; BARIANI, Isabel C. Dib; CERQUEIRA, Teresa C. Siqueira. Estilos cognitivos e estilos de aprendizagem. In: SISTO, Fermino Fernandes; OLIVEIRA, Gisele de Campos; FINI, Lucila Dihel Tolaine (Org.). Leituras de psicologia para a formação de professores. $2^{\mathrm{a}}$ ed. Petrópolis: Vozes, 2000. p. 44-57.

SANTOS, Roberto Vatan dos. Jogos de empresas aplicados ao processo de ensino e aprendizagem de Contabilidade. Revista Contabilidade e Finanças. São Paulo: FIPECAFI FEA/USP, n. 31, p. 78-95, janeiro-abril/2003.

O Método do Caso. (Rascunho para Discussão). Aula do Curso de Pós-Graduação (Mestrado) em Controladoria e Contabilidade. Faculdade de Economia, Administração e Contabilidade da Universidade de São Paulo, campus Ribeirão Preto. 2005.

SCHMECK, R.R. Inventory of learning process. In: NASSP. Student learning style and brain behavior. Reston, Virginia: National Association of Secondary School Principals, 1982.

SCHMIDT, Paulo. História do Pensamento Contábil. Porto Alegre: Bookman, 2000.

SMITH, R. M. Learning how to learn. Milton Keynes, U. K.: Open University Press, 1988.

SISTO, Fermino Fernandes; SBARDELINI, Elizabeth T. Brunini; PRIMI, Ricardo (Org.). Contextos e questões da avaliação psicológica. São Paulo: Casa do Psicólogo, 2000.

SISTO, Fermino Fernandes; OLIVEIRA, Gisele de Campos; FINI, Lucila Dihel Tolaine (Org.). Leituras de psicologia para a formação de professores. $2^{\mathrm{a}}$ ed. Petrópolis: Vozes, 2000 .

TAVARES, Marialva Rossi. Paradigmas avaliativos e o ensino de graduação. In: II FÓRUM DE GRADUAÇÃO, 2001, Montes Claros. Anais... Montes Claros, Unimontes: 2001.

WATANABE, Ippo. A profissão contábil no Brasil. Revista do Conselho Regional de Contabilidade do Estado de São Paulo, ano I, n.0. p. 5-20. dez/1996.

WOLK, Carel; NIKOLAI, Loren A. Personality types of accounting students and faculty: comparison and implications. Journal of Accounting Education, v. 15, n. 1, p. 1-17, 1997. 
ZYWNO, Malgorzata S. A contribution to validation of score meaning for Felder Soloman's Index of Learning Styles. Proceedings of the 2003 American Society for Engineering Education Annual Conference \& Exposition. 2003.

\section{Sites e links consultados:}

http://www.portaldecontabilidade.com.br. Acesso em 30/08/2005.

http://www.prod.eesc.usp.br/aprende/estilosaprendizagem.htm. Acesso em 02/09/2005.

http://www.keirsey.com/. Acesso em 20/09/2005.

www.fea.usp.br. Acesso em 20/12/2005.

www.fearp.usp.br Acesso em 20/12/2005.

www.redecontabil.com.br. Acesso em 23/12/2005.

www.portaldecontabilidade.com.br Acesso em 23/12/2005.

http://portal.mec.gov.br/sesu Acesso em 08/01/2006.

http://www.educacaosuperior.inep.gov.br/funcional/lista_cursos.asp. Acesso em 23/01/2006 e 13/06/2006.

http://www.12manage.com/methods_herrmann_whole_brain_pt.html Acesso em 26/01/2006. http://www.usd.edu/ ssanto/styles.html. Acesso em 26/02/2006.

http://www.gregorc.com/gregorc.html. Acesso em 26/02/2006.

http://library.thinkquest.org/C005704/content_lt.php3 . Acesso em 26/02/2006.

http://www.learningandteaching.info/learning/experience.htm . Acesso em 05/05/2006.

http://www.webquest.futuro.usp.br/recursos/bloom.html . Acesso em 10/05/2006.

http://ged.capes.gov.br/AgDw/silverstream/pages/frPesquisaColeta.html. Acesso em 14/06/2006.

http://www.capes.gov.br/capes/portal/conteudo/10/ProgramasReconhecidos.htm. Acesso em 14/06/2006. 
APÊNDICES 


\section{APÊNDICE A - Disciplinas da grade curricular e seus objetivos}

\begin{tabular}{|c|c|}
\hline DISCIPLINAS OBRIGATÓRIAS & OBJETIVOS \\
\hline 1. Análise das Demonstrações Contábeis & $\begin{array}{l}\text { Uma parte do curso volta-se ao ensino dos critérios e instrumentos } \\
\text { de análise, sendo a outra parte dedicada a promover análise de } \\
\text { balanços de diferentes tipos e naturezas de empresa. }\end{array}$ \\
\hline 2. Análise de Custos & $\begin{array}{l}\text { Entender os sistemas de custeamento e os métodos de custeio como } \\
\text { ferramentas de apoio para o processo de tomada de decisões, } \\
\text { planejamento e controle. }\end{array}$ \\
\hline 3. Análise de Sistemas Contábeis & $\begin{array}{l}\text { Permitir a compreensão dos principais aspectos da utilização da } \\
\text { informação contábil e o processo de geração de informações, tanto } \\
\text { na contabilidade como na controladoria. Estudar os processos de } \\
\text { geração de informações e suas inter-relações com processos de } \\
\text { negócio, com ênfase na integração conceitual de sistemas de } \\
\text { informação. }\end{array}$ \\
\hline 4. Contabilidade Avançada & $\begin{array}{l}\text { O objetivo principal é o aprendizado das técnicas de elaboração de } \\
\text { demonstrações contábeis consolidadas e em moeda constante. }\end{array}$ \\
\hline 5. Contabilidade de Custos & $\begin{array}{l}\text { Apresentar os principais conceitos contábeis aplicados à } \\
\text { contabilidade de custos e à utilização destes para fins de avaliação } \\
\text { de estoques. }\end{array}$ \\
\hline 6. Contabilidade Governamental & $\begin{array}{l}\text { Tornar o orçamento público acessível e possibilitar o domínio da } \\
\text { sistemática que envolve o controle orçamentário e financeiro da } \\
\text { administração direta tendo em vista, principalmente, o equilíbrio } \\
\text { orçamentário (recursos-despesa), transmitindo as práticas contábeis } \\
\text { adotadas, limitações e alcance das informações consubstanciadas } \\
\text { nos demonstrativos específicos obtidos. }\end{array}$ \\
\hline 7. Contabilidade Intermediária & $\begin{array}{l}\text { Consolidar os conhecimentos de Contabilidade básica e abordar } \\
\text { assuntos específicos que requeiram tratamento especial. }\end{array}$ \\
\hline 8. Contabilidade Introdutória I & $\begin{array}{l}\text { Introduzir os conhecimentos de Contabilidade com ênfase nos } \\
\text { lançamentos e interpretação dos eventos contábeis; ensinar a lógica } \\
\text { contábil bem como apresentar as primeiras demonstrações } \\
\text { contábeis: Balanço Patrimonial e Demonstração do Resultado do } \\
\text { Exercício. }\end{array}$ \\
\hline 9. Contabilidade Introdutória II & $\begin{array}{l}\text { Fixar o conhecimento sobre o mecanismo contábil (escrituração, } \\
\text { apuração de resultado e elaboração do Balanço Patrimonial e } \\
\text { Demonstração do Resultado do Exercício) bem como ensinar } \\
\text { escrituração de conceitos específicos e introduzir as demonstrações } \\
\text { contábeis DOAR e DFC. }\end{array}$ \\
\hline 10. Contabilidade Tributária I & $\begin{array}{l}\text { Propiciar conhecimentos básicos das normas tributárias, } \\
\text { especialmente as relacionadas com atividades empresariais, } \\
\text { destacando os principais instrumentos da administração fiscal. }\end{array}$ \\
\hline 11. Contabilidade Tributária II & $\begin{array}{l}\text { Levar o aluno ao conhecimento e aplicação dos principais tributos } \\
\text { diretos e sua relação com a Contabilidade e a Controladoria, de } \\
\text { forma a capacitá-lo à execução, análise e interpretação do processo } \\
\text { de tributação das empresas. }\end{array}$ \\
\hline 12. Teoria da Contabilidade & $\begin{array}{l}\text { Fornecer ao aluno uma visão da evolução histórica da contabilidade } \\
\text { e da situação do pensamento atual sobre Princípios Contábeis, } \\
\text { quanto a seu enunciado, suas razões e embasamento. }\end{array}$ \\
\hline $\begin{array}{l}\text { 13. Fundamentos para Análise de } \\
\text { Sistemas }\end{array}$ & $\begin{array}{l}\text { Estudar os fundamentos da análise de sistemas visando a sua } \\
\text { aplicação na análise dos processos empresariais e no projeto dos } \\
\text { sistemas de informação dentro do conceito de recurso estratégico } \\
\text { para as organizações e considerando a visão da controladoria. }\end{array}$ \\
\hline 14. Informática Aplicada & $\begin{array}{l}\text { Ensinar aos alunos de Ciências Contábeis os conceitos básicos de } \\
\text { Hardware, Software, bem como o uso de planilha eletrônica e } \\
\text { sistemas para escrita contábil para suporte a gestão. }\end{array}$ \\
\hline $\begin{array}{l}\text { 15. Introdução à Probabilidade e à } \\
\text { Estatística I }\end{array}$ & $\begin{array}{l}\text { Capacitar os alunos a descrever e interpretar um fenômeno através } \\
\text { de seus dados, fornecendo-lhes, além disso, os conceitos } \\
\text { probabilísticos necessários à sua formação estatística futura. } \\
\text { (continua...) }\end{array}$ \\
\hline
\end{tabular}




\begin{tabular}{|c|c|}
\hline $\begin{array}{l}\text { (continuação....) } \\
\text { DISCIPLINAS OBRIGATÓRIAS }\end{array}$ & OBJETIVOS \\
\hline $\begin{array}{l}\text { 16. Introdução à Probabilidade e à } \\
\text { Estatística II }\end{array}$ & $\begin{array}{l}\text { Capacitar os alunos a planejar, realizar e concluir uma pesquisa } \\
\text { utilizando os conceitos básicos de inferência estatística. }\end{array}$ \\
\hline $\begin{array}{l}\text { 17. Complementos de Matemática para } \\
\text { Contabilidade }\end{array}$ & $\begin{array}{l}\text { O curso objetiva basicamente habilitar o aluno ao uso de } \\
\text { ferramental matemático a ser utilizado nos campos da controladoria, } \\
\text { contabilidade e finanças. }\end{array}$ \\
\hline 18. Auditoria e Perícia & $\begin{array}{l}\text { Fornecer aos alunos uma ampla visão da filosofia, dos conceitos e } \\
\text { da metodologia de trabalho em Auditoria e Perícia, quer como } \\
\text { campo de atuação profissional dos bacharéis em Ciências } \\
\text { Contábeis, quer como área de conhecimento técnico das quais se } \\
\text { requer um mínimo de formação técnica para o exercício da } \\
\text { atividade de auditoria e perícia. }\end{array}$ \\
\hline 19. Comunicação Oral e Escrita & $\begin{array}{l}\text { Levar o aluno a reconhecer as diferenças entre comunicação oral e } \\
\text { comunicação escrita. Capacitar o aluno a estabelecer comunicação } \\
\text { eficaz pela correção de suas falhas. }\end{array}$ \\
\hline 20. Direito Empresarial & (não há declaração de objetivos para essa disciplina) \\
\hline $\begin{array}{l}\text { 21. Economia Brasileira para } \\
\text { Administradores }\end{array}$ & $\begin{array}{l}\text { Ajudar os alunos a aumentar seu nível de compreensão da realidade } \\
\text { econômica brasileira. }\end{array}$ \\
\hline 22. Estratégia Financeira & $\begin{array}{l}\text { Apresentar a base conceitual necessária e a análise das grandes } \\
\text { decisões financeiras das empresas sob a ótica da maximização da } \\
\text { riqueza dos seus acionistas. }\end{array}$ \\
\hline 23. Introdução à Sociologia & $\begin{array}{l}\text { Introduzir os alunos no universo das questões mais centrais } \\
\text { estudadas pela Sociologia, tais como a constituição da sociedade } \\
\text { capitalista, suas etapas de desenvolvimento, as transformações } \\
\text { ocorridas na estrutura de classe e na organização do trabalho. }\end{array}$ \\
\hline 24. Legislação Social & $\begin{array}{l}\text { Promover a atualização necessária face às transformações do } \\
\text { Direito do Trabalho na atual conjuntura. }\end{array}$ \\
\hline 25. Matemática Financeira & $\begin{array}{l}\text { Apresentar a base conceitual necessária e a análise do conceito do } \\
\text { "valor do dinheiro no tempo". Espera-se tornar o aluno apto a } \\
\text { resolver, de forma consciente, e, não automática, problemas de } \\
\text { natureza financeira, através do uso de formulações matemáticas e } \\
\text { calculadoras financeiras. }\end{array}$ \\
\hline 26. Mercado Financeiro I & $\begin{array}{l}\text { Apresentar as características gerais: da estrutura do Sistema } \\
\text { Financeiro Nacional (SFN), com enfoque nas Instituições } \\
\text { Financeiras; dos ativos financeiros negociados no país e as técnicas } \\
\text { de análise do ponto de vista do investidor. Estimular a análise } \\
\text { crítica dos fatos e acontecimentos econômicos e suas relações com } \\
\text { o mercado financeiro e a gestão empresarial. }\end{array}$ \\
\hline $\begin{array}{l}\text { 27. Planejamento Estratégico e } \\
\text { Orçamento Empresarial }\end{array}$ & $\begin{array}{l}\text { Conduzir a identificação dos conceitos e princípios fundamentais de } \\
\text { orçamento empresarial, relacionando o planejamento e o controle } \\
\text { financeiro ou de resultados, com as funções de Administração e } \\
\text { Contabilidade. }\end{array}$ \\
\hline 28. Português Instrumental & $\begin{array}{l}\text { Levar o aluno a reconhecer e a estabelecer diferenças entre o texto e } \\
\text { o texto técnico; possibilitar ao aluno redigir textos adequados à sua } \\
\text { realidade profissional; levar o aluno a redigir textos com correção, } \\
\text { clareza e objetividade. }\end{array}$ \\
\hline 29. Teoria da Administração & $\begin{array}{l}\text { Ao final do curso, os participantes deverão apresentar } \\
\text { conhecimentos básicos sobre a criação, planejamento, operação e } \\
\text { controle das organizações (produtoras de bens e prestadoras de } \\
\text { serviços) e sobre as funções maiores da administração. }\end{array}$ \\
\hline 30. Teoria Econômica I & $\begin{array}{l}\text { Apresentar ao aluno conceitos de micro e macroeconomia, visando } \\
\text { familiarizá-lo com o instrumental analítico básico dessas áreas. }\end{array}$ \\
\hline
\end{tabular}




\begin{tabular}{|c|c|}
\hline DISCIPLINAS OPTATIVAS & OBJETIVOS \\
\hline 1. Análise de Liquidez & $\begin{array}{l}\text { Apresentar a base conceitual necessária e a análise de } \\
\text { Capital de Giro das empresas observando o impacto no risco } \\
\text { e retorno de suas atividades. }\end{array}$ \\
\hline 2. Avaliação de Ativos & $\begin{array}{l}\text { Desenvolver os conceitos e técnicas contábeis e financeiras } \\
\text { de avaliação de diferentes ativos - empresas, ações, títulos } \\
\text { de renda fixa, obrigações e recursos naturais exauríveis. }\end{array}$ \\
\hline 3. Banco de Dados & $\begin{array}{l}\text { Utilizar gerenciadores de banco de dados para } \\
\text { microcomputadores na solução de problemas e elaboração } \\
\text { de informações relacionadas com o processo de } \\
\text { planejamento e controle econômico-financeiro. }\end{array}$ \\
\hline 4. Contabilidade e Responsabilidade Social & $\begin{array}{l}\text { Identificar e discutir os aspectos econômico e financeiro das } \\
\text { ações que refletem a responsabilidade social das } \\
\text { organizações, bem como, avaliar a influência destas no } \\
\text { desempenho das companhias. }\end{array}$ \\
\hline 5. Contabilidade Rural & $\begin{array}{l}\text { Abordar conceitos e técnicas contábeis aplicáveis as } \\
\text { atividades rurais (agrícolas, pecuárias e agroindustriais), } \\
\text { proporcionando ao aluno uma visão prática do tratamento } \\
\text { contábil dos elementos da empresa rural, bem como das } \\
\text { técnicas de gestão empresarial. }\end{array}$ \\
\hline 6. Contabilometria & $\begin{array}{l}\text { Aprendizagem e aplicação de instrumental quantitativo que } \\
\text { melhore a qualidade ou possibilite a elaboração de } \\
\text { informações de caráter contábil, necessárias aos processos de } \\
\text { avaliação, planejamento e controle econômico-financeiro. }\end{array}$ \\
\hline $\begin{array}{l}\text { 7. Controladoria e Risco de Instituições } \\
\text { Financeiras }\end{array}$ & $\begin{array}{l}\text { Abordar os principais os modelos de controle e avaliação de } \\
\text { risco das principais operações das instituições financeiras, } \\
\text { descrever os produtos financeiros, seus resultados e critérios } \\
\text { de controle gerencial, abordar, também, o estudo do risco } \\
\text { das instituições financeiras incorporando sua mensuração } \\
\text { aos resultados operacionais levantados. }\end{array}$ \\
\hline $\begin{array}{l}\text { 8. Práticas de governança Corporativa e } \\
\text { Informações Contábeis }\end{array}$ & $\begin{array}{l}\text { Fornecer subsídios ao entendimento do papel da Governança } \\
\text { Corporativa no mundo empresarial atual, vendo-a como um } \\
\text { "conjunto de mecanismos de incentivo e controle que visam } \\
\text { harmonizar a relação entre acionistas e gestores pela redução } \\
\text { dos custos de agência, numa situação de separação da } \\
\text { propriedade e controle". }\end{array}$ \\
\hline 9. Tópicos de Contabilidade Internacional & $\begin{array}{l}\text { Conduzir o aluno à reflexão sobre o escopo da Contabilidade } \\
\text { no âmbito internacional, discutindo os principais temas sobre } \\
\text { o assunto, visando uma análise comparativa entre as normas } \\
\text { nacionais, internacionais e norte-americanas. }\end{array}$ \\
\hline $\begin{array}{l}\text { 10. Tópicos de Informática aplicados à } \\
\text { Contabilidade }\end{array}$ & $\begin{array}{l}\text { Introduzir aos alunos de contabilidade conceitos de Sistemas } \\
\text { de Informações Gerenciais com objetivo de melhorar o } \\
\text { processo decisório dos gestores. }\end{array}$ \\
\hline
\end{tabular}




\section{APÊNDICE B - Questionário geral de estilos das disciplinas}

Marque um "X" na alternativa que melhor caracteriza a disciplina ministrada:

Disciplina:

1- Mais Ativa $\quad$ ( ) Mais Reflexiva ( )

Ativa: Predominância de discussões e aplicações práticas, experimentos e trabalhos em grupos.

Reflexiva: Predominância de reflexões nos assuntos antes das discussões e aplicações práticas e trabalhos individuais.

\section{2- Mais Sensorial ( ) Mais Intuitiva ( )}

Sensorial: Predominância de resolução de problemas com procedimentos bem estabelecidos, com memorização e trabalhos experimentais.

Intuitiva: Predominância de fórmulas matemáticas, abstrações e inovações, com pouca memorização e poucas repetições.

\section{3- Mais Visual ( ) Mais Verbal ( )}

Visual: Predominância de aulas mais simbólicas (gráficos, filmes, quadros, diagramas etc.).

Verbal: Predominância de aula mais escrita e falada.

\section{4- Mais Seqüencial ( ) Mais Global ( )}

Sequiencial: Predominância de resolução de problemas por meio de etapas graduais e lógicas.

Global: Predominância de resolução de problemas a partir da visão global e de forma aleatória. 


\section{APÊNDICE C - Disciplinas, estilos e métodos}

\begin{tabular}{|c|c|c|c|c|}
\hline $\begin{array}{c}\text { DISCIPLINAS } \\
\text { OBRIGATÓRIAS }\end{array}$ & $\begin{array}{l}\text { ESTILOS DAS } \\
\text { DISCIPLINAS }\end{array}$ & \multicolumn{2}{|c|}{$\begin{array}{l}\text { ESTILOS DOS } \\
\text { PROFESSORES } \\
\end{array}$} & $\begin{array}{c}\text { MÉTODOS } \\
\text { UTILIZADOS }\end{array}$ \\
\hline $\begin{array}{l}\text { 1. Análise das Demonstrações } \\
\text { Contábeis }\end{array}$ & $\begin{array}{c}\text { ativa } \\
\text { intuitiva } \\
\text { visual } \\
\text { seqüencial }\end{array}$ & $\begin{array}{c}\text { ativo } \\
\text { sensorial } \\
\text { verbal } \\
\text { seqüencial }\end{array}$ & $\begin{array}{c}\text { reflexivo } \\
\text { intuitivo } \\
\text { verbal } \\
\text { global }\end{array}$ & $\begin{array}{l}\text { Aulas expositivas, } \\
\text { com exercícios dentro } \\
\text { e fora da sala de aula, } \\
\text { discussão de casos } \\
\text { práticos. }\end{array}$ \\
\hline 2. Análise de Custos & $\begin{array}{l}\text { reflexiva } \\
\text { sensorial } \\
\text { visual } \\
\text { seqüencial }\end{array}$ & $\begin{array}{l}\text { reflexivo } \\
\text { intuitivo } \\
\text { visual } \\
\text { seqüencial }\end{array}$ & $\begin{array}{c}\text { ativo } \\
\text { sensorial } \\
\text { verbal } \\
\text { seqüencial }\end{array}$ & $\begin{array}{l}\text { Exposição de } \\
\text { conceitos, resolução } \\
\text { de exercícios e } \\
\text { desenvolvimento de } \\
\text { casos tanto em sala de } \\
\text { aula quanto fora. } \\
\end{array}$ \\
\hline 3. Análise de Sistemas Contábeis & $\begin{array}{l}\text { reflexiva } \\
\text { sensorial } \\
\text { visual } \\
\text { global }\end{array}$ & \multicolumn{2}{|c|}{$\begin{array}{l}\text { reflexivo } \\
\text { intuitivo } \\
\text { verbal } \\
\text { global }\end{array}$} & $\begin{array}{l}\text { Aulas expositivas, } \\
\text { com exercícios dentro } \\
\text { e fora da sala de aula, } \\
\text { discussão de casos } \\
\text { práticos. }\end{array}$ \\
\hline 4. Contabilidade Avançada & $\begin{array}{l}\text { ativa } \\
\text { sensorial } \\
\text { verbal } \\
\text { global }\end{array}$ & $\begin{array}{l}\text { reflexivo } \\
\text { intuitivo } \\
\text { visual } \\
\text { global }\end{array}$ & $\begin{array}{c}\text { reflexivo } \\
\text { intuitivo } \\
\text { verbal } \\
\text { global }\end{array}$ & $\begin{array}{l}\text { Aulas expositivas, } \\
\text { com exercícios dentro } \\
\text { e fora da sala de aula, } \\
\text { discussão de casos } \\
\text { práticos. }\end{array}$ \\
\hline 5. Contabilidade de Custos & $\begin{array}{l}\text { reflexiva } \\
\text { sensorial } \\
\text { verbal } \\
\text { sequiencial }\end{array}$ & $\begin{array}{l}\text { reflexivo } \\
\text { intuitivo } \\
\text { visual } \\
\text { seqüencial }\end{array}$ & $\begin{array}{c}\text { ativo } \\
\text { sensorial } \\
\text { verbal } \\
\text { seqüencial }\end{array}$ & $\begin{array}{l}\text { Aulas expositivas e } \\
\text { exercícios. }\end{array}$ \\
\hline 6. Contabilidade Governamental & $\begin{array}{l}\text { reflexiva } \\
\text { sensorial } \\
\text { visual } \\
\text { seqüencial }\end{array}$ & \multicolumn{2}{|c|}{$\begin{array}{c}\text { ativo } \\
\text { intuitivo } \\
\text { visual } \\
\text { seqüencial }\end{array}$} & $\begin{array}{l}\text { Aulas expositivas, } \\
\text { com exercícios dentro } \\
\text { e fora da sala de aula, } \\
\text { discussão de casos } \\
\text { práticos. }\end{array}$ \\
\hline 7. Contabilidade Intermediária & $\begin{array}{l}\text { reflexiva } \\
\text { racional } \\
\text { verbal } \\
\text { seqüencial }\end{array}$ & $\begin{array}{l}\text { reflexivo } \\
\text { sensorial } \\
\text { verbal } \\
\text { sequiencial }\end{array}$ & $\begin{array}{c}\text { reflexivo } \\
\text { intuitivo } \\
\text { verbal } \\
\text { global }\end{array}$ & $\begin{array}{l}\text { Aulas expositivas, } \\
\text { com exercícios dentro } \\
\text { e fora da sala de aula, } \\
\text { discussão de casos } \\
\text { práticos. }\end{array}$ \\
\hline 8. Contabilidade Introdutória I & $\begin{array}{c}\text { ativa } \\
\text { racional } \\
\text { verbal } \\
\text { seqüencial }\end{array}$ & $\begin{array}{l}\text { reflexivo } \\
\text { sensorial } \\
\text { verbal } \\
\text { seqüencial }\end{array}$ & $\begin{array}{l}\text { ativo } \\
\text { sensorial } \\
\text { visual } \\
\text { global }\end{array}$ & $\begin{array}{l}\text { Aulas expositivas com } \\
\text { exercícios de fixação; } \\
\text { metodologia de } \\
\text { balanços sucessivos. }\end{array}$ \\
\hline 9. Contabilidade Introdutória II & $\begin{array}{l}\text { reflexiva } \\
\text { sensorial } \\
\text { verbal } \\
\text { seqüencial }\end{array}$ & \multicolumn{2}{|c|}{$\begin{array}{c}\text { reflexivo } \\
\text { sensorial } \\
\text { verbal } \\
\text { seqüencial }\end{array}$} & $\begin{array}{l}\text { Aulas expositivas com } \\
\text { exercícios de fixação e } \\
\text { verificação de casos } \\
\text { reais }\end{array}$ \\
\hline 10. Contabilidade Tributária I & $\begin{array}{c}\text { ativa } \\
\text { racional } \\
\text { verbal } \\
\text { seqüencial }\end{array}$ & \multicolumn{2}{|c|}{$\begin{array}{c}\text { ativo } \\
\text { intuitivo } \\
\text { visual } \\
\text { global }\end{array}$} & $\begin{array}{l}\text { Aulas expositivas, } \\
\text { com exercícios dentro } \\
\text { e fora da sala de aula, } \\
\text { discussão de casos } \\
\text { práticos. }\end{array}$ \\
\hline 11. Contabilidade Tributária II & $\begin{array}{l}\text { ativa } \\
\text { racional } \\
\text { verbal } \\
\text { seqüencial }\end{array}$ & \multicolumn{2}{|c|}{$\begin{array}{l}\text { ativo } \\
\text { intuitivo } \\
\text { visual } \\
\text { global }\end{array}$} & $\begin{array}{l}\text { Aulas expositivas, } \\
\text { aplicação e discussão } \\
\text { de exercícios, casos e } \\
\text { trabalhos. }\end{array}$ \\
\hline
\end{tabular}




\begin{tabular}{|c|c|c|c|}
\hline $\begin{array}{c}\text { (continuação...) } \\
\text { DISCIPLINAS } \\
\text { OBRIGATÓRIAS }\end{array}$ & $\begin{array}{l}\text { ESTILOS DAS } \\
\text { DISCIPLINAS }\end{array}$ & $\begin{array}{l}\text { ESTILOS DOS } \\
\text { PROFESSORES }\end{array}$ & $\begin{array}{l}\text { MÉTODOS } \\
\text { UTILIZADOS }\end{array}$ \\
\hline 12. Teoria da Contabilidade & $\begin{array}{c}\text { reflexiva } \\
\text { intuitiva } \\
\text { verbal } \\
\text { global }\end{array}$ & $\begin{array}{c}\text { ativo } \\
\text { intuitivo } \\
\text { visual } \\
\text { global }\end{array}$ & $\begin{array}{l}\text { Aulas expositivas, } \\
\text { com exercícios dentro } \\
\text { e fora da sala de aula, } \\
\text { discussão de casos } \\
\text { práticos. }\end{array}$ \\
\hline $\begin{array}{l}\text { 13. Fundamentos para Análise de } \\
\text { Sistemas }\end{array}$ & $\begin{array}{c}\text { ativa } \\
\text { sensorial } \\
\text { visual } \\
\text { seqüencial }\end{array}$ & $\begin{array}{l}\text { reflexivo } \\
\text { intuitivo } \\
\text { verbal } \\
\text { global }\end{array}$ & $\begin{array}{l}\text { Aulas expositivas e } \\
\text { cooperativas; } \\
\text { exercícios individuais } \\
\text { e coletivos; } \\
\text { estudos de casos. }\end{array}$ \\
\hline 14. Informática Aplicada & $\begin{array}{c}\text { ativa } \\
\text { sensorial } \\
\text { visual } \\
\text { seqüencial }\end{array}$ & $\begin{array}{l}\text { reflexivo } \\
\text { sensorial } \\
\text { visual } \\
\text { global }\end{array}$ & $\begin{array}{l}\text { Aulas expositivas e } \\
\text { cooperativas; aulas } \\
\text { práticas no laboratório } \\
\text { de computação; } \\
\text { exercícios individuais } \\
\text { e coletivos; palestras. }\end{array}$ \\
\hline $\begin{array}{l}\text { 15. Introdução à Probabilidade e à } \\
\text { Estatística I }\end{array}$ & $\begin{array}{l}\text { reflexiva } \\
\text { sensorial } \\
\text { visual } \\
\text { sequiencial }\end{array}$ & $\begin{array}{l}\text { reflexivo } \\
\text { intuitivo } \\
\text { visual } \\
\text { seqüencial }\end{array}$ & $\begin{array}{l}\text { Aulas expositivas e } \\
\text { resolução } \\
\text { exercícios. }\end{array}$ \\
\hline $\begin{array}{l}\text { 16. Introdução à Probabilidade e à } \\
\text { Estatística II }\end{array}$ & $\begin{array}{l}\text { reflexiva } \\
\text { sensorial } \\
\text { visual } \\
\text { sequiencial }\end{array}$ & $\begin{array}{l}\text { reflexivo } \\
\text { intuitivo } \\
\text { visual } \\
\text { seqüencial }\end{array}$ & $\begin{array}{ll}\text { Aulas expositivas } & \mathrm{e} \\
\text { resolução } & \mathrm{de} \\
\text { exercícios. } & \end{array}$ \\
\hline $\begin{array}{l}\text { 17. Complementos de Matemática } \\
\text { para Contabilidade }\end{array}$ & $\begin{array}{l}\text { reflexiva } \\
\text { sensorial } \\
\text { verbal } \\
\text { seqüencial }\end{array}$ & $\begin{array}{l}\text { reflexivo } \\
\text { intuitivo } \\
\text { visual } \\
\text { seqüencial }\end{array}$ & $\begin{array}{l}\text { Aulas expositivas de } \\
\text { teoria e exercícios. }\end{array}$ \\
\hline 18. Auditoria e Perícia & $\begin{array}{c}\text { ativa } \\
\text { sensorial } \\
\text { visual } \\
\text { seqüencial }\end{array}$ & $\begin{array}{c}\text { ativo } \\
\text { intuitivo } \\
\text { visual } \\
\text { seqüencial }\end{array}$ & $\begin{array}{l}\text { Aulas expositivas, } \\
\text { análise e discussão de } \\
\text { textos, estudo de casos } \\
\text { e exercícios. }\end{array}$ \\
\hline 19. Comunicação Oral e Escrita & $\begin{array}{l}\text { reflexiva } \\
\text { intuitiva } \\
\text { verbal } \\
\text { seqüencial } \\
\end{array}$ & $\begin{array}{l}\text { reflexiva } \\
\text { sensorial } \\
\text { verbal } \\
\text { seqüencial } \\
\end{array}$ & $\begin{array}{l}\text { Aulas expositivas, } \\
\text { aulas práticas e } \\
\text { debates. }\end{array}$ \\
\hline 20. Direito Empresarial & $\begin{array}{l}\text { reflexiva } \\
\text { intuitiva } \\
\text { verbal } \\
\text { global }\end{array}$ & $\begin{array}{l}\text { reflexivo } \\
\text { intuitivo } \\
\text { visual } \\
\text { global }\end{array}$ & $\begin{array}{l}\text { Aulas teóricas, aulas } \\
\text { práticas, seminários, } \\
\text { trabalhos de campo, } \\
\text { leituras programadas } \\
\text { etc. }\end{array}$ \\
\hline $\begin{array}{l}\text { 21. Economia Brasileira para } \\
\text { Administradores }\end{array}$ & $\begin{array}{c}\text { ativa } \\
\text { sensorial } \\
\text { verbal } \\
\text { seqüencial }\end{array}$ & $\begin{array}{c}\text { ativo } \\
\text { sensorial } \\
\text { verbal } \\
\text { seqüencial }\end{array}$ & $\begin{array}{l}\text { (não há descrição de } \\
\text { métodos para essa } \\
\text { disciplina) }\end{array}$ \\
\hline 22. Estratégia Financeira & $\begin{array}{l}\text { reflexiva } \\
\text { intuitiva } \\
\text { visual } \\
\text { seqüencial }\end{array}$ & $\begin{array}{c}\text { ativo } \\
\text { sensorial } \\
\text { visual } \\
\text { seqüencial }\end{array}$ & $\begin{array}{l}\text { Aulas expositivas, } \\
\text { exercícios e trabalhos. }\end{array}$ \\
\hline 23. Introdução à Sociologia & $\begin{array}{l}\text { reflexiva } \\
\text { sensorial } \\
\text { verbal } \\
\text { seqüencial }\end{array}$ & $\begin{array}{c}\text { ativo } \\
\text { intuitivo } \\
\text { visual } \\
\text { seqüencial }\end{array}$ & $\begin{array}{l}\text { Aulas expositivas e } \\
\text { seminários. } \\
\text { (continua...) }\end{array}$ \\
\hline
\end{tabular}




\begin{tabular}{|c|c|c|c|c|}
\hline $\begin{array}{c}\text { (continuação...) } \\
\text { DISCIPLINAS } \\
\text { OBRIGATÓRIAS }\end{array}$ & $\begin{array}{l}\text { ESTILOS DAS } \\
\text { DISCIPLINAS }\end{array}$ & \multicolumn{2}{|c|}{$\begin{array}{l}\text { ESTILOS DOS } \\
\text { PROFESSORES }\end{array}$} & $\begin{array}{c}\text { MÉTODOS } \\
\text { UTILIZADOS }\end{array}$ \\
\hline 24. Legislação Social & $\begin{array}{c}\text { ativa } \\
\text { sensorial } \\
\text { verbal } \\
\text { global }\end{array}$ & \multicolumn{2}{|c|}{$\begin{array}{c}\text { reflexivo } \\
\text { sensorial } \\
\text { visual } \\
\text { global } \\
\end{array}$} & $\begin{array}{l}\text { Aulas expositivas } \mathrm{e} \\
\text { trabalhos práticos. }\end{array}$ \\
\hline 25. Matemática Financeira & $\begin{array}{l}\text { reflexiva } \\
\text { sensorial } \\
\text { visual } \\
\text { seqüencial } \\
\end{array}$ & \multicolumn{2}{|c|}{$\begin{array}{c}\text { ativo } \\
\text { sensorial } \\
\text { visual } \\
\text { seqüencial } \\
\end{array}$} & $\begin{array}{lr}\text { Aulas expositivas } & \mathrm{e} \\
\text { resolução } & \mathrm{de} \\
\text { exercícios. } & \end{array}$ \\
\hline 26. Mercado Financeiro I & $\begin{array}{c}\text { ativa } \\
\text { sensorial } \\
\text { verbal } \\
\text { seqüencial } \\
\end{array}$ & $\begin{array}{c}\text { reflexivo } \\
\text { intuitivo } \\
\text { verbal } \\
\text { global } \\
\end{array}$ & $\begin{array}{l}\text { reflexivo } \\
\text { intuitivo } \\
\text { visual } \\
\text { global } \\
\end{array}$ & $\begin{array}{lr}\text { Exposição } & \text { teórica; } \\
\text { exemplos } & \text { práticos; } \\
\text { soluções } & \text { de } \\
\text { problemas. } & \\
\end{array}$ \\
\hline $\begin{array}{l}\text { 27. Planejamento Estratégico e } \\
\text { Orçamento Empresarial }\end{array}$ & $\begin{array}{l}\text { reflexiva } \\
\text { sensorial } \\
\text { verbal } \\
\text { seqüencial }\end{array}$ & \multicolumn{2}{|c|}{$\begin{array}{c}\text { ativo } \\
\text { intuitivo } \\
\text { visual } \\
\text { global }\end{array}$} & $\begin{array}{l}\text { Aulas expositivas, } \\
\text { com exercícios dentro } \\
\text { e fora da sala de aula, } \\
\text { discussão de casos } \\
\text { práticos. }\end{array}$ \\
\hline 28. Português Instrumental & $\begin{array}{l}\text { reflexiva } \\
\text { sensorial } \\
\text { verbal } \\
\text { sequiencial }\end{array}$ & \multicolumn{2}{|c|}{$\begin{array}{l}\text { reflexivo } \\
\text { sensorial } \\
\text { verbal } \\
\text { seqüencial }\end{array}$} & $\begin{array}{l}\text { Aulas teóricas; aulas } \\
\text { práticas; debates e } \\
\text { outros. }\end{array}$ \\
\hline 29. Teoria da Administração & $\begin{array}{l}\text { reflexiva } \\
\text { intuitiva } \\
\text { visual } \\
\text { sequiencial }\end{array}$ & \multicolumn{2}{|c|}{$\begin{array}{l}\text { ativo } \\
\text { sensorial } \\
\text { visual } \\
\text { global }\end{array}$} & $\begin{array}{l}\text { Preleções dialogadas, } \\
\text { trabalho teórico- } \\
\text { prático de pesquisa, } \\
\text { estudos de casos e } \\
\text { argüições. }\end{array}$ \\
\hline 30. Teoria Econômica I & $\begin{array}{l}\text { reflexiva } \\
\text { intuitiva } \\
\text { visual } \\
\text { seqüencial }\end{array}$ & \multicolumn{2}{|c|}{$\begin{array}{l}\text { ativo } \\
\text { sensorial } \\
\text { visual } \\
\text { sequiencial }\end{array}$} & $\begin{array}{l}\text { (não há descrição de } \\
\text { métodos para essa } \\
\text { disciplina) }\end{array}$ \\
\hline
\end{tabular}




\begin{tabular}{|c|c|c|c|c|}
\hline $\begin{array}{c}\text { DISCIPLINAS } \\
\text { OPTATIVAS }\end{array}$ & $\begin{array}{l}\text { ESTILOS DAS } \\
\text { DISCIPLINAS }\end{array}$ & \multicolumn{2}{|c|}{$\begin{array}{c}\text { ESTILOS DOS } \\
\text { PROFESSORES }\end{array}$} & $\begin{array}{c}\text { MÉTODOS } \\
\text { UTILIZADOS } \\
\end{array}$ \\
\hline 1. Análise de Liquidez & $\begin{array}{c}\text { reflexiva } \\
\text { intuitiva } \\
\text { verbal } \\
\text { global } \\
\end{array}$ & $\begin{array}{l}\text { reflexivo } \\
\text { intuitivo } \\
\text { visual } \\
\text { global } \\
\end{array}$ & $\begin{array}{c}\text { ativo } \\
\text { sensorial } \\
\text { visual } \\
\text { seqüencial } \\
\end{array}$ & $\begin{array}{l}\text { Aulas expositivas, } \\
\text { exercícios e seminários. }\end{array}$ \\
\hline 2. Avaliação de Ativos & $\begin{array}{c}\text { ativa } \\
\text { sensorial } \\
\text { visual } \\
\text { seqüencial } \\
\end{array}$ & $\begin{array}{l}\text { reflexivo } \\
\text { intuitivo } \\
\text { verbal } \\
\text { global } \\
\end{array}$ & $\begin{array}{l}\text { reflexivo } \\
\text { intuitivo } \\
\text { visual } \\
\text { global } \\
\end{array}$ & $\begin{array}{l}\text { Exposição teórica, } \\
\text { exemplos práticos } \\
\text { soluções de exercícios. }\end{array}$ \\
\hline 3. Banco de Dados & $\begin{array}{l}\text { ativa } \\
\text { sensorial } \\
\text { visual } \\
\text { seqüencial }\end{array}$ & \multicolumn{2}{|c|}{$\begin{array}{c}\text { reflexivo } \\
\text { sensorial } \\
\text { visual } \\
\text { global }\end{array}$} & $\begin{array}{l}\text { Aulas expositivas e } \\
\text { cooperativas, aulas } \\
\text { práticas no laboratório de } \\
\text { computação, exercícios } \\
\text { individuais e coletivos, } \\
\text { palestras e apresentações. }\end{array}$ \\
\hline $\begin{array}{l}\text { 4. Contabilidade e } \\
\text { Responsabilidade Social }\end{array}$ & $\begin{array}{l}\text { ativa } \\
\text { sensorial } \\
\text { verbal } \\
\text { global } \\
\end{array}$ & \multicolumn{2}{|c|}{$\begin{array}{l}\text { reflexivo } \\
\text { sensorial } \\
\text { verbal } \\
\text { seqüencial } \\
\end{array}$} & $\begin{array}{l}\text { Estudos de casos } \mathrm{e} \\
\text { discussões conjuntas. }\end{array}$ \\
\hline 5. Contabilidade Rural & $\begin{array}{l}\text { ativa } \\
\text { sensorial } \\
\text { visual } \\
\text { global }\end{array}$ & \multicolumn{2}{|c|}{$\begin{array}{l}\text { reflexivo } \\
\text { sensorial } \\
\text { verbal } \\
\text { seqüencial }\end{array}$} & \begin{tabular}{ll} 
Aulas expositivas, & \multicolumn{2}{c}{, de } \\
desenvolvimento & discussão \\
exercícios, de \\
casos práticos & e \\
seminários. & \\
\end{tabular} \\
\hline 6. Contabilometria & $\begin{array}{c}\text { ativa } \\
\text { sensorial } \\
\text { visual } \\
\text { seqüencial } \\
\end{array}$ & $\begin{array}{c}\text { ativo } \\
\text { intuitivo } \\
\text { visual } \\
\text { seqüencial } \\
\end{array}$ & $\begin{array}{l}\text { reflexivo } \\
\text { intuitivo } \\
\text { visual } \\
\text { seqüencial } \\
\end{array}$ & $\begin{array}{lrr}\text { Aulas } & \text { expositivas, } \\
\text { resolução de exercícios, } \\
\text { utilização de recursos } \\
\text { audiovisuais e seminários. }\end{array}$ \\
\hline $\begin{array}{l}\text { 7. Controladoria e Risco de } \\
\text { Instituições Financeiras }\end{array}$ & $\begin{array}{l}\text { ativa } \\
\text { sensorial } \\
\text { verbal } \\
\text { global }\end{array}$ & \multicolumn{2}{|c|}{$\begin{array}{c}\text { reflexivo } \\
\text { intuitivo } \\
\text { verbal } \\
\text { global }\end{array}$} & $\begin{array}{ll}\text { Exposiçõos } & \text { teóricas, } \\
\text { exemplos } & \text { práticos, } \\
\text { soluções de casos e } \\
\text { problemas. }\end{array}$ \\
\hline $\begin{array}{l}\text { 8. Práticas de Governança } \\
\text { Corporativa e Informações } \\
\text { Contábeis }\end{array}$ & $\begin{array}{l}\text { reflexiva } \\
\text { sensorial } \\
\text { verbal } \\
\text { seqüencial }\end{array}$ & \multicolumn{2}{|c|}{$\begin{array}{l}\text { reflexivo } \\
\text { intuitivo } \\
\text { verbal } \\
\text { global }\end{array}$} & $\begin{array}{l}\text { Discussão e análise de } \\
\text { casos reais, relatórios e } \\
\text { apresentação } \\
\text { relatórios. }\end{array}$ \\
\hline $\begin{array}{l}\text { 9. Tópicos de Contabilidade } \\
\text { Internacional }\end{array}$ & $\begin{array}{c}\text { ativa } \\
\text { sensorial } \\
\text { verbal } \\
\text { seqüencial }\end{array}$ & \multicolumn{2}{|c|}{$\begin{array}{l}\text { reflexivo } \\
\text { sensorial } \\
\text { visual } \\
\text { seqüencial }\end{array}$} & $\begin{array}{l}\text { Aulas expositivas, } \\
\text { desenvolvimento de } \\
\text { exercícios e seminários. }\end{array}$ \\
\hline $\begin{array}{l}\text { 10. Tópicos de Informática } \\
\text { aplicados à Contabilidade }\end{array}$ & $\begin{array}{l}\text { ativa } \\
\text { intuitiva } \\
\text { visual } \\
\text { global }\end{array}$ & \multicolumn{2}{|c|}{$\begin{array}{l}\text { reflexivo } \\
\text { sensorial } \\
\text { visual } \\
\text { global }\end{array}$} & $\begin{array}{l}\text { Aulas expositivas e } \\
\text { cooperativas, aulas } \\
\text { práticas no laboratório de } \\
\text { computação, exercícios } \\
\text { individuais e coletivos. }\end{array}$ \\
\hline
\end{tabular}


ANEXO 
ANEXO A - ILS de Felder-Soloman

Mapeamento dos

Estilos de

Aprendizagem
Escola de Engenharia de São Carlos-USP

(Brasil)

Cadastro Pessoal

Universidade Federal de São Carlos

(Brasil)

Texas A\&M University - College Station

Seus dados são requeridos para poder efetuar a análise estatística.

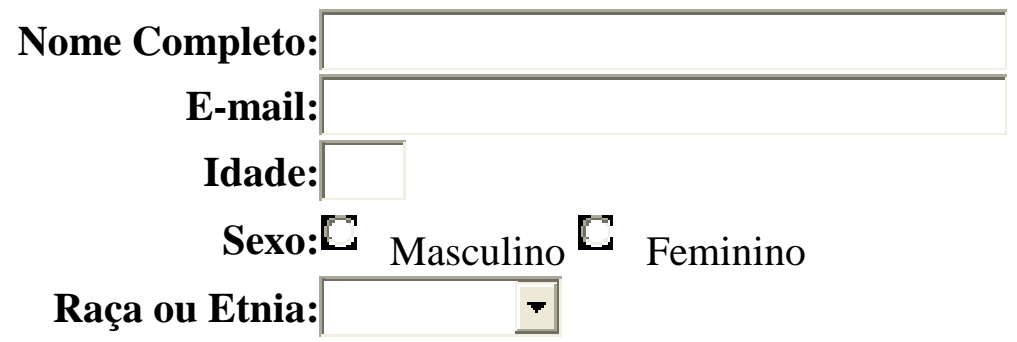

Dados Pessoais

Insira o seu nome completo, email, idade, sexo e raça/etnia. Estes dados servem para agrupar por categorias as pessoas pesquisadas.

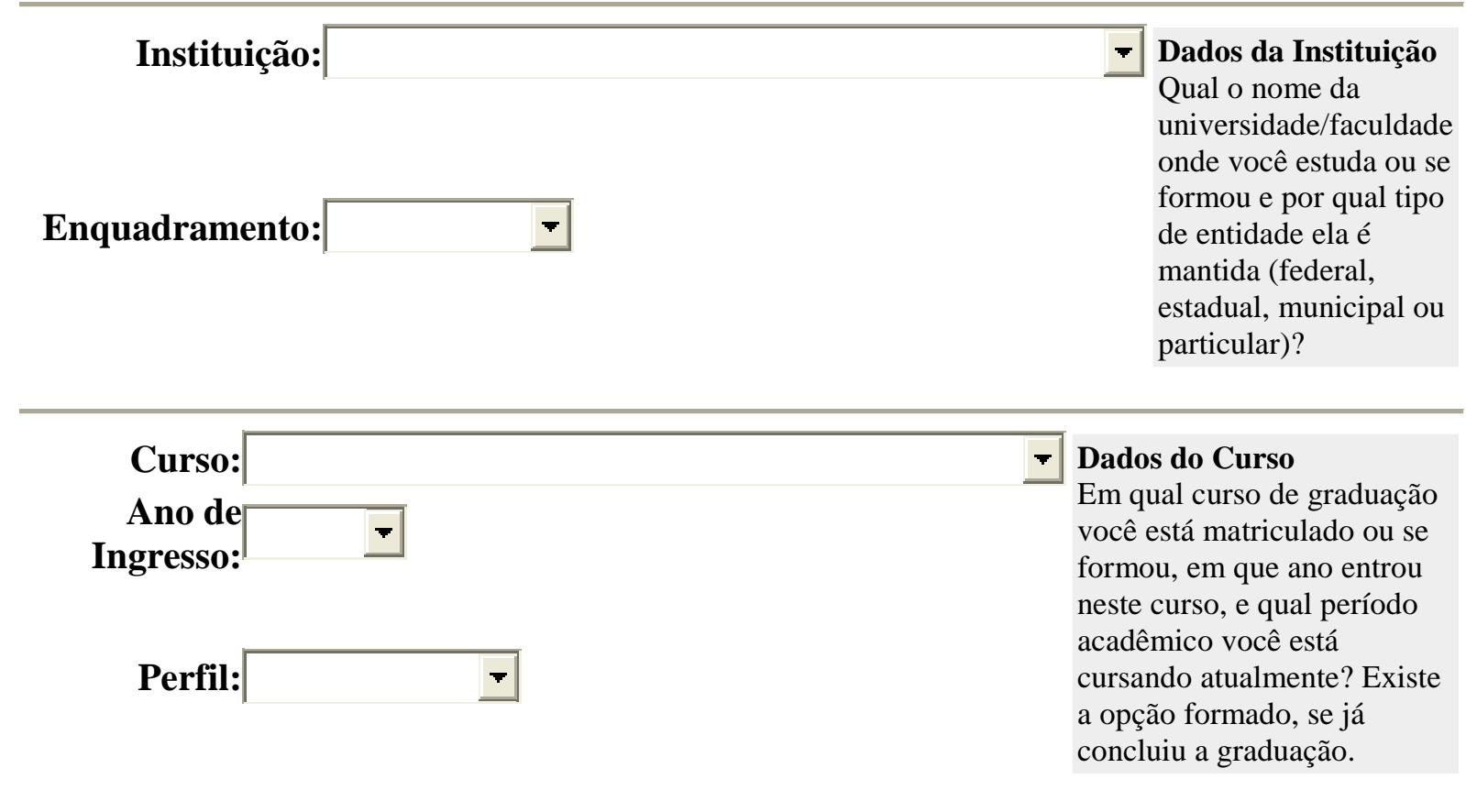

Cadastrar Limpar

Obs.: Todos os campos, exceto a idade, são de preenchimento obrigatório. 
1. Eu compreendo melhor alguma coisa depois de:

C (a) experimentar.

C (b) refletir sobre ela.

\section{Eu me considero:}

(a) realista.

(b) inovador.

3. Quando eu penso sobre o que fiz ontem, é mais provável que aflorem:

(a) figuras.

(b) palavras.

\section{Eu tendo a:}

(a) compreender os detalhes de um assunto, mas a estrutura geral pode ficar imprecisa.

(b) compreender a estrutura geral de um assunto, mas os detalhes podem ficar imprecisos.

\section{Quando estou aprendendo algum assunto novo, me ajuda:}

(a) falar sobre ele.

(b) refletir sobre ele.

\section{Se eu fosse um professor, eu preferiria ensinar uma disciplina:}

(a) que trate com fatos e situações reais.

(b) que trate com idéias e teorias.

\section{Eu prefiro obter novas informações através de:}

C (a) figuras, diagramas, gráficos ou mapas.

(b) instruções escritas ou informações verbais.

\section{Quando eu compreendo:}

(a) todas as partes, consigo entender o todo.

(b) o todo, consigo ver como as partes se encaixam.

9. Em um grupo de estudo, trabalhando um material difícil, eu provavelmente:

(a) tomo a iniciativa e contribuo com idéias.

C (b) assumo uma posição discreta e escuto. 


\section{Acho mais fácil:}

(a) aprender fatos.

(b) aprender conceitos.

\section{Em um livro com uma porção de figuras e desenhos, eu provavelmente:}

(a) observo as figuras e desenhos cuidadosamente.

(b) atento para o texto escrito.

\section{Quando resolvo problemas de matemática, eu:}

(a) usualmente trabalho de maneira a resolver uma etapa de cada vez.

C (b) frequentemente antevejo as soluções, mas tenho que me esforçar muito para conceber as etapas para chegar a elas.

\section{Nas disciplinas que cursei eu:}

(a) em geral fiz amizade com muitos dos colegas.

(b) raramente fiz amizade com muitos dos colegas.

\section{Em literatura de não-ficção, eu prefiro:}

(a) algo que me ensine fatos novos ou me indique como fazer alguma coisa.

(b) algo que me apresente novas idéias para pensar.

\section{Eu gosto de professores:}

(a) que colocam uma porção de diagramas no quadro.

(b) que gastam bastante tempo explicando.

\section{Quando estou analisando uma estória ou novela eu:}

C (a) penso nos incidentes e tento colocá-los juntos para identificar os temas.

C (b) tenho consciência dos temas quando termino a leitura e então tenho que voltar atrás para encontrar os incidentes que os confirmem.

\section{Quando inicio a resolução de uma "tarefa de casa", normalmente eu:}

C (a) começo a trabalhar imediatamente na solução.

C (b) primeiro tento compreender completamente o problema.

\section{Prefiro a idéia do:}
(a) certo.
(b) teórico. 


\section{Relembro melhor:}

(a) o que vejo.

(b) o que ouço.

20. É mais importante para mim que o professor:

C (a) apresente a matéria em etapas seqüenciais claras.

(b) apresente um quadro geral e relacione a matéria com outros assuntos.

\section{Eu prefiro estudar:}

C (a) em grupo.

C (b) sozinho.

22. Eu costumo ser considerado (a):

(a) cuidadoso (a) com os detalhes do meu trabalho.

C (b) criativo (a) na maneira de realizar meu trabalho.

23. Quando busco orientação para chegar a um lugar desconhecido, eu prefiro:

(a) um mapa.

C (b) instruções por escrito.

\section{Eu aprendo:}

(a) num ritmo bastante regular. Se estudar pesado, eu "chego lá".

(b) em saltos. Fico totalmente confuso (a) por algum tempo, e então, repentinamente eu tenho um "estalo".

\section{Eu prefiro primeiro:}

C (a) experimentar as coisas.

(b) pensar sobre como é que eu vou fazer.

\section{Quando estou lendo por lazer, eu prefiro escritores que:}

C (a) explicitem claramente o que querem dizer.

C (b) dizem as coisas de maneira criativa, interessante.

27. Quando vejo um diagrama ou esquema em uma aula, relembro mais facilmente:
C (a) a figura.
(b) o que o professor disse a respeito dela. 
28. Quando considero um conjunto de informações, provavelmente eu:

C (a) presto mais atenção nos detalhes e não percebo o quadro geral.

(b) procuro compreender o quadro geral antes de atentar para os detalhes.

\section{Relembro mais facilmente:}

(a) algo que fiz.

(b) algo sobre o que pensei bastante.

30. Quando tenho uma tarefa para executar, eu prefiro:

(a) dominar uma maneira para a execução da tarefa.

C (b) encontrar novas maneiras para a execução da tarefa.

31. Quando alguém está me mostrando dados, eu prefiro:

(a) diagramas ou gráficos.

(b) texto sumarizando os resultados.

32. Quando escrevo um texto, eu prefiro trabalhar (pensar a respeito ou escrever):

C (a) a parte inicial do texto e avançar ordenadamente.

C (b) diferentes partes do texto e ordená-las depois.

33. Quando tenho que trabalhar em um projeto em grupo, eu prefiro que se faça primeiro:

(a) um debate (brainstorming) em grupo, onde todos contribuem com idéias.

(b) um brainstorming individual, seguido de reunião do grupo para comparar as idéias.

\section{Considero um elogio chamar alguém de:}

(a) sensível.

C (b) imaginativo.

35. Das pessoas que conheço em uma festa, provavelmente eu me recordo melhor:

(a) da sua aparência.

(b) do que elas disseram sobre si mesmas.

36. Quando estou aprendendo um assunto novo, eu prefiro:

C (a) concentrar-me no assunto, aprendendo o máximo possível.

(b) tentar estabelecer conexões entre o assunto e outros a ele relacionados. 
37. Mais provavelmente sou considerado (a):

C (a) expansivo (a).

(b) reservado (a).

38. Prefiro disciplinas que enfatizam:

(a) material concreto (fatos, dados).

C (b) material abstrato (conceitos teorias).

39. Para entretenimento, eu prefiro:

C (a) assistir televisão.

C (b) ler um livro.

40. Alguns professores iniciam suas preleções com um resumo do que irão cobrir. Tais resumos são:

C (a) de alguma utilidade para mim.

C (b) muito úteis para mim.

41. A idéia de fazer o trabalho de casa em grupo, com a mesma nota para todos do grupo:

C (a) me agrada.

(b) não me agrada.

42. Quando estou fazendo cálculos longos:

C (a) tendo a repetir todos os passos e conferir meu trabalho cuidadosamente.

(b) acho cansativo conferir o meu trabalho e tenho que me esforçar para fazê-lo.

43. Tendo a descrever os lugares onde estive:

(a) com facilidade e com bom detalhamento.

C (b) com dificuldade e sem detalhamento.

\section{Quando estou resolvendo problemas em grupo, mais provavelmente eu:}

C (a) penso nas etapas do processo de solução.

(b) penso nas possíveis conseqüências, ou sobre aplicações da solução para uma ampla faixa de áreas. 